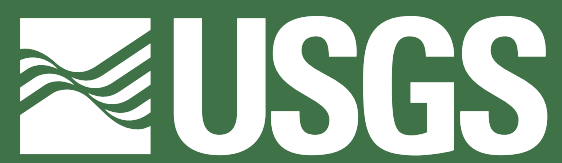

science for a changing world

In cooperation with the

Massachusetts Department of Environmental Protection

Simulated Effects of the 2003 Permitted

Withdrawals and Water-Management

Alternatives on Reservoir Storage and Firm

Yields of Three Surface-Water Supplies,

Ipswich River Basin, Massachusetts

Scientific Investigations Report 2004-5122

Revised 2006

U.S. Department of the Interior

U.S. Geological Survey 
This revised report corrects errors found in the drainage areas directly contributing to the Lynn and Peabody water-supply reservoirs. These corrections affected the simulated water-supply yields of each of the systems examined, which are updated in this report. 
Simulated Effects of the 2003 Permitted Withdrawals and Water-Management Alternatives on Reservoir Storage and Firm Yields of Three Surface-Water Supplies, Ipswich River Basin, Massachusetts

By Phillip J. Zarriello 


\section{U.S. Department of the Interior \\ Gale A. Norton, Secretary}

\section{U.S. Geological Survey Charles G. Groat, Director}

\section{U.S. Geological Survey, Reston, Virginia: 2004 \\ Revised 2006}

For sale by U.S. Geological Survey, Information Services

Box 25286, Denver Federal Center

Denver, CO 80225

For more information about the USGS and its products:

Telephone: 1-888-ASK-USGS

World Wide Web: http://www.usgs.gov/

Any use of trade, product, or firm names in this publication is for descriptive purposes only and does not imply endorsement by the U.S. Government.

Although this report is in the public domain, permission must be secured from the individual copyright owners to reproduce any copyrighted materials contained within this report.

Zarriello, P.J., 2004, Simulated effects of the 2003 permitted withdrawals and water-management alternatives on reservoir storage and firm yield of three surface-water supplies, Ipswich River Basin, Massachusetts: U.S. Geological Survey Scientific Investigations Report 2004-5122, Revised 2006, 53 p. 


\section{Contents}

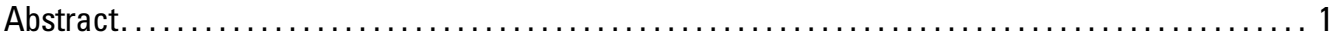

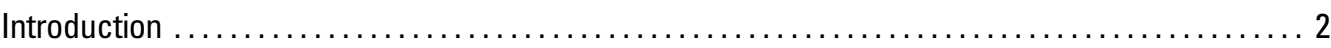

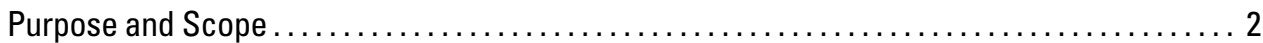

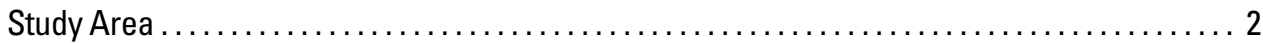

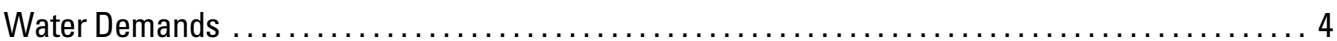

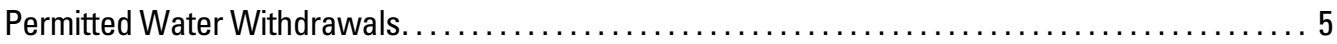

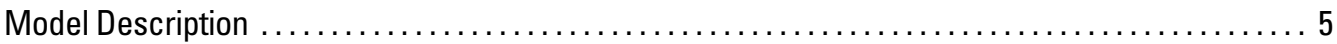

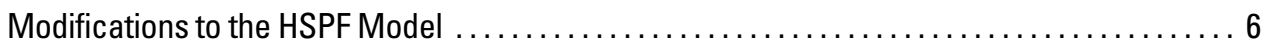

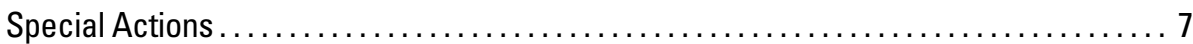

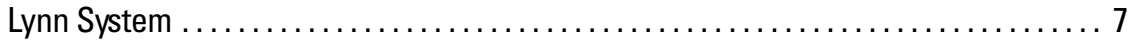

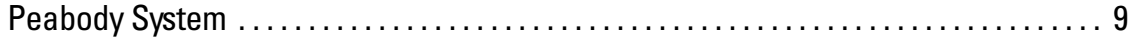

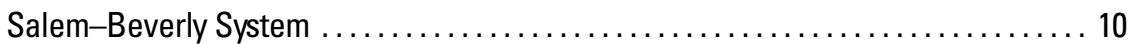

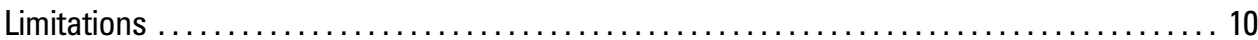

Effects of 2003 Permitted Withdrawals and Water-Management Alternatives on

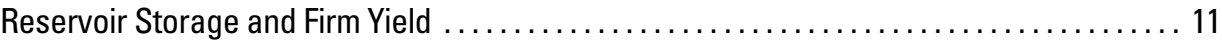

Permitted Withdrawals (FY-IPR1) and Permitted Withdrawals with a

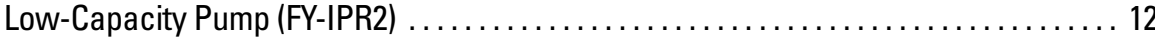

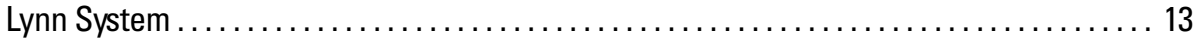

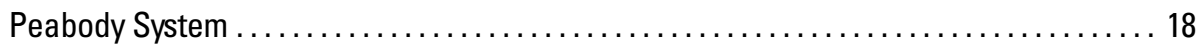

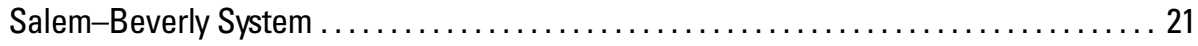

Effects of Alternative Seasonal Streamflow Thresholds on Firm Yield (FY-IPR3). . . . . . . 25

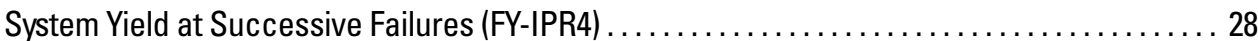

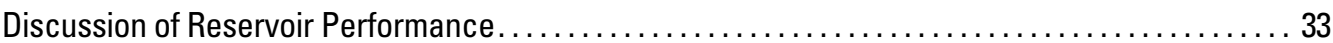

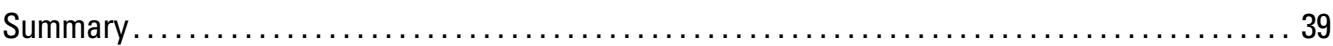

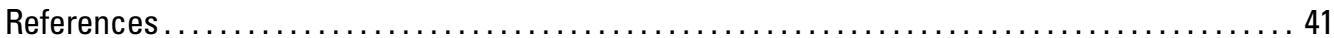

Appendix: Hydrologic Simulation Program-FORTRAN (HSPF) Special Actions Used to

Simulate Withdrawals for Water-Supply Systems $\ldots \ldots \ldots \ldots \ldots \ldots \ldots \ldots \ldots \ldots, \ldots \ldots$

\section{Figures}

1. Map showing principal geographic features, model reach numbers, and locations of the Lynn, Peabody, and Salem-Beverly water-supply systems, Ipswich and

Saugus River Basins, Massachusetts

2-4. Graphs showing examples of withdrawals limited by Hydrologic Simulation

Program-FORTRAN (HSPF) special actions under 2003 permitted withdrawals:

2. Lynn water-supply system from the $A$, Saugus River under the Instream

Flow Incremental Methodology (IFIM) recommended flows and the

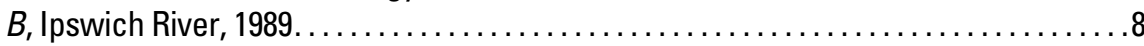

3. Peabody water-supply system, Ipswich River, $1989 \ldots \ldots \ldots \ldots \ldots \ldots \ldots \ldots \ldots$

4. Salem-Beverly water-supply system, Ipswich River, $1989 \ldots \ldots \ldots \ldots \ldots \ldots \ldots \ldots$ 
5-8. Graphs showing simulation results for Lynn water-supply system under average 1998-2000 demands and 2003 permitted withdrawals from the Ipswich River and Instream Flow Incremental Methodology (IFIM) recommended flow for the Saugus River, 1961-95:

5. Daily mean reservoir storage $A$, hydrographs and $B$, duration curves $\ldots \ldots \ldots \ldots 13$

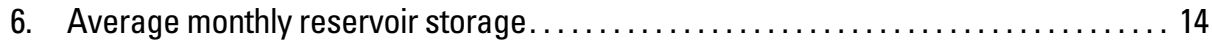

7. Withdrawal-duration curves from the Ipswich and Saugus Rivers $\ldots \ldots \ldots \ldots \ldots 15$

8. Daily mean streamflow-duration curves at the intake locations on the

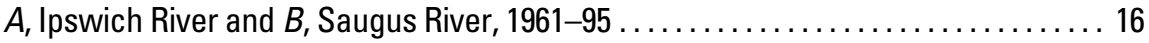

9. Graph showing daily mean reservoir storage simulated at firm-yield demand rates under 2003 permitted withdrawals and under the same streamflow criteria with a hypothetical low-capacity pump, 1961-95.

10-13. Graphs showing simulation results for Peabody water-supply system under average 1998-2000 demands and 2003 permitted withdrawals, 1961-95:

10. Daily mean reservoir storage $A$, hydrographs and $B$, duration curves $\ldots \ldots \ldots \ldots 19$

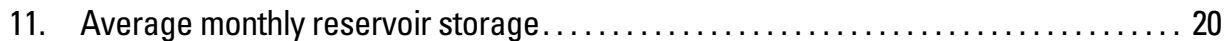

12. Withdrawal-duration curves from the Ipswich River $\ldots \ldots \ldots \ldots \ldots \ldots \ldots \ldots \ldots \ldots \ldots \ldots$

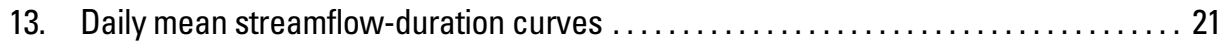

14. Graph showing daily mean reservoir storage simulated at firm-yield demand rates under 2003 permitted withdrawals and 2003 permitted withdrawals with a hypothetical lowcapacity pump, Peabody water-supply system, 1961-95.

15-18. Graphs showing simulation results for Salem-Beverly water-supply system under average 1998-2000 demands and 2003 permitted withdrawals, 1961-95:

15. Daily mean reservoir storage $A$, hydrographs and $B$, duration curves $\ldots \ldots \ldots \ldots 23$

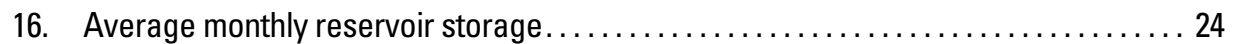

17. Withdrawal-duration curves from the Ipswich River $\ldots \ldots \ldots \ldots \ldots \ldots \ldots \ldots \ldots \ldots \ldots \ldots \ldots \ldots \ldots$

18. Daily mean streamflow-duration curves at the Ipswich River ............... 25

19-27. Graphs showing:

19. Daily mean reservoir storage simulated at firm-yield demand rates under 2003 permitted withdrawals and 2003 permitted withdrawals with a hypothetical low-capacity pump, Salem-Beverly water-supply system, $1961-95 \ldots \ldots \ldots \ldots .26$

20. Changes in firm yield in response to changes in the seasonal streamflow threshold in the Ipswich River for $A$, Lynn; $B$, Peabody; and $C$, Salem-Beverly water-supply systems.

21. Daily mean reservoir storage $A$, hydrographs and $B$, duration curves simulated at withdrawal rates that cause successive failures under the 2003 permitted withdrawals, Lynn water-supply system, 1961-95. ...

22. Daily mean reservoir storage $A$, hydrographs and $B$, duration curves simulated at withdrawal rates that cause successive failures under the 2003 permitted withdrawals, Peabody water-supply system, 1961-95. 31

23. Daily mean reservoir storage $A$, hydrographs and $B$, duration curves simulated at withdrawal rates that cause successive failures under the 2003 permitted withdrawals, Salem-Beverly water-supply system, 1961-95. . .

24. Relation of yield and risk of failure simulated under 2003 permitted withdrawals for the Lynn, Peabody, and Salem-Beverly water-supply systems, 1961-95

25. Simulated average monthly reservoir storage during April (normally highest) and November (normally lowest) at demand rates that cause successive failures under 2003 permitted withdrawals for the $A$, Lynn; $B$, Peabody; and C, Salem-Beverly water-supply systems, 1961-95 .... 
26. Characteristics of total precipitation in the past $60,90,183,365,730$, and 1,095 days and antecedent conditions that led to simulated successive failures under the 2003 permitted withdrawals for the Lynn, Peabody, and

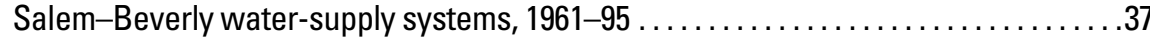

27. Expected recurrence of minimum 90-, 183-, 365-, 730-, and 1,095-day precipitation and the expected recurrence of droughts on the basis of these antecedent conditions that led to simulated successive failures under the 2003 permitted withdrawals for the Lynn, Peabody, and Salem-Beverly watersupply systems, $1961-95$

\section{Tables}

1. Monthly water demands for the Lynn, Peabody, and Salem-Beverly water-supply

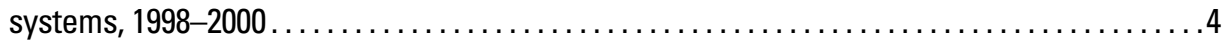

2. Massachusetts Department of Environmental Protection 2003 permitted surface-

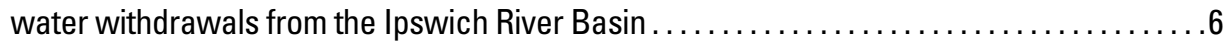

3. Description of Hydrologic Simulation Program-FORTRAN (HSPF) simulations of reservoir storage and yields for the Lynn, Peabody, and Salem-Beverly watersupply systems. ...

4. Identification attributes and organization of output time series simulated by the Hydrologic Simulation Program-FORTRAN (HSPF) for the analysis of reservoir storage and yields of the Lynn, Peabody, and Salem-Beverly water-supply systems . . . . 12

5. Average monthly reservoir storage and number of days during which the mean daily reservoir storage was depleted under average 1998-2000 demands (10.6 million gallons per day) and 2003 permitted withdrawals and under 2003 permitted withdrawals with a hypothetical low-capacity pump, Lynn water-supply system,

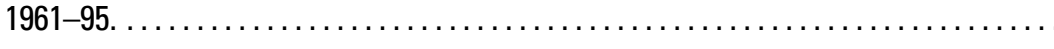

6. Average monthly reservoir storage and number of days during which the mean daily reservoir storage was depleted under average 1998-2000 demands (5.9 million gallons per day) and 2003 permitted withdrawals and under 2003 permitted withdrawals with a hypothetical low-capacity pump, Peabody watersupply system, 1961-95.

7. Average monthly reservoir storage and number of days during which the mean daily reservoir storage was depleted under average 1998-2000 demands (10.1 million gallons per day) and 2003 permitted withdrawals and under 2003 permitted withdrawals with a hypothetical low-capacity pump, Salem-Beverly water-supply system, 1961-95. ...

8. Summary of yield and reservoir performance at successive failures simulated with the Hydrologic Simulation Program-FORTRAN (HSPF) for the Lynn, Peabody, and Salem-Beverly water-supply systems, 1961-95 


\section{Conversion Factors and Abbreviations}

\begin{tabular}{lcl}
\hline Multiply & By & To obtain \\
\hline acre & 0.00405 & square kilometer $\left(\mathrm{km}^{2}\right)$ \\
acre-foot (acre-ft) & $1,233.5$ & cubic meter $\left(\mathrm{m}^{3}\right)$ \\
cubic foot per second $\left(\mathrm{ft}^{3} / \mathrm{s}\right)$ & 0.02832 & cubic meter per second $\left(\mathrm{m}^{3} / \mathrm{s}\right)$ \\
cubic foot per second per square mile & 0.01093 & cubic meter per second per square \\
$\left(\mathrm{ft}^{3} / \mathrm{s} / \mathrm{mi}^{2}\right)$ & & kilometer $\left(\mathrm{m}^{3} / \mathrm{s} / \mathrm{km}^{2}\right)$ \\
mile $(\mathrm{mi})$ & 1.609 & kilometer $(\mathrm{km})$ \\
million gallons $(\mathrm{Mgal})$ & $3,785.4$ & cubic meter $\left(\mathrm{m}^{3}\right)$ \\
million gallons per day $(\mathrm{Mgal} / \mathrm{d})$ & 0.04381 & cubic meter per second $\left(\mathrm{m}^{3} / \mathrm{s}\right)$ \\
million gallons per year $(\mathrm{Mgal} / \mathrm{yr})$ & 0.00120 & cubic meter per second $\left(\mathrm{m}^{3} / \mathrm{s}\right)$ \\
square mile $\left(\mathrm{mi}^{2}\right)$ & 2.590 & square kilometer $\left(\mathrm{km}^{2}\right)$ \\
\hline
\end{tabular}

DSN

HRU

Data Set Number associated with the Watershed Data Management database

Hydrologic response unit

HSPF

Hydrologic Simulation Program-FORTRAN

IDCONS

Constituent identification attribute associated with the Watershed Data

Management database

IDLOCN Location identification attribute associated with the Watershed Data

Management database

IDSCEN Scenario identification attribute associated with the Watershed Data

Management database

IFIM Instream Flow Incremental Methodology

IMPLND HSPF impervious area land element

PERLND HSPF pervious area land element

RCHRES HSPF river or reservoir reach

MDEP

MWRA

Massachusetts Department of Environmental Protection

MFACT

Massachusetts Water Resources Authority

USGS

uci

WDM

Multiplier used to adjust time-series data read from the Watershed Data

Management database

WDMUtil

U.S. Geological Survey

User control input file for Hydrologic Simulation Program-FORTRAN

Watershed Data Management database

Watershed Data Management Utility software 


\title{
Simulated Effects of the 2003 Permitted Withdrawals and Water-Management Alternatives on Reservoir Storage and Firm Yields of Three Surface-Water Supplies, Ipswich River Basin, Massachusetts
}

\author{
By Phillip J. Zarriello
}

\section{Abstract}

The Hydrologic Simulation Program-FORTRAN (HSPF) model of the Ipswich River Basin previously developed by the U.S. Geological Survey was modified to evaluate the effects of the 2003 withdrawal permits and water-management alternatives on reservoir storage and yields of the Lynn, Peabody, and Salem-Beverly water-supply systems. These systems obtain all or part of their water from the Ipswich River Basin. The HSPF model simulated the complex water budgets to the three supply systems, including effects of regulations that restrict withdrawals by the time of year, minimum streamflow thresholds, and the capacity of each system to pump water from the river. The 2003 permits restrict withdrawals from the Ipswich River between November 1 and May 31 to streamflows above a 1.0 cubic foot per second per square mile $\left(\mathrm{ft}^{3} / \mathrm{s} / \mathrm{mi}^{2}\right)$ threshold, to high flows between June 1 and October 31, and to a maximum annual volume. Yields and changes in reservoir storage over the 35-year simulation period (1961-95) were also evaluated for each system with a hypothetical low-capacity pump, alternative seasonal streamflow thresholds, and withdrawals that result in successive failures (depleted storage).

The firm yields, the maximum yields that can be met during a severe drought, calculated for each water-supply system, under the 2003 permitted withdrawals, were 8.59 million gallons per day (Mgal/d) for the Lynn, $3.24 \mathrm{Mgal} / \mathrm{d}$ for the Peabody, and $8.38 \mathrm{Mgal} / \mathrm{d}$ for the Salem-Beverly systems; these yields are 19, 45, and 17 percent less than their average 1998-2000 demands, respectively. The simulations with the same permit restrictions and a hypothetical lowcapacity pump for each system resulted in slightly increased yields for the Lynn and Salem-Beverly systems, but a slightly decreased yield for the Peabody system.
Simulations to evaluate the effects of alternative streamflow thresholds on water supply indicated that firm yields were generally about twice as sensitive to decreases in the November-February or March-May thresholds than to increases in these thresholds. Firm yields were also generally slightly less sensitive to changes in the November-February than to changes in the March-May thresholds in the Peabody and Salem-Beverly water-supply systems. Decreases in the June-October streamflow threshold did not affect any of the system's firm yield.

Simulations of withdrawal rates that resulted in successive near failures during the 1961-95 period indicated the tradeoff between increased yield and risks. The Lynn and SalemBeverly systems were able to meet average 1998-2000 demands after the third near failure. The Peabody system was allowed to nearly fail up to six times. At the sixth near failure, yield increased to $4.60 \mathrm{Mgal} / \mathrm{d}$, or about 78 percent of average 1998 2000 demands. The risk of failure was about 5 percent at the withdrawal rate that caused the sixth near failure in the Peabody system and about 2.5 percent at the withdrawal rate that caused the third near failure in the Lynn and Salem-Beverly systems. Supply systems are at greatest risk of failure from persistent droughts (lasting more than 1 year), but short-term droughts also present risks during the fall and winter when the supply systems are most vulnerable. Uncertainties in model performance, simplification of reservoir systems and their management, and the possibility of droughts of severity greater than simulated in this investigation underscore the fact that the firm yield calculated for each system cannot be considered a withdrawal rate that is absolutely fail-safe. Thus, the consequences of failure are an important consideration in the planning and management of these systems. 


\section{Simulated Effects of the 2003 Permitted Withdrawals and Water-Management Alternatives, Ipswich River Basin, MA}

\section{Introduction}

Public surface-water suppliers in the Commonwealth of Massachusetts are required to provide information on the sustainability of withdrawals under severe drought conditions. The maximum withdrawal rate that can be sustained under these conditions is referred to as the water supply's firm yield or safe yield. The firm yield of a supply reservoir is computed from historical or synthesized water budgets (inflow and outflows to the reservoir) over time and an iterative process of increasing withdrawals until the system's storage is depleted (failure). A water-supply system, which can consist of one or more independent or interconnected reservoirs, is considered to have failed when the available storage of the system is first depleted.

The sustainability of a water-supply system is a function of its storage capacity and the rate of total inflows and outflows to the system. In surface-water-dominated supply systems, the contributing streamflow is often the largest source of water; therefore, a system fails when the contributing streamflow is less than the outflow (including withdrawals) and storage can no longer satisfy demands. Systems that obtain water from the Ipswich River Basin are affected by seasonal restrictions placed on stream withdrawals to maintain aquatic habitat and by the capacity to pump water from the river. These constraints complicate the water budgets for the supply reservoirs and the calculation of the system's firm yield.

The Hydrologic Simulation Program-FORTRAN (HSPF) model of the Ipswich River Basin previously developed by the U.S. Geological Survey (Zarriello and Ries, 2000) was modified to evaluate the storage and yield of three water-supply systems that obtain water from the Ipswich River Basin (Zarriello, 2002). The modified HSPF model simulated reservoir storage under alternative withdrawal constraints, and thus enabled the firm yield to be determined for each system.

Recent changes (2003) to permitted surface-water withdrawals in the Ipswich River Basin by the Massachusetts Department of Environmental Protection (MDEP) prompted a need for further simulations to evaluate the effects of these permits on regional water supplies. In 2003, the U.S. Geological Survey (USGS), in cooperation with the MDEP, began an investigation to evaluate the effects of the 2003 withdrawal permits and management alternatives for three surface-water-supply systems that obtain water from the Ipswich River Basin.

\section{Purpose and Scope}

This report describes the firm yield and changes in reservoir storage of three surface-water-supply systems that obtain water from the Ipswich River Basin-city of Lynn system, city of Peabody system, and the Salem-Beverly Water Supply Board system (referred to hereafter as Lynn, Peabody and Salem-Beverly). The report describes changes made to the existing HSPF model and presents simulation results that describe the effects of the 2003 withdrawal permits and management alternatives including the effect of adding lowcapacity pumps to each system, the effects of alternative streamflow thresholds on firm yield, and the determination of yields and storage characteristics at successive failures. All simulations were run for a 35-year period, from January 1961 through December 1995, except simulations of alternative streamflow thresholds, which were limited to about a 3-year period (January 1964 through February 1967) when the reservoirs first failed.

\section{Study Area}

The Ipswich River Basin in northeastern Massachusetts drains $155 \mathrm{mi}^{2}$ of the Atlantic coastal plain about $20 \mathrm{mi}$ north of Boston (fig. 1). The river empties into the Atlantic Ocean near the southern end of Plum Island. The model area covers the $149 \mathrm{mi}^{2}$ above the Sylvania Dam; below the dam, the river is tidal and was not included in the model. Zarriello and Ries (2000) describe the physical and hydrologic characteristics of the basin, particularly as they relate to the development of the HSPF model. The primary focus of this investigation is the basin area that contributes water to the Lynn, Peabody, and Salem-Beverly water-supply systems. Zarriello (2002) provides a detailed description of these water-supply systems.

Lynn maintains four primary supply reservoirs-Hawkes Pond, Walden Pond, Birch Pond, and Breeds Pond, all of which are outside of the Ipswich River Basin (fig. 1). Collectively, the four reservoirs and a small treated-water reservoir have a usable storage capacity of about 3,940 Mgal (12,080 acre-ft). Water is primarily supplied to the Lynn system by a gravity-fed diversion of the Saugus River and by pumping from the Ipswich River at model reach 18 (fig. 1). The Saugus River drainage area above the Lynn intake is $10.63 \mathrm{mi}^{2}$, and the Ipswich River drainage area above the Lynn intake is $43.8 \mathrm{mi}^{2}$. In addition to these sources, Lynn can purchase water from the Massachusetts Water Resources Authority (MWRA).

Peabody maintains three primary supply reservoirsWinona Pond, Suntaug Lake, Spring Pond and two minor reservoirs-Long Basin and Fountain Pond (fig. 1). Spring Pond, Long Basin, and Fountain Pond are outside of the Ipswich River Basin, but are incorporated into the model in the combined reservoir. These reservoirs, plus other minor storage in the system, have an estimated usable storage of about 1,250 Mgal (3,835 acre-ft). Water is primarily supplied to the Peabody system by pumping from the Ipswich River at model reach 20 (fig. 1). The Ipswich River drainage area above the Peabody intake is $45.6 \mathrm{mi}^{2}$. In addition to this source, Peabody can purchase water from the MWRA. 


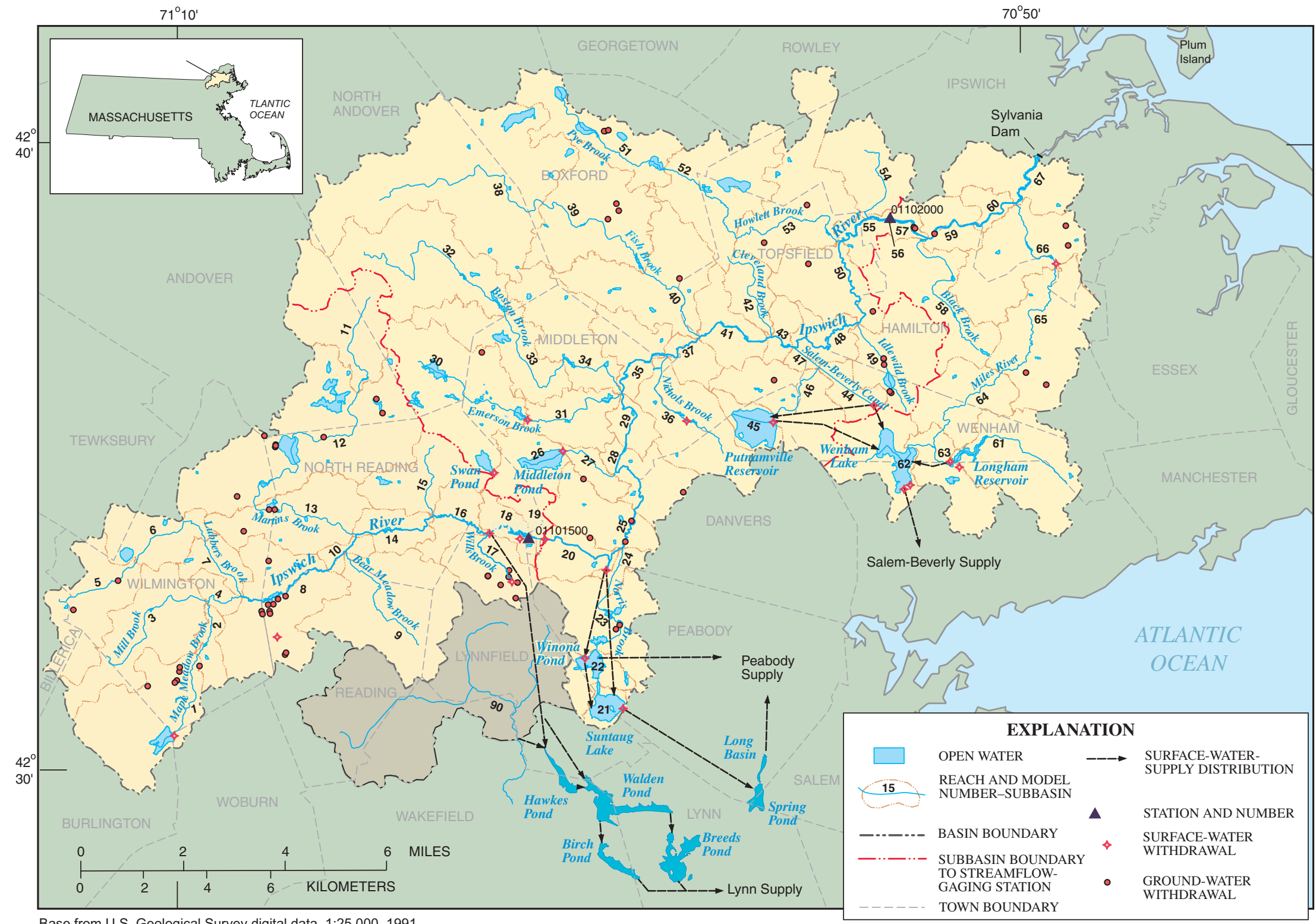

Base from U.S. Geological Survey digital data, 1:25,000, 1991,

Figure 1. Principal geographic features, model reach numbers, and locations of the Lynn, Peabody, and Salem-Beverly water-supply systems, Ipswich and Saugus River Basins, Massachusetts. 


\section{Simulated Effects of the 2003 Permitted Withdrawals and Water-Management Alternatives, Ipswich River Basin, MA}

The Salem-Beverly system supplies water to the cities of Salem, Beverly, and occasionally to the town of Danvers. The Salem-Beverly system has three primary supply reservoirsLongham Reservoir, Putnamville Reservoir, and Wenham Lake (fig. 1). These reservoirs have a usable storage of about 3,550 Mgal (10,910 acre-ft). Water is supplied to the SalemBeverly system by pumping from the Salem-Beverly Canal at model reach 44, which draws water from the Ipswich River at model reach 43 . The Ipswich River drainage area above reach 43 is $100 \mathrm{mi}^{2}$. Direct drainage (4,257 acres) is also an appreciable source of water to the Salem-Beverly reservoirs.

\section{Water Demands}

The analysis of reservoir storage was initially made with average 1998-2000 demands for each system. Total monthly demands reported to the MDEP as a requirement of the Drinking Water Program annual statistical report were used as the seasonal water-withdrawal pattern for the analysis of each system (table 1). The mean of the monthly demands during 1998-2000 were disaggregated into daily values for model simulations.

Total demands for each system reflect the consumptive water use, which is reported on the basis of whether water is used in the treatment process. Raw water is reported when withdrawals include water that is lost during the treatment process (for example, water used to flush filter beds is sent to waste). Finished water is reported when withdrawals include water that is recycled during the treatment process (for example, water used to flush filter beds is returned to the reservoir). Lynn and Salem-Beverly report raw water use and Peabody reports finished water use.

The Lynn system supplied an average of $3,855 \mathrm{Mgal} / \mathrm{yr}$ or about $10.6 \mathrm{Mgal} / \mathrm{d}$ (table 1) during 1998-2000; peak use during the summer was about $2 \mathrm{Mgal} / \mathrm{d}$ (about 20 percent) greater than winter use. Lynn purchased, on average, about 3.1 percent of its water from the MWRA during 1998-2000. The amount of water purchased was generally largest in September and October when reservoir levels were at their seasonal low. Annual demands from the Peabody system averaged $2,145 \mathrm{Mgal} / \mathrm{yr}$ or about $5.9 \mathrm{Mgal} / \mathrm{d}$; peak use during the summer was about $2 \mathrm{Mgal} / \mathrm{d}$ (about 50 percent) greater than winter use. Peabody purchased, on average, about 10 percent of its water from the MWRA during 1998-2000. The percentage of purchased water ranged from zero to nearly 30 percent of the monthly demand and was generally largest in July and August (16.5 percent of demand) and lowest during April and May (3.8 percent of demand). Annual demands from the Salem-Beverly system averaged 3,692 Mgal/yr or about $10.1 \mathrm{Mgal} / \mathrm{d}$; peak use during the summer was about $3 \mathrm{Mgal} / \mathrm{d}$ (40 percent) greater than winter use.
Table 1. Monthly water demands for the Lynn, Peabody, and Salem-Beverly water-supply systems, Massachusetts, 1998-2000.

[Source: Massachusetts Department of Environmental Protection, Drinking Water Program, public-water supply annual statistical report; Mgal, million gallons; Mgal/d, million gallons per day]

\begin{tabular}{|c|c|c|c|c|c|}
\hline \multirow{2}{*}{ Month } & \multicolumn{4}{|c|}{ Total monthly demand, in Mgal } & \multirow{2}{*}{$\begin{array}{l}\text { Average } \\
\text { (Mgal/d }\end{array}$} \\
\hline & 1998 & 1999 & 2000 & Average & \\
\hline \multicolumn{6}{|c|}{ Lynn } \\
\hline January & 339 & 323 & 306 & 323 & 10.4 \\
\hline February & 300 & 284 & 292 & 292 & 10.4 \\
\hline March & 333 & 310 & 300 & 314 & 10.1 \\
\hline April & 319 & 314 & 289 & 307 & 10.2 \\
\hline May & 348 & 335 & 309 & 331 & 10.7 \\
\hline June & 345 & 382 & 327 & 351 & 11.7 \\
\hline July & 382 & 362 & 344 & 363 & 11.7 \\
\hline August & 352 & 342 & 335 & 343 & 11.1 \\
\hline September & 348 & 308 & 318 & 325 & 10.8 \\
\hline October & 327 & 298 & 314 & 313 & 10.1 \\
\hline November & 306 & 276 & 292 & 292 & 9.7 \\
\hline December & 307 & 289 & 310 & 302 & 9.7 \\
\hline Total & 4,006 & 3,823 & 3,735 & 3,855 & 10.6 \\
\hline \multicolumn{6}{|c|}{ Peabody } \\
\hline January & 155 & 177 & 147 & 160 & 5.2 \\
\hline February & 140 & 150 & 143 & 144 & 5.2 \\
\hline March & 139 & 162 & 150 & 150 & 4.8 \\
\hline April & 140 & 162 & 149 & 150 & 5.0 \\
\hline May & 189 & 207 & 184 & 193 & 6.2 \\
\hline June & 180 & 289 & 203 & 224 & 7.5 \\
\hline July & 231 & 246 & 217 & 231 & 7.5 \\
\hline August & 208 & 225 & 201 & 211 & 6.8 \\
\hline September & 185 & 183 & 185 & 184 & 6.1 \\
\hline October & 153 & 177 & 172 & 167 & 5.4 \\
\hline November & 139 & 168 & 164 & 157 & 5.2 \\
\hline December & 152 & 183 & 180 & 172 & 5.5 \\
\hline Total & 2,011 & 2,329 & 2,095 & 2,145 & 5.9 \\
\hline \multicolumn{6}{|c|}{ Salem-Beverly } \\
\hline January & 302 & 287 & 303 & 297 & 9.6 \\
\hline February & 262 & 258 & 207 & 243 & 8.7 \\
\hline March & 283 & 282 & 299 & 288 & 9.3 \\
\hline April & 278 & 280 & 292 & 283 & 9.4 \\
\hline May & 319 & 322 & 309 & 316 & 10.2 \\
\hline June & 314 & 404 & 327 & 348 & 11.6 \\
\hline July & 384 & 384 & 352 & 373 & 12.0 \\
\hline August & 343 & 369 & 333 & 348 & 11.2 \\
\hline September & 319 & 320 & 323 & 321 & 10.7 \\
\hline October & 307 & 299 & 308 & 304 & 9.8 \\
\hline November & 279 & 278 & 288 & 282 & 9.4 \\
\hline December & 278 & 286 & 299 & 288 & 9.3 \\
\hline Total & 3,667 & 3,768 & 3,640 & 3,692 & 10.1 \\
\hline
\end{tabular}




\section{Permitted Water Withdrawals}

The amount of water that can be withdrawn from the Ipswich River by each of the three supply systems is regulated by the MDEP. In May 2003, the MDEP issued modified withdrawal permits to suppliers obtaining water from the Ipswich River Basin (Madelyn Morris, MDEP Deputy Region Director, Bureau of Resource Protection, written commun., May 19, 2003). These permits were established to balance public-watersupply needs and environmental interest. The effects of the permit conditions described below on the surface-water withdrawals were simulated to analyze the reservoir storage and firm yield of each system. The firm-yield analysis also included average 1989-95 ground-water withdrawals so that other demands that affect streamflow would be incorporated in the model.

The MDEP currently (2003) permits Lynn, Peabody, and Salem-Beverly to withdraw water from the Ipswich River between November 1 and May 31, when the river flow is above a minimum threshold of $1.0 \mathrm{ft}^{3} / \mathrm{s} / \mathrm{mi}^{2}$. Suppliers are also permitted to skim high flows between June 1 and October 31 . The flow thresholds are indexed to two USGS streamflowgaging stations on the Ipswich River (fig. 1), the South Middleton station (01101500) and the Ipswich station (01102000). Lynn and Peabody can withdraw water during the November through May period only when streamflow at the South Middleton station can be maintained above $44 \mathrm{ft}^{3} / \mathrm{s}$ $\left(1.0 \mathrm{ft}^{3} / \mathrm{s} / \mathrm{mi}^{2}\right)$. Salem-Beverly can withdraw water during the November through May period only when streamflow at the Ipswich station can be maintained above $125 \mathrm{ft}^{3} / \mathrm{s}$. Lynn and Peabody are permitted to withdraw water between June and October when flow is above $141 \mathrm{ft}^{3} / \mathrm{s}$ at the South Middleton station, and Salem-Beverly is permitted to withdraw water during this period when flow is above $381 \mathrm{ft}^{3} / \mathrm{s}$ at the Ipswich station. To maintain streamflow above these thresholds requires flow to be at or above the threshold plus the pumping rate. At a minimum, this value equals the streamflow requirement plus the lowest pumping rate.

The Lynn and Salem-Beverly intakes are upstream of the streamflow-gaging stations to which they are indexed; therefore, the flows at these stations include the effects of withdrawals. Peabody withdraws water downstream of the South Middleton station; therefore, its withdrawals must be subtracted from streamflow at the South Middleton station to determine whether the flow criteria are met.

Lynn's diversion of the Saugus River is not restricted, but the 2003 permits recommend that diversions be limited to flow thresholds determined from an Instream Flow Incremental Methodology (IFIM) study conducted by Gomez and Sullivan Engineers (2002). The recommended flow thresholds for the Saugus River were $0.29 \mathrm{ft} 3 / \mathrm{s} / \mathrm{mi}^{2}$ during June through
September, $0.57 \mathrm{ft} 3 / \mathrm{s} / \mathrm{mi}^{2}$ during October through February, $1.14 \mathrm{ft}^{3} / \mathrm{s} / \mathrm{mi}^{2}$ during March through April, and $0.95 \mathrm{ft}^{3} / \mathrm{s} / \mathrm{mi}^{2}$ during May. These flow thresholds were used to limit modelsimulated diversions from the Saugus River in this study.

In addition to the streamflow-triggered restrictions, MDEP limits the annual volume that can be withdrawn for each supply system. Annual withdrawal limits were registered under the Water Management Act Program (referred to as the registered volume) with a small additional amount authorized under the withdrawal permits. Lynn is registered to obtain an annual maximum volume of $956 \mathrm{Mgal}$ from the Ipswich River and 3,259 Mgal from the Saugus River. Lynn is also permitted to withdraw an additional $120 \mathrm{Mgal} / \mathrm{yr}$ from either the Ipswich or Saugus Rivers. This additional amount was applied to the Ipswich River withdrawals (total annual withdraw limit of $1,076 \mathrm{Mgal} / \mathrm{yr}$ ) because results of prior simulations (Zarriello, 2002) indicated that withdrawals from the Saugus River were limited by streamflow. Peabody can withdraw an annual volume of 1,632 Mgal/yr from the Ipswich River Basin (registered volume of $1,420 \mathrm{Mgal} / \mathrm{yr}$ plus a permitted volume of $212 \mathrm{Mgal} / \mathrm{yr}$ ), which includes two inactive ground-watersupply wells. The 2003 permit restricts direct withdrawals from the Ipswich River to $1,500 \mathrm{Mgal} / \mathrm{yr}$. Peabody is also registered to obtain an annual volume of $690 \mathrm{Mgal} / \mathrm{yr}$ from the North Coastal Basin by direct drainage to its reservoirs in that basin. This volume was not considered in the model simulations because water managers have no practical way of determining the direct-drainage contribution and the contributing drainage area in the North Coastal Basin (direct drainage including the reservoir surface area to Spring Pond, Long Basin, and Fountain Pond; fig. 1) is about 270 acres. Salem-Beverly can withdraw an annual volume of 4,128 Mgal (registered volume of $3,712 \mathrm{Mgal} / \mathrm{yr}$ plus a permitted volume of $416 \mathrm{Mgal} / \mathrm{yr}$ ). The MDEP permit restrictions are summarized in table 2 .

\section{Model Description}

The HSPF precipitation-runoff model (Bicknell and others, 1997) was developed and calibrated for the Ipswich River Basin by Zarriello and Ries (2000) to simulate the effects of water withdrawals on streamflow. The model was later modified to evaluate the firm yield and changes in storage of the Lynn, Peabody, and Salem-Beverly water-supply systems under the then current permit restrictions and hypothetical restrictions to protect fish habitat (Zarriello, 2002). The modified Ipswich River Basin HSPF model is well suited for the analysis of water-supply systems that obtain water from the basin because it can simulate hydrologic budgets of each system and water-withdrawal restrictions. 


\section{Simulated Effects of the 2003 Permitted Withdrawals and Water-Management Alternatives, Ipswich River Basin, MA}

Table 2. Massachusetts Department of Environmental Protection 2003 permitted surface-water withdrawals from the Ipswich River Basin, Massachusetts.

$\left[\mathrm{ft}^{3} / \mathrm{s}\right.$, cubic foot per second; $\mathrm{ft}^{3} / \mathrm{s} / \mathrm{mi}^{2}$, cubic foot per second per square mile; Mgal/d, million gallons per day]

\begin{tabular}{|c|c|c|c|c|c|c|}
\hline \multirow{2}{*}{ Supplier } & \multirow{2}{*}{$\begin{array}{l}\text { Permitted withdrawal } \\
\text { period }\end{array}$} & \multicolumn{4}{|c|}{ Streamflow threshold } & \multirow{2}{*}{$\begin{array}{c}\text { Annual volume } \\
\text { (Mgal) }\end{array}$} \\
\hline & & $\mathrm{ft}^{3} / \mathrm{s} / \mathrm{mi}^{2}$ & $\mathrm{ft}^{3} / \mathrm{s}$ & Mgal/d & Reference station & \\
\hline Lynn & November 1-May 31 & 1.0 & 44.5 & 28.8 & South Middleton & 1,076 \\
\hline \multirow[t]{2}{*}{ Peabody } & November 1-May 31 & 1.0 & 44.5 & 28.8 & South Middleton & 1,500 \\
\hline & June 1-October 31 & 3.17 & 141 & 91.1 & & \\
\hline
\end{tabular}

The HSPF model is constructed as a series of one-line records, referred to as the User Control Input (uci) file. These records are grouped by modules that represent hydrologic processes or control operational and data-management aspects of the model. HSPF consists of three main hydrologic processes modules-PERLNDs, which simulate pervious area runoff; IMPLNDs, which simulate runoff from impervious areas; and RCHRESs, which simulate flow in stream reaches and reservoirs. PERLNDs and IMPLNDs are characterized by Hydrological Response Units (HRUs), areas that produce a hydrologically similar response to meteorologic conditions. In the Ipswich River Basin HSPF model, 15 pervious-area HRUs and 2 impervious-area HRUs, characterized by similar land use or surficial material, or both, represent response units in the basin. Surface flow from IMPLNDs and surface and subsurface flow from PERLNDs were directed into 67 RCHRESs to represent the drainage network of the Ipswich River Basin. Flows from HRUs and RCHRESs were simulated with a 1-hour time step.

An external database, Water Data Management (WDM) system, stores all time-series data associated with the model. HSPF has several data-management modules to control input and output to the WDM database. Input data, such as precipitation, is read through the model's EXT SOURCE block. Output from the model is returned to the WDM database through the model's EXT TARGETS block. The WDM system is organized by data-set number (DSN) and attribute information. The WDM file can be accessed through a text-based interface program, ANNIE (Flynn and others, 1995), or graphical interface programs such as GenScn (Kittle and others, 1998) or WDMUtil (Hummel and others, 2001).

\section{Modifications to the HSPF Model}

Modifications to the HSPF model required to evaluate reservoir storage and firm yields were mostly made in the first firm-yield study (Zarriello, 2002). In this previous analysis of the water-supply systems, the general modeling approach was to combine the characteristics of multiple reservoirs into a single reservoir for each of the three water supplies. HSPF special actions were developed for each system to evaluate the reservoir-storage deficit, determine whether criteria for withdrawing water from its source or sources could be met; and when these criteria were met, withdraw water from the respective source(s) within the physical constraints of each system. Modifications to the model necessary for the present study were generally limited to changing the streamflow-threshold criteria for water-supply withdrawals.

The simplified representation of the reservoir systems and inclusion of portions of the system outside of the Ipswich River Basin required structural changes to the original Ipswich River Basin HSPF model. The collective stage, storage, surface-area characteristics (FTABLE) of individual reservoirs in each system were defined by a single RCHRES. The maximum storage of the combined reservoir was defined as the sum of the maximum storage of the individual reservoirs. Reservoir storage was assumed to decline linearly over the range in stage from the reported maximum and minimum capacity of individual reservoirs, except for Salem-Beverly Wenham Lake and Putnamville Reservoirs, where detailed information about stage, storage, and surface area was available. The storage of individual reservoirs at each stage was summed to obtain the combined-reservoir storage simulated in the HSPF model.

Withdrawals from each reservoir were averaged from the monthly 1998-2000 demands reported to MDEP as previously described (table 1). Demands for the Lynn and Peabody systems included water purchased from outside the basin. This demand reflects the seasonal pattern of water use and was the basis for calculating the firm yield of each system (calculated as a percentage of current demands). The average monthly demands were disaggregated into mean daily values and read into the model through the EXT SOURCE block from DSNs 191, 192, and 193 for the Lynn, Peabody, and Salem-Beverly systems, respectively. All other withdrawals, which were primarily based on 1989-93 withdrawals, remained the same as previously simulated. 
The combined storage of Lynn's reservoirs (3,937 Mgal) was incorporated into the model as RCHRES 91, but was assigned the same location attribute as the Saugus River (RCHRES 90). Direct drainage to Lynn's reservoirs (2,702 acres) was added to RCHRES 91 as PERLND 8 (the PERLND that best represents the type of land cover and surficial material). The Saugus River Basin was added to the Ipswich River Basin HSPF model by Zarriello (2002) as RCHRES 90 (fig. 1). The drainage area above Lynn's water-supply diversion on the Saugus River $\left(10.63 \mathrm{mi}^{2}\right)$ is nearly the same area and of similar surficial geology to the combined drainage area of RCHRESs 3, 9, and $11\left(10.84 \mathrm{mi}^{2}\right)$ in the Ipswich River Basin. Thus, flow values in these reaches were combined through the HSPF COPY function and written to RCHRES 90 to obtain flow in the Saugus River at the point of the Lynn water-supply diversion. Lynn's withdrawals from the Ipswich River were taken from RCHRES 18 (fig. 1) through the second exit gate. A RCHRES can have up to five exit gates. Typically, the first exit gate is used for withdrawals, if they are present, and the second exit gate is used for routing flow to downstream reaches. The first exit gate in RCHRES 18 was used to specify a minor irrigation withdrawal.

The combined storage of the Peabody reservoirs (1,250 Mgal) was incorporated in RCHRES 21 , which formerly represented Suntaug Lake (fig. 1). Direct drainage to RCHRES 21 (596 acres) was increased by 270 acres (added to PERLND 8) to account for the drainage area to the Spring Pond reservoir system. Except for this direct drainage contribution to its reservoirs, Peabody obtains water from the Ipswich River at RCHRES 20 through the first reach exit gate.

The combined storage of the Salem-Beverly reservoirs (3,555 Mgal) was incorporated into RCHRES 45, which formerly represented Putnamville Reservoir (fig. 1). The drainage areas to Longham Reservoir and Wenham Lake (RCHRES 61 and 62, respectively) were added to the drainage areas of respective HRUs in RCHRES 45 (total drainage area 4,257 acres). Diversions from the Ipswich River caused by withdrawals made from the Salem-Beverly Canal (RCHRES 44) were simulated as withdrawals from the first exit gate of RCHRES 43 (fig. 1).

\section{Special Actions}

The special-actions feature of the HSPF model provides programmed instructions within the uci file to control the time and rate at which water was obtained from its source(s) according to the withdrawal restrictions, reservoir storage, and limitations of the system infrastructure. Special actions were largely developed during the first firm-yield study (Zarriello, 2002), and only minor modifications were required to simulate withdrawal restrictions for this study. The special actions associated with the reservoir simulations described below are presented in the appendix.

\section{Lynn System}

Lynn's water-supply demands were first satisfied by withdrawals from the Saugus River (RCHRES 90). Demands that could not be met from the Saugus River were made through withdrawals from the Ipswich River (RCHRES 18) according to the following rules:

1. Withdrawals were stopped when the maximum storage capacity of the reservoir (3,937 Mgal) was satisfied.

2. Withdrawals from the Ipswich River were stopped when the authorized annual volume (1,076 Mgal/yr) was reached. Withdrawals from the Saugus River were stopped when the authorized annual volume (3,259 Mgal/yr) was reached.

3. Diversions from the Saugus River (gravity-fed) were limited by pipe size and the head (water-level) difference between the Saugus River and Hawkes Pond. The head difference, for the purposes of this analysis, was considered to depend on the reservoir stage, which is a function of reservoir storage. The upper diversion limit, $26 \mathrm{ft}^{3} / \mathrm{s}$ (17 Mgal/d), was reached when the reservoir storage was low (below 80 percent of capacity). The lower diversion limit, $15 \mathrm{ft}^{3} / \mathrm{s}$ (10 Mgal/d), was reached when the reservoir storage was high (above 95 percent of capacity). Diversions were scaled linearly between these limits.

Diversions from the Saugus River were restricted to the IFIM recommended streamflow requirements. Diversions were stopped when streamflows at RCHRES 90 were below $3.1 \mathrm{ft}^{3} / \mathrm{s}$ from June through September, 6.1 $\mathrm{ft}^{3} / \mathrm{s}$ from October through February, $12 \mathrm{ft}^{3} / \mathrm{s}$ in March and April, and $10 \mathrm{ft}^{3} / \mathrm{s}$ in May.

4. Withdrawals from the Ipswich River were limited to the two present pumping rates- 14 and $18 \mathrm{Mgal} / \mathrm{d}$ (22 and $28 \mathrm{ft}^{3} / \mathrm{s}$, respectively), except for the simulation with a hypothetical 5 -Mgal/d $\left(7.7 \mathrm{ft}^{3} / \mathrm{s}\right)$ capacity pump. The model simulated the maximum pumping rate needed to satisfy the reservoir-storage deficit and maintain streamflow above the seasonal threshold criteria.

5. Withdrawals from the Ipswich River were permitted between November 1 and May 31 when streamflow of at least $1.0 \mathrm{ft}^{3} / \mathrm{s} / \mathrm{mi}^{2}\left(44.5 \mathrm{ft}^{3} / \mathrm{s}\right)$ could be maintained at the South Middleton station (RCHRES 19). Withdrawals were permitted between June 1 and October 31 when streamflow at the South Middleton station could be maintained above $141 \mathrm{ft}^{3} / \mathrm{s}$. Withdrawals from the Ipswich River were stopped when these conditions were not satisfied. 


\section{Simulated Effects of the 2003 Permitted Withdrawals and Water-Management Alternatives, Ipswich River Basin, MA}

Withdrawals for the Lynn water-supply system from the Saugus and Ipswich Rivers controlled by the special actions described above are illustrated for 1989 in figures $2 A$ and $2 B$, respectively. In this example, the supply reservoir was assumed to start at full capacity to illustrate that diversions were stopped when the reservoir reached full capacity. Diversions from the Saugus River were made during most times of the year except when streamflow was below the minimum recommended seasonal flow or when the reservoir was at full capacity. Withdrawals from the Ipswich River are illustrated for the present 14- and 18-Mgal/d pump rates. Withdrawals from the Ipswich
River were often not made even when streamflow was above the permitted threshold because the reservoir was at capacity or the amount of water needed to satisfy the storage deficit was obtained from Saugus River diversions (fig. 2B). During periods when the reservoir was near capacity and diversions from the Saugus River could not satisfy the storage deficit, withdrawals from the Ipswich River resulted in frequent onand-off cycles (for example, withdrawals shown during April and May). Frequent on-and-off cycles also resulted when streamflow, plus the pumping rate, was near the permitted flow threshold.

A. SAUGUS RIVER

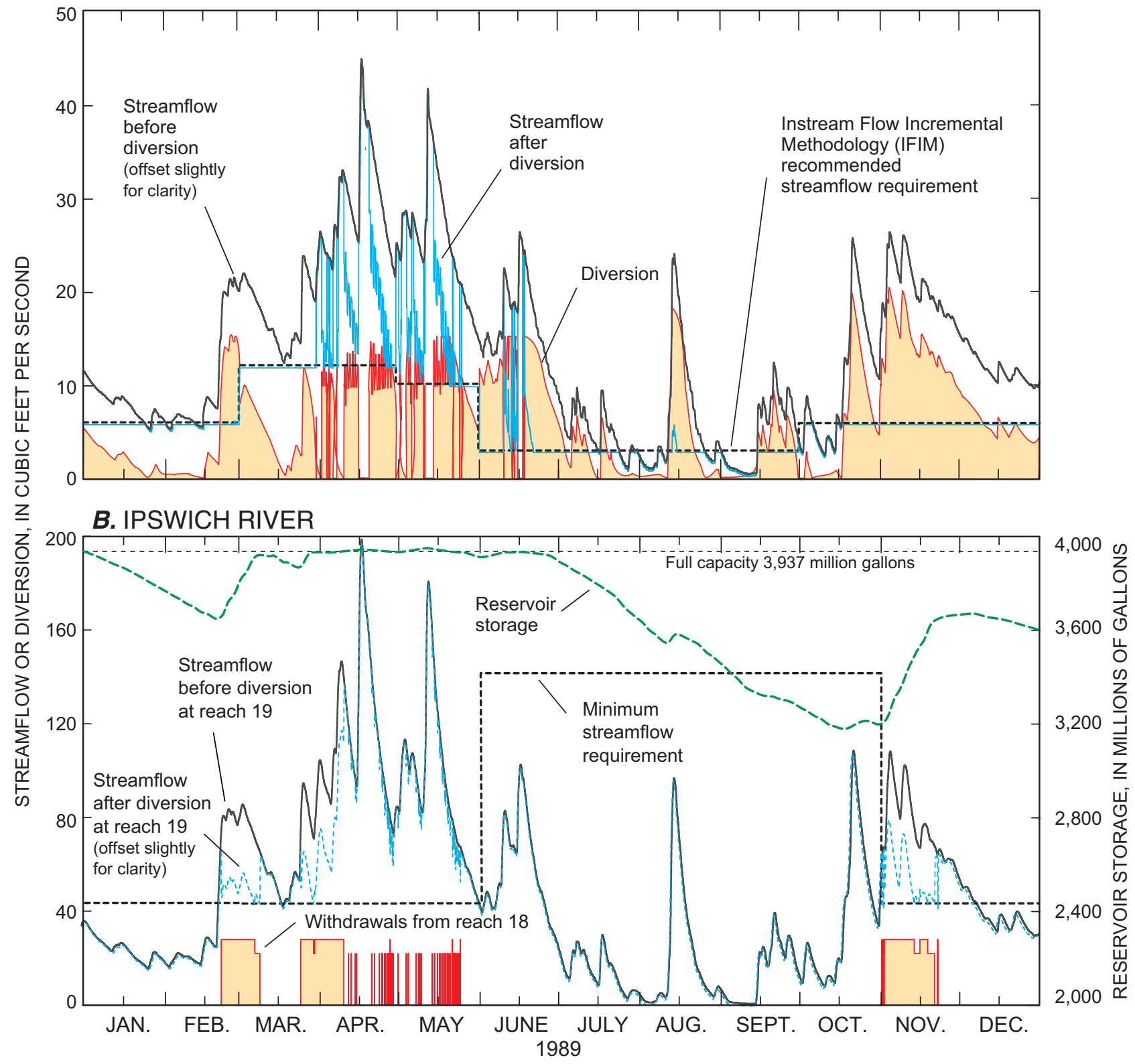

Figure 2. Example of withdrawals limited by the Hydrologic Simulation Program-FORTRAN (HSPF) special actions from the $A$, Saugus River under the Instream Flow Incremental Methodology (IFIM) recommended flows and the $B$, Ipswich River under the 2003 permitted withdrawals, Lynn water-supply system, Massachusetts, 1989 [reach locations shown in fig. 1]. 


\section{Peabody System}

Peabody water-supply demands were satisfied from withdrawals from the Ipswich River (RCHRES 20) according to the following rules:

1. Withdrawals were stopped when the maximum storage capacity of the reservoir $(1,250 \mathrm{Mgal})$ was satisfied.

2. Withdrawals were stopped when the authorized annual volume (1,500 Mgal/yr) from the Ipswich River was reached.

3. Withdrawals were limited to the three present pumping rates-4, 11, and $18 \mathrm{Mgal} / \mathrm{d}\left(6.2,17\right.$, and $28 \mathrm{ft}^{3} / \mathrm{s}$, respectively), except for the simulation with a hypothetical 2-Mgal/d (3.1 ft $3 / \mathrm{s})$ capacity pump. The model simulated the maximum pumping rate needed to satisfy the reservoir-storage deficit and maintain streamflow above the seasonal threshold criteria.

4. Withdrawals from the Ipswich River were permitted between November 1 and May 31 when streamflow at the South Middleton station (RCHRES 19), plus the pumping rate, was greater than $1.0 \mathrm{ft}^{3} / \mathrm{s} / \mathrm{mi}^{2}\left(44.5 \mathrm{ft}^{3} / \mathrm{s}\right)$. Withdrawals were permitted between June 1 and October 31 when streamflow at RCHRES 19 was above $141 \mathrm{ft}^{3} / \mathrm{s}$ plus the pumping rate. Withdrawals from the Ipswich River were stopped when these conditions were not satisfied.
Withdrawals for the Peabody water-supply system from the Ipswich River controlled by the special actions described above are illustrated for 1989 in figure 3. In this example, the supply reservoir was assumed to start at full capacity. Withdrawals are shown for the present 4-, 11-, and 18-Mgal/d pumps and for the hypothetical 2-Mgal/d pump. Under the permit restrictions, withdrawals from the Ipswich River were made between November 1 and May 31 when streamflow, plus the pumping rate, was equal to or greater than $44.5 \mathrm{ft}^{3} / \mathrm{s}$ at the South Middleton station. Conditions suitable for withdrawals between June 1 and October 31, when streamflow, plus the pumping rate, was equal to or greater than $141 \mathrm{ft}^{3} / \mathrm{s}$ at the South Middleton station, were not met during 1989. The pumping rate was added to the streamflow threshold at South Middleton station to maintain the $1.0 \mathrm{ft}^{3} / \mathrm{s} / \mathrm{mi}^{2}$ flow criterion at the supply intake. Streamflow in reach 20, after the water-supply diversion, is shown to illustrate that target streamflows were maintained even though the reference streamflow-gaging station is upstream of the intake. This example also illustrates that withdrawals are mostly made at the lower pump rate because streamflow was too low to meet the withdrawal criterion or the reservoir was near capacity when streamflow was sufficient to sustain the higher pump rates.

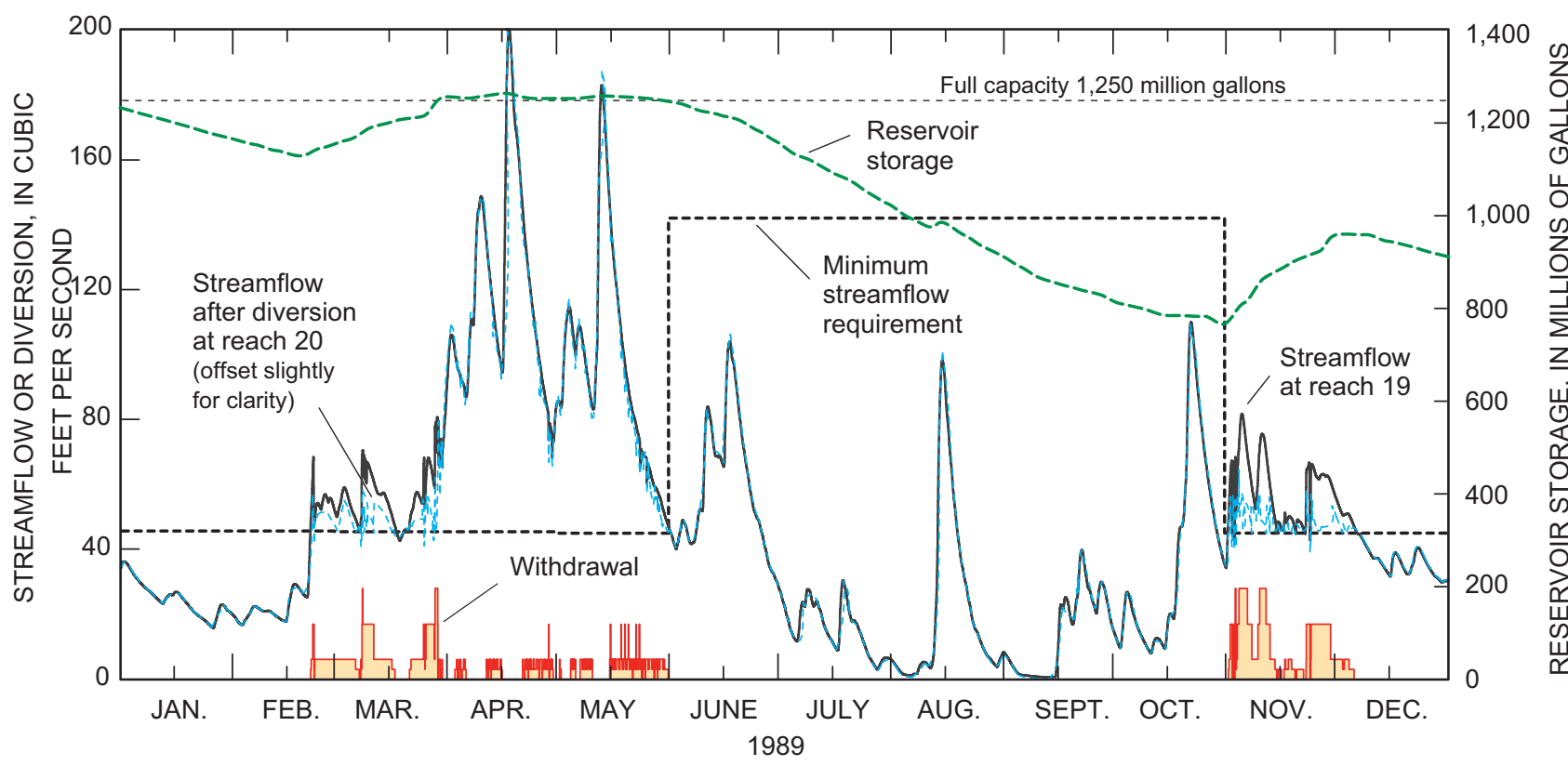

Figure 3. Example of withdrawals limited by the Hydrologic Simulation Program-FORTRAN (HSPF) special actions under 2003 permitted withdrawals from the Ipswich River, Peabody water-supply system, Massachusetts, 1989 [example includes a hypothetical low-capacity pump—2 million gallons per day (Mgal/d); reach locations shown in fig. 1]. 


\section{Salem-Beverly System}

Salem-Beverly water-supply demands were satisfied from withdrawals from the Ipswich River (RCHRES 43) according to the following rules:

1. Withdrawals were stopped when the maximum storage capacity of the reservoir (3,555 Mgal) was satisfied.

2. Withdrawals were stopped when the authorized annual volume (4,128 Mgal/yr) from the Ipswich River was reached.

3. Withdrawals were limited to the two present pumping rates-25 and $50 \mathrm{Mgal} / \mathrm{d}$ (39 and $77 \mathrm{ft}^{3} / \mathrm{s}$, respectively), except for the simulation with a hypothetical $10-\mathrm{Mgal} / \mathrm{d}$ $\left(15 \mathrm{ft}^{3} / \mathrm{s}\right)$ capacity pump. The model simulated the maximum pumping rate needed to satisfy the reservoirstorage deficit and maintain streamflow above the seasonal threshold criteria.

4. Withdrawals from the Ipswich River were permitted between November 1 and May 31 when streamflow at the Ipswich station (RCHRES 56) could be maintained at $1.0 \mathrm{ft}^{3} / \mathrm{s} / \mathrm{mi}^{2}\left(125 \mathrm{ft}^{3} / \mathrm{s}\right)$ or greater. Withdrawals were also permitted between June 1 and October 31 when streamflow at the Ipswich station could be maintained at $381 \mathrm{ft}^{3} / \mathrm{s}$ or greater. Withdrawals from the Ipswich River were stopped when these conditions were not satisfied.
Withdrawals for the Salem-Beverly water-supply system from the Ipswich River controlled by the special actions described above are illustrated for the 1989 calendar year in figure 4. Unlike the previous two examples (Lynn and Peabody), the Salem-Beverly reservoir storage was started at a level previously simulated from long-term records. Withdrawals are shown for the two present $25 \mathrm{Mgal} / \mathrm{d}$ pumps and for the hypothetical $10 \mathrm{Mgal} / \mathrm{d}$ pump. The simulated pumping rate depended on streamflow and the reservoir-storage deficit. The storage deficit from the previous year (1988) recovered in late March through early May of 1989 when withdrawals could be sustained at the $50 \mathrm{Mgal} / \mathrm{d}$ rate. During the peak flow of the year (in mid-May), no withdrawals were made from the Ipswich River because the water-supply demands could be met from the direct drainage to the reservoirs.

\section{Limitations}

The limitations and uncertainties of the Ipswich River Basin HSPF model are described by Zarriello and Ries (2000). In addition to the limitations of the underlying HSPF model, primarily having to do with the uncertainty associated with data used in the simulation or model calibration, and the possibility of alternative model structures and variable values that can produce equally acceptable results, several other factors should be considered when the results of this study are evaluated. Aggregation of multiple reservoirs in each system was necessary to avoid simulating reservoir management.

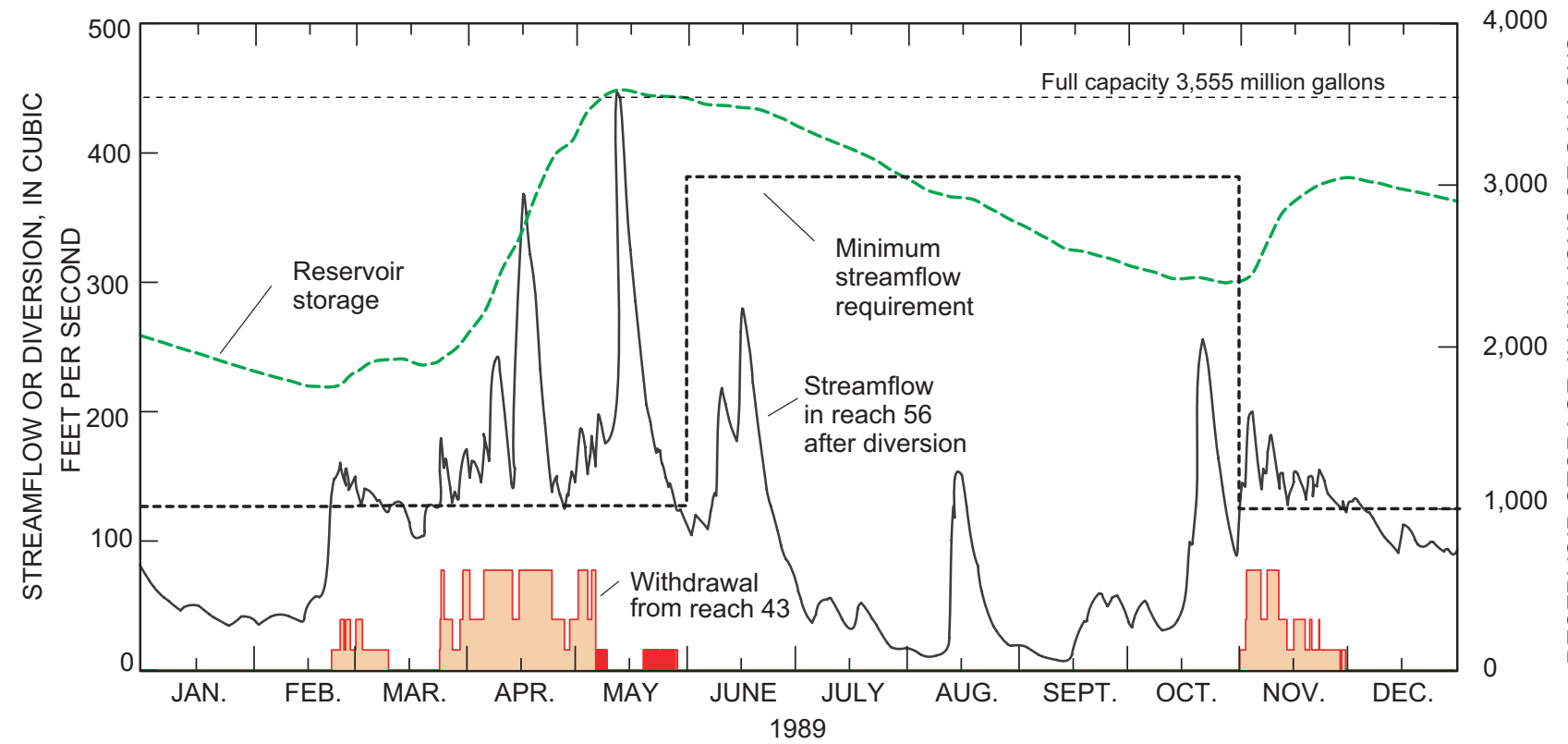

Figure 4. Example of withdrawals limited by the Hydrologic Simulation Program-FORTRAN (HSPF) special actions from the Ipswich River under the 2003 permitted withdrawals, Salem-Beverly water-supply system, Massachusetts, 1989 [example includes a hypothetical low-capacity pump-10 million gallons per day (Mgal/d); reach locations shown in fig. 1]. 
The dynamics of reservoir management are not readily defined; and even if they could be defined, complex special actions would be required to simulate these operations in the model. Management operations could affect storage; for example, a supplier might not withdraw water when conditions allow because of water-quality considerations. If streamflow conditions later fail to satisfy the permitted withdrawal criteria, the actual storage would likely be less than simulated. This difference could affect the yield of a system because the systems storage deficit is satisfied in the model simulations whenever possible.

Withdrawals are simulated to the maximum extent possible within the constraints allowed, that is, withdrawals can cycle on and off or switch between pumping rates in a relatively short time (as indicated by the "painting" of the withdrawals in figs. 2-4). Water suppliers are unlikely to operate their system in this fashion for economic reasons; and thus, the amount of water supplied to the reservoir under these conditions is oversimulated. Furthermore, water suppliers may not be able to lower reservoirs to the minimum reported level because of engineering or water-quality constraints. For example, when reservoir stage approaches the invert elevation of the intake, pumps could cavitate, effectively lowering the usable reservoir storage.

This study provides a deterministic (failure free) yield of the reservoir system under permitted or alternative withdrawal constraints for the historical period 1961-95. A failure-free yield is not plausible in a probabilistic context if the withdrawals are greater than the lower boundary of the inflow distribution (Koutsoyiannis, 2004). That is, reservoirs could fail and not meet demands if withdrawals exceed the lowest possible inflows to the system. The lower boundary of the inflow distribution is unknown because the simulation period does not encompass long-term climate variability or possible climate change. Probabilistic failures could be computed by Monte Carlo simulations of synthesized input time series (precipitation and potential evapotranspiration) within the probable space of values (Bayesian methods) or simulation of synthesized-input time series that span hundreds or thousands of years (bootstrapping methods). The computation of probabilistic failures was beyond the scope of this study, however.

\section{Effects of 2003 Permitted}

\section{Withdrawals and Water-Management Alternatives on Reservoir Storage and Firm Yield}

The effects of the 2003 permit restrictions on the Lynn, Peabody, and Salem-Beverly reservoir storage were evaluated by means of HSPF simulations. Simulations were made with average 1998-2000 demands or a fraction of these demands to determine firm yield of each system for the 1961-95 period. In addition to the simulation of the current permitted withdrawals, four water-management alternatives were evaluated as part of this study. These included simulations of the 2003 permitted withdrawals with the addition of a hypothetical low-capacity pump for each system, seasonally modifying the streamflow threshold withdrawal criteria, and evaluating the yield of each system at successive failures. All simulations made during this study were assigned a $u c i$-file prefix name and an IDSCEN value (attribute associated with the WDM file that identifies the scenario) of "FY-IPRx," where the number $x$ identifies the scenarios simulated during this study (table 3 ).

The WDM file developed for the Ipswich River Basin HSPF model (Ips.wdm) was replaced with a new WDM file (Ips2.wdm) to minimize its size. The new WDM file contains all the input time-series data to run the model and the output time series simulated during this study. Output data sets are organized by a 4-digit DSN summarized in table 4. In general, the first digit (thousands) identifies the withdrawal rate simulated, the second digit (hundredths) identifies the scenario, the third digit (tenths) identifies the type of information, and the fourth digit identifies the location. The exceptions to this numbering scheme are DSNs of simulated discharge at streamflow-gaging stations; these DSNs end with the modelreach number corresponding to the station location (either 19 or 56).

Simulations were made at an hourly time step; however, storage and flow characteristics are reported as daily, monthly, or yearly averages. Precipitation gains and evaporation losses at the reservoir surface are considered in the HSPF model, but not discussed in this report. Previous simulation results (Zarriello, 2002) indicated that inflows from direct precipitation and outflows to evaporation were not large components of the hydrologic budget of the reservoir systems.

Table 3. Description of Hydrologic Simulation ProgramFORTRAN (HSPF) simulations of reservoir storage and yields for the Lynn, Peabody, and Salem-Beverly water-supply systems, Massachusetts.

[IDSCEN, scenario-identification attribute in the Watershed Data Management (WDM) database; $u c i$, user control input for HSPF]

\begin{tabular}{|c|c|}
\hline $\begin{array}{l}\text { ucifile } \\
\text { prefix and } \\
\text { IDSCEN }\end{array}$ & Description \\
\hline FY-IPR1 & Firm yield under 2003 permitted withdrawals. \\
\hline FY-IPR2 & $\begin{array}{l}\text { Same as FY-IPR1 with hypothetical low-capacity } \\
\text { pumps. }\end{array}$ \\
\hline FY-IPR3 & $\begin{array}{l}\text { Firm yields under alternative seasonal streamflow } \\
\text { thresholds. }\end{array}$ \\
\hline FY-IPR4 & Yields at successive near failures of the reservoir. \\
\hline
\end{tabular}


Table 4. Identification attributes and organization of output time series simulated by the Hydrologic Simulation Program-FORTRAN (HSPF) for the analysis of reservoir storage and yields of the Lynn, Peabody, and Salem-Beverly water-supply systems, Massachusetts.

[IDCONS, constituent-identification attribute; IDLOCN, reach-location identification attribute; $\mathrm{ft}$, foot; $\mathrm{ft}^{3} / \mathrm{s}$, cubic foot per second; Mgal, million gallons; --,not applicable]

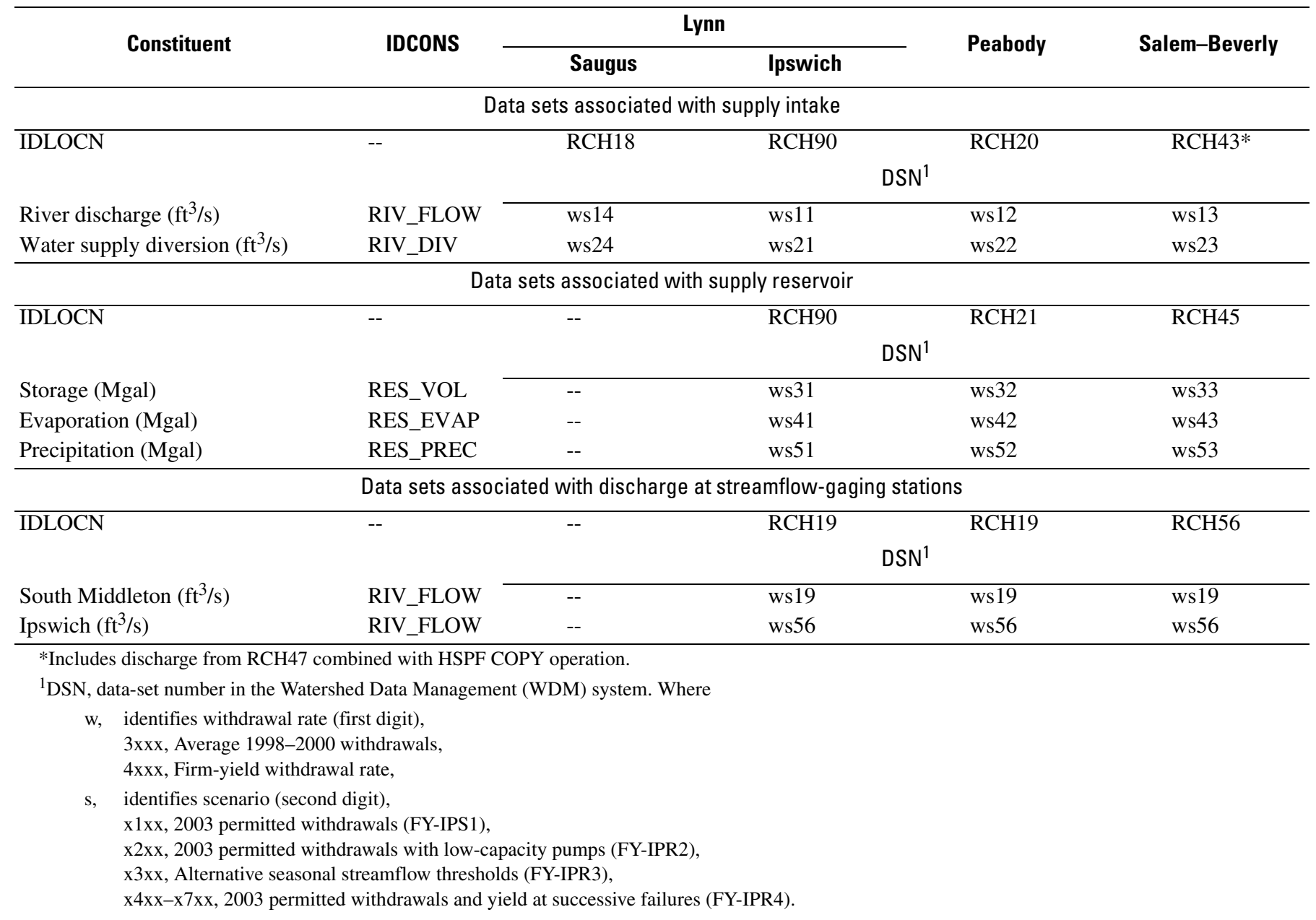

The firm yield of each supply system was calculated by incrementally decreasing average 1998-2000 demands (as all systems failed at these withdrawal rates) until the reservoir storage was nearly depleted. MFACT, a multiplier in the EXT SOURCE block of the uci file, was used to adjust withdrawal data read into the model. The firm yield reported was the withdrawal rate (made at two-significant digits to the right of the decimal) that maintained the least storage in the reservoir, but still satisfied demands. Yields are reported as an annual average rate in millions of gallons per day; actual withdrawal could be more or less on any given day.

The firm yield and changes in reservoir storage of each system is affected by upstream withdrawals. All withdrawals, except for withdrawals by Lynn, Peabody, and Salem-Beverly, were simulated at the average 1989-93 demands, which were included in the original Ipswich River Basin HSPF model. The withdrawals for the Lynn, Peabody, and Salem-Beverly water supplies were simulated at the rate appropriate to the simulation. For example, the Peabody-system firm yield was deter- mined by setting the Lynn withdrawal to its firm-yield rate and the Salem-Beverly-system firm yield was determined by setting the Lynn and Peabody withdrawals to their respective firm-yield rates.

\section{Permitted Withdrawals (FY-IPR1) and Permitted Withdrawals with a Low-Capacity Pump (FY-IPR2)}

The 2003 permitted withdrawals were simulated for each system to evaluate firm yields and reservoir storage under the average 1998-2000 demands. These simulations are identified by the uci file name and IDSCEN attribute of FY-IPR1.

These simulations were repeated with the addition of a hypothetical low-capacity pump in each system. Low-capacity pumps, relative to the present pumps, could provide additional water to the supply reservoirs because less water is needed above the permitted streamflow threshold to meet withdrawal 
criteria. Hypothetical pumps were simulated with capacities of $5 \mathrm{Mgal} / \mathrm{d}$ for Lynn, $2 \mathrm{Mgal} / \mathrm{d}$ for Peabody, and $10 \mathrm{Mgal} / \mathrm{d}$ for Salem-Beverly. These pumping rates are about 36,50 , and 40 percent of the lowest present pump rates for the Lynn, Peabody, and Salem-Beverly systems, respectively. These simulations are identified by the uci file name and IDSCEN attribute of FY-IPR2. Results of these simulations were generally similar to the results of scenario FY-IPR1; therefore, the two sets of results are presented concurrently.

\section{Lynn System}

Simulation results under the 2003 permitted withdrawals and average 1998-2000 demands (10.6 Mgal/d) indicate that reservoir storage was depleted in 4 of 35 years (fig. 5A). The minimum annual storage averaged 47 percent of capacity and was less than 50 percent of capacity in 14 years. Reservoir storage recovered to capacity or near capacity in most years (maximum annual storage averaged 93 percent of capacity). Following the periods of the most sever drought (1966 and 1981) the storage recovered to only about 25 percent of capacity. Also following these droughts storage did not fully recover during its normal recovery cycle for 1 or 2 years. The daily mean reservoir-storage-duration curve (fig. $5 B$ ) indicates that storage was depleted about 3 percent of the time and was less than 25 percent of capacity about 8 percent of the time. Simulation results with a hypothetical low-capacity pump are nearly identical to the simulation results without the lowcapacity pump.

\section{A. HYDROGRAPHS}

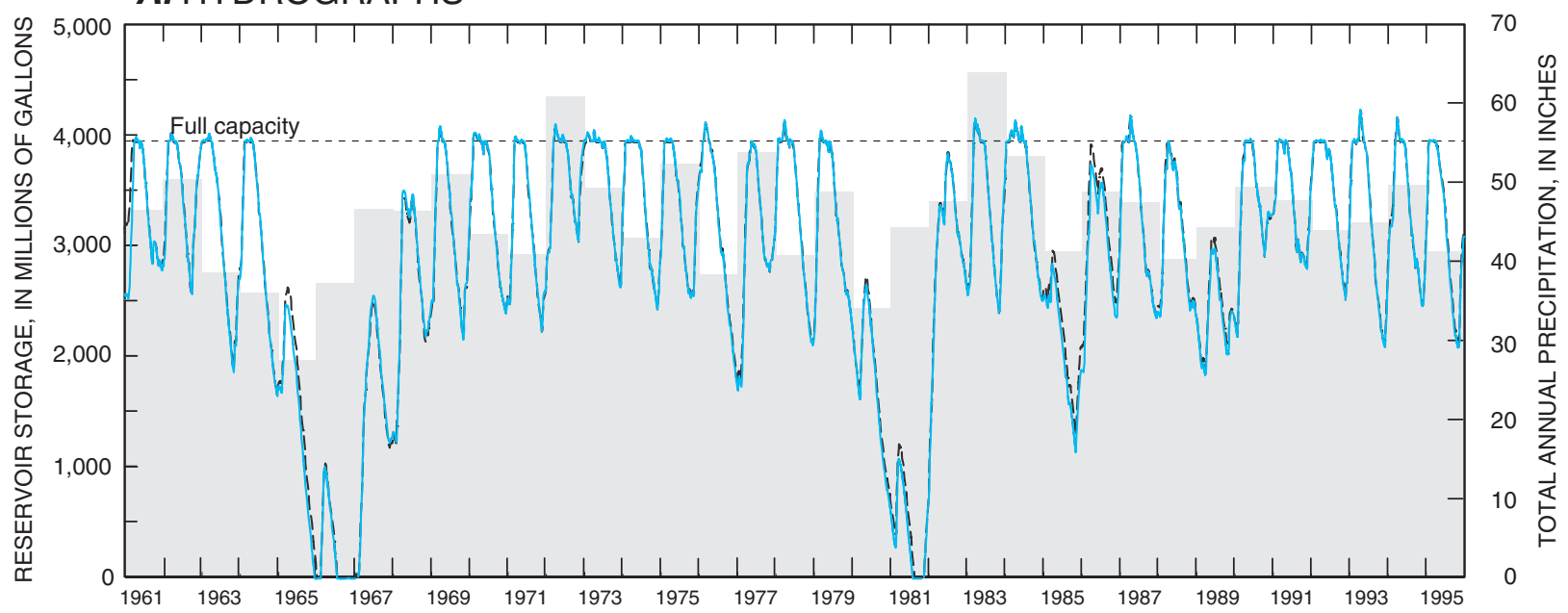

\section{B. DURATION CURVES}

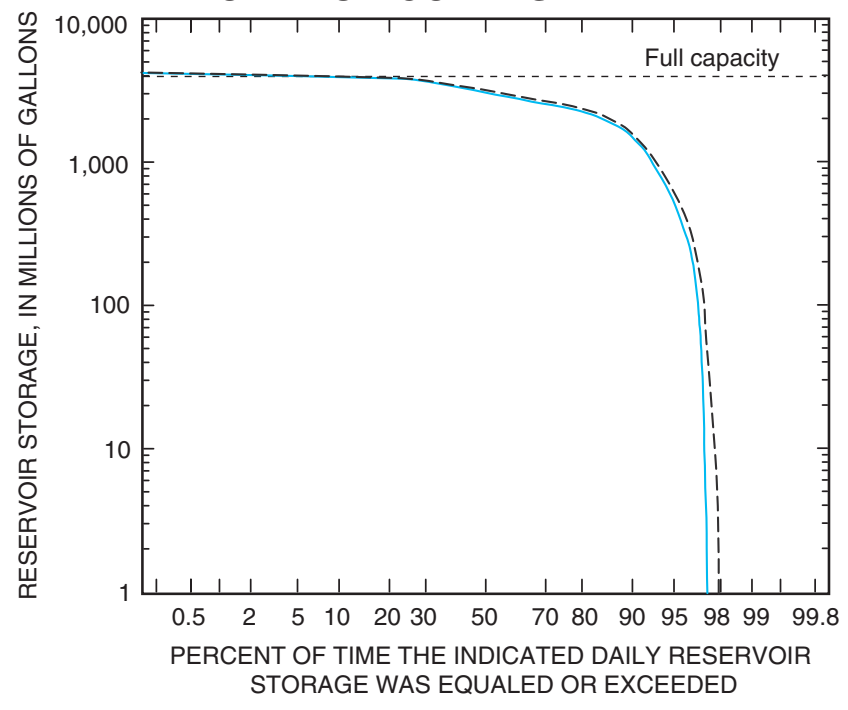

\section{EXPLANATION}

\section{TOTAL ANNUAL PRECIPITATION}

AVERAGE WITHDRAWAL RATE 10.6 MILLION GALLONS PER DAY

2003 permitted withdrawals

2003 permitted withdrawals with a hypothetical low-pump capacity

Figure 5. Daily mean reservoir storage $A$, hydrographs and $B$, duration curves simulated under average 1998-2000 demands and 2003 permitted withdrawals from the Ipswich River and Instream Flow Incremental Methodology (IFIM) recommended flow for the Saugus River, Lynn water-supply system, Massachusetts, 1961-95. 
Annual reservoir storage under the permitted withdrawals averaged 2,882 Mgal or about 73 percent of capacity. The average monthly reservoir storage (fig. 6 and table 5) was lowest between October and December (averaged between 57 and 60 percent of capacity, respectively) and highest in April and May (averaged about 89 and 88 percent of capacity, respectively). The average monthly storage was sustained at a slightly higher level with the simulation of the low-capacity pump; the additional gain in monthly average storage ranged from $25 \mathrm{Mgal}$ in September to $55 \mathrm{Mgal}$ in February. This gain represents less than 1 percent of the reservoir capacity.

Under the simulated conditions, 1998-2000 demands and the IFIM recommend flow, Lynn obtained water from the Saugus River nearly 60 percent of the time (fig. 7). Water was diverted from the Saugus River at the maximum gravity-feed rate $\left(26 \mathrm{ft}^{3} / \mathrm{s}\right)$ about 4 percent of the time. The annual diversion from the Saugus River averaged $6.63 \mathrm{ft}^{3} / \mathrm{s}(4.29 \mathrm{Mgal} / \mathrm{d})$ and ranged from 3.0 to $11.2 \mathrm{ft}^{3} / \mathrm{s}$ (1.94 to $7.24 \mathrm{Mgal} / \mathrm{d}$, respectively). The average annual diversion from the Saugus River is about 48 percent of the permitted annual withdrawal volume $(3,259$ Mgal). The maximum annual diversion $7.24 \mathrm{ft}^{3} / \mathrm{s}(1,709$ $\mathrm{Mgal} / \mathrm{yr}$ ) indicates that withdrawals from the Saugus River are not limited by the annual volume restriction. Diversions from the Saugus River were nearly unchanged by simulation of a hypothetical low-capacity pump on the Ipswich River.
Under the simulated conditions, 1998-2000 demands and 2003 permit restrictions, Lynn withdrew water from the Ipswich River about 14 percent of the time (fig. 7). Withdrawals from the Ipswich River were made mostly at the maximum pumping rate of $18 \mathrm{Mgal} / \mathrm{d}\left(28 \mathrm{ft}^{3} / \mathrm{s}\right)$; withdrawals at the 14 $\mathrm{Mgal} / \mathrm{d}\left(22 \mathrm{ft}^{3} / \mathrm{s}\right)$ pumping rate were infrequent. The annual diversion from the Ipswich River was $3.66 \mathrm{ft}^{3} / \mathrm{s}(2.37 \mathrm{Mgal} / \mathrm{d}$ or $864 \mathrm{Mgal} / \mathrm{yr}$ ); in 1965-66, 1980-81, and 1985 (drought years), annual diversion averaged $3.11 \mathrm{ft}^{3} / \mathrm{s}(2.01 \mathrm{Mgal} / \mathrm{d})$. In 14 years, withdrawals from the Ipswich River were limited by the annual permitted volume (1,076 Mgal/yr). This limitation was also indicated by the fact that the average monthly reservoir storage was lowest in November and December, even though the streamflow-withdrawal criterion was lowered at the beginning of November. The average annual volume obtained from the Ipswich River was about half that obtained from the Saugus River. The simulation with the low-capacity pump indicated that withdrawals from the Ipswich River increased slightly (fig. 7), but the annual volume withdrawn was unchanged during 14 years that were limited by the annual volume restriction. During the years when withdrawals were not limited by the annual volume restriction, the low-capacity pump increased the volume withdrawn from the Ipswich River by an average of 11 percent.

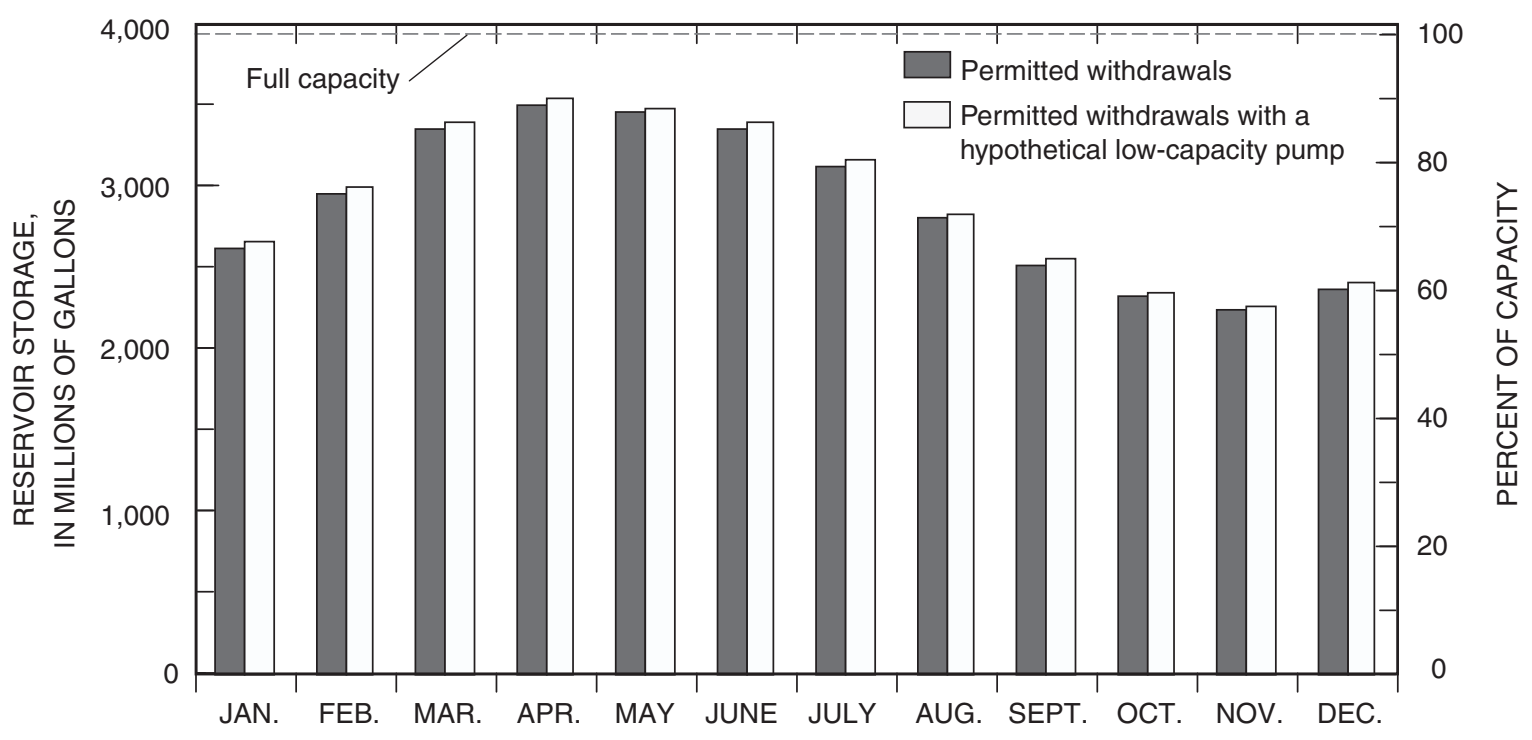

Figure 6. Average monthly reservoir storage simulated under average 1998-2000 demands (10.6 million gallons per day) and 2003 permitted withdrawals from the Ipswich River and Instream Flow Incremental Methodology (IFIM) recommended flow for the Saugus River, Lynn water-supply system, Massachusetts, 1961-95. 
Table 5. Average monthly reservoir storage and number of days during which the mean daily reservoir storage was depleted under average 1998-2000 demands (10.6 million gallons per day) and 2003 permitted withdrawals and under 2003 permitted withdrawals with a hypothetical low-capacity pump, Lynn water-supply system, Massachusetts, 1961-95.

[Instream Flow Incremental Methodology (IFIM) recommended streamflow thresholds applied to the Saugus River withdrawals. Total number of days storage depleted: Includes any day the minimum reservoir storage was zero. Mgal, million gallons]

\begin{tabular}{|c|c|c|c|c|c|c|c|c|}
\hline \multirow[b]{2}{*}{ Month } & \multicolumn{4}{|c|}{ Reservoir storage under permitted withdrawals } & \multicolumn{4}{|c|}{$\begin{array}{l}\text { Reservoir storage under permitted withdrawals } \\
\text { with low-capacity pump }\end{array}$} \\
\hline & $\begin{array}{c}\text { Average } \\
\text { monthly } \\
\text { (Mgal) }\end{array}$ & $\begin{array}{l}\text { Percent of } \\
\text { capacity }\end{array}$ & $\begin{array}{c}\text { Total number } \\
\text { of days } \\
\text { storage } \\
\text { depleted }\end{array}$ & $\begin{array}{l}\text { Percent of } \\
\text { time dry }\end{array}$ & $\begin{array}{c}\text { Average } \\
\text { monthly } \\
\text { (Mgal) }\end{array}$ & $\begin{array}{l}\text { Percent of } \\
\text { capacity }\end{array}$ & $\begin{array}{c}\text { Total number } \\
\text { of days } \\
\text { storage } \\
\text { depleted }\end{array}$ & $\begin{array}{l}\text { Percent of } \\
\text { time dry }\end{array}$ \\
\hline January & 2,614 & 66 & 47 & 4.3 & 2,668 & 68 & 20 & 1.8 \\
\hline March & 3,341 & 85 & 0 & 0 & 3,385 & 86 & 0 & 0 \\
\hline April & 3,503 & 89 & 0 & 0 & 3,530 & 90 & 0 & 0 \\
\hline May & 3,447 & 88 & 0 & 0 & 3,479 & 88 & 0 & 0 \\
\hline June & 3,355 & 85 & 0 & 0 & 3,387 & 86 & 0 & 0 \\
\hline July & 3,122 & 79 & 11 & 1.0 & 3,152 & 80 & 8 & .7 \\
\hline December & 2,371 & 60 & 43 & 4.0 & 2,398 & 61 & 31 & 2.9 \\
\hline Average & 2,882 & 73 & 28 & 2.6 & 2,916 & 74 & 22 & 2.1 \\
\hline
\end{tabular}

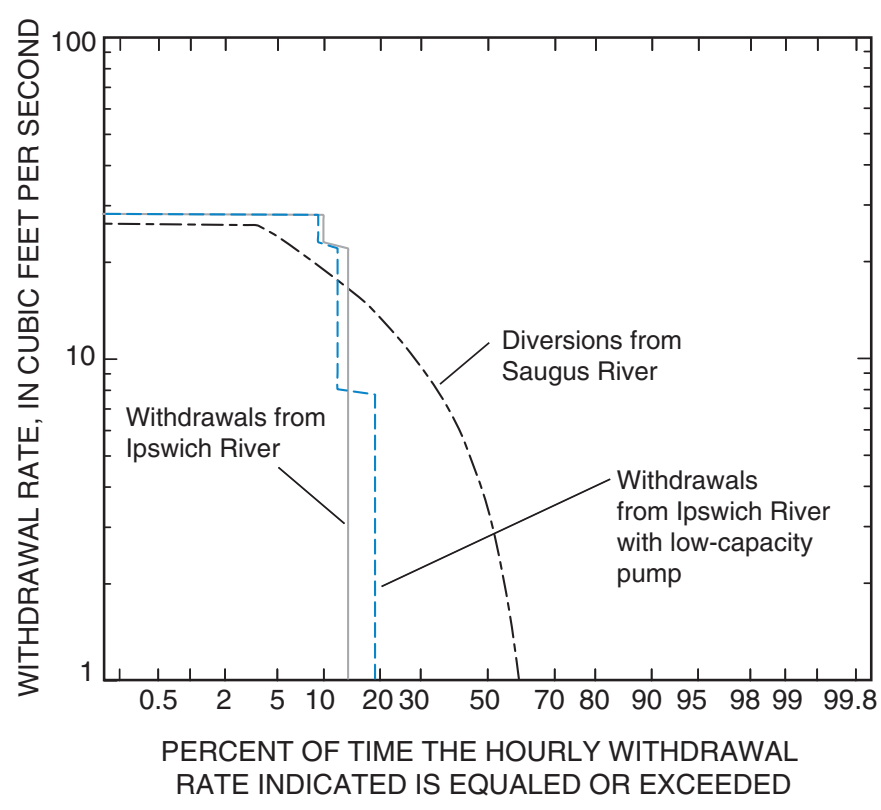

Figure 7. Withdrawal-duration curves simulated under average 1998-2000 demands (10.6 million gallons per day) and 2003 permitted withdrawals from the Ipswich River and Instream Flow Incremental Methodology (IFIM) recommended flow for the Saugus River, Lynn water-supply system, Massachusetts, 1961-95.
Streamflow-duration curves for the Ipswich River at the Lynn intake indicate only slightly less flow below the 50-percent flow duration than simulations with no withdrawals (fig. 8A). Streamflow-duration curves for the Saugus River at the Lynn diversion indicate that withdrawals appreciably affect streamflow (fig. $8 B$ ) below the 75-percent flow duration. Withdrawals from the Saugus River cause flows between the 10- and 50-percent flow duration to be about 2 to 3 times less than the simulated flow without withdrawals.

The firm yield for the Lynn system under the 2003 permitted withdrawals was $8.59 \mathrm{Mgal} / \mathrm{d}$. This value is 19 percent less than the average 1998-2000 demands (10.6 Mgal/d) and is similar to the previously simulated firm yield for the hypothetical flow restrictions for Ipswich River withdrawals and the IFIM flow restrictions for Saugus River diversions (Zarriello, 2002). This result indicates that the firm yield of the Lynn system is largely controlled by the restrictions placed on the Saugus River diversions. Streamflow prior to January 13, 1967 (when storage was at its minimum), indicated that the lowest pumping rate $(14 \mathrm{Mgal} / \mathrm{d})$ could be supported at the 2003 permitted-flow threshold for only 2 days between April 1, 1966 and January 13, 1967. Flow thresholds previously simulated in the hypothetical restrictions (Zarriello, 2002) were the same as the 2003 permitted withdrawals from November through February $\left(1.0 \mathrm{ft}^{3} / \mathrm{s} / \mathrm{mi}^{2}\right)$. The lower June through October streamflow threshold $\left(0.49 \mathrm{ft}^{3} / \mathrm{s} / \mathrm{mi}^{2}\right)$ simulated previously (Zarriello, 2002) did not allow for any additional withdrawals at the present pump rates during the summer period prior to February 1967, however. 


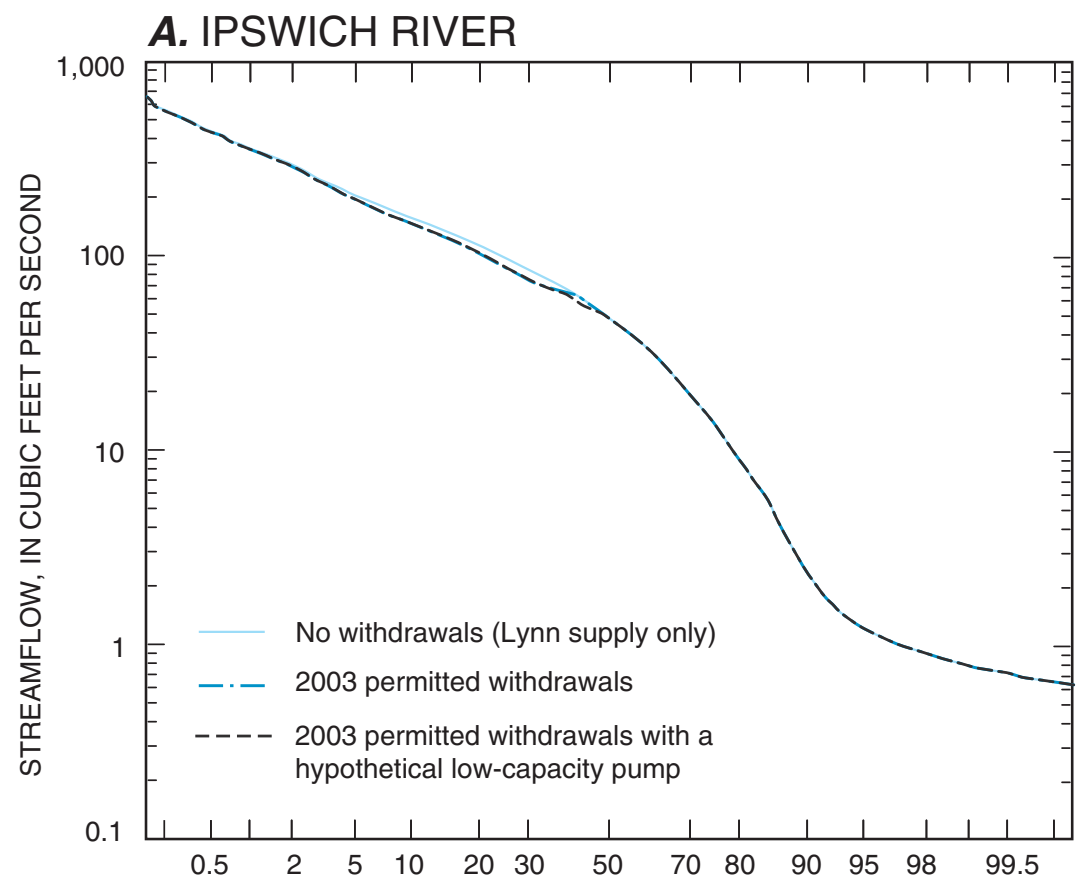

\section{B. SAUGUS RIVER}

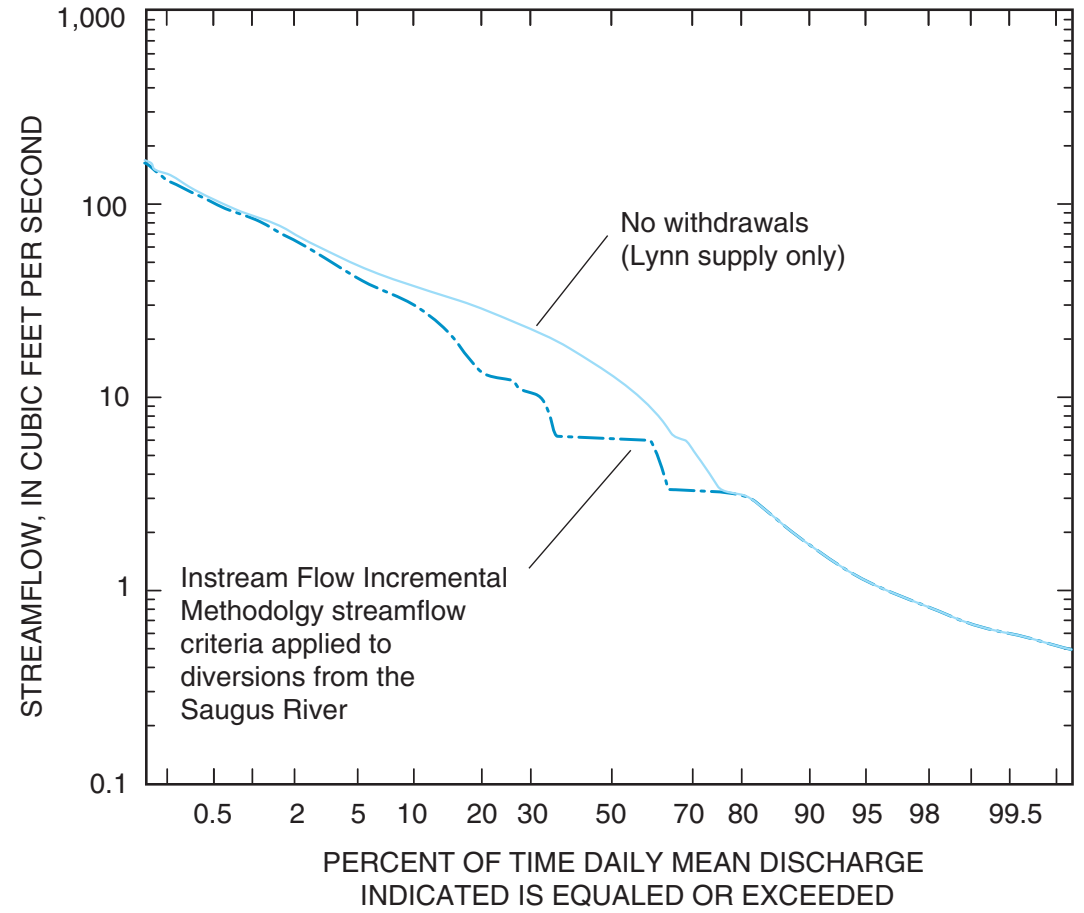

Figure 8. Daily mean streamflow-duration curves simulated under no withdrawals, under average 1998-2000 demands (10.6 million gallons per day) and 2003 permitted withdrawals at the intake on the $A$, Ipswich River (model reach 18), and under Instream Flow Incremental Methodology (IFIM) recommended flows at the diversion from $B$, Saugus River (model reach 90), Lynn water-supply system, Massachusetts, 1961-95. 
At the $8.59 \mathrm{Mgal} / \mathrm{d}$ demand rate, storage in the Lynn reservoir was at its minimum (1.9 percent of capacity) on January 13, 1967 (fig. 9); storage was at its second lowest level, outside of this period, on November 16, 1981 (21 percent of capacity). The mean monthly reservoir storage at the $8.59 \mathrm{Mgal} / \mathrm{d}$ withdrawal rate averaged 83 percent of capacity; the mean monthly storage was lowest in November (averaged 69 percent of capacity) and highest in April (averaged 95 percent of capacity). Annual withdrawals from the Ipswich River averaged $2.85 \mathrm{ft}^{3} / \mathrm{s}(1.84 \mathrm{Mgal} / \mathrm{d})$ and ranged from 0.02 to $4.56 \mathrm{ft}^{3} / \mathrm{s}$ (0.01 to $\left.2.95 \mathrm{Mgal} / \mathrm{d}\right)$. The highest annual withdrawal volume was equal to the annual volume restriction $(1,076 \mathrm{Mgal} / \mathrm{yr})$ in 6 of 35 years, which indicates that withdrawals in these years were limited by the annual volume cap.

The firm yield for the Lynn system under the 2003 permitted withdrawals with a hypothetical (5 Mgal/d) low-capacity pump was $8.90 \mathrm{Mgal} / \mathrm{d}$, which is an increase of $0.31 \mathrm{Mgal} / \mathrm{d}$ in the firm-yield rate simulated with the present pumps. The firm yield with the low-capacity pump is 16 percent less than Lynn's average 1998-2000 demands. At the $8.90 \mathrm{Mgal} / \mathrm{d}$ demand rate, storage in the Lynn reservoir was at its minimum (1.4 percent of capacity) on January 9, 1967, and was at its second lowest level, outside of this period, on November 16, 1981 (18 percent of capacity). Monthly reservoir storage averaged 82 percent of capacity; the mean monthly storage was lowest in November (averaged 68 percent of capacity) and highest in April (averaged 94 percent of capacity). Annual withdrawals from the Ipswich River averaged $3.15 \mathrm{ft}^{3} / \mathrm{s}(2.04 \mathrm{Mgal} / \mathrm{d})$ and ranged from 0.19 to $4.56 \mathrm{ft}^{3} / \mathrm{s}(0.12$ to $2.95 \mathrm{Mgal} / \mathrm{d})$. On average, withdrawals from the Ipswich River increased by about 7 percent with the addition of a low-capacity pump. The annual volume restriction limited withdrawal in the same 6 years simulated at the firm-yield withdrawal rate without the low-capacity pumps.

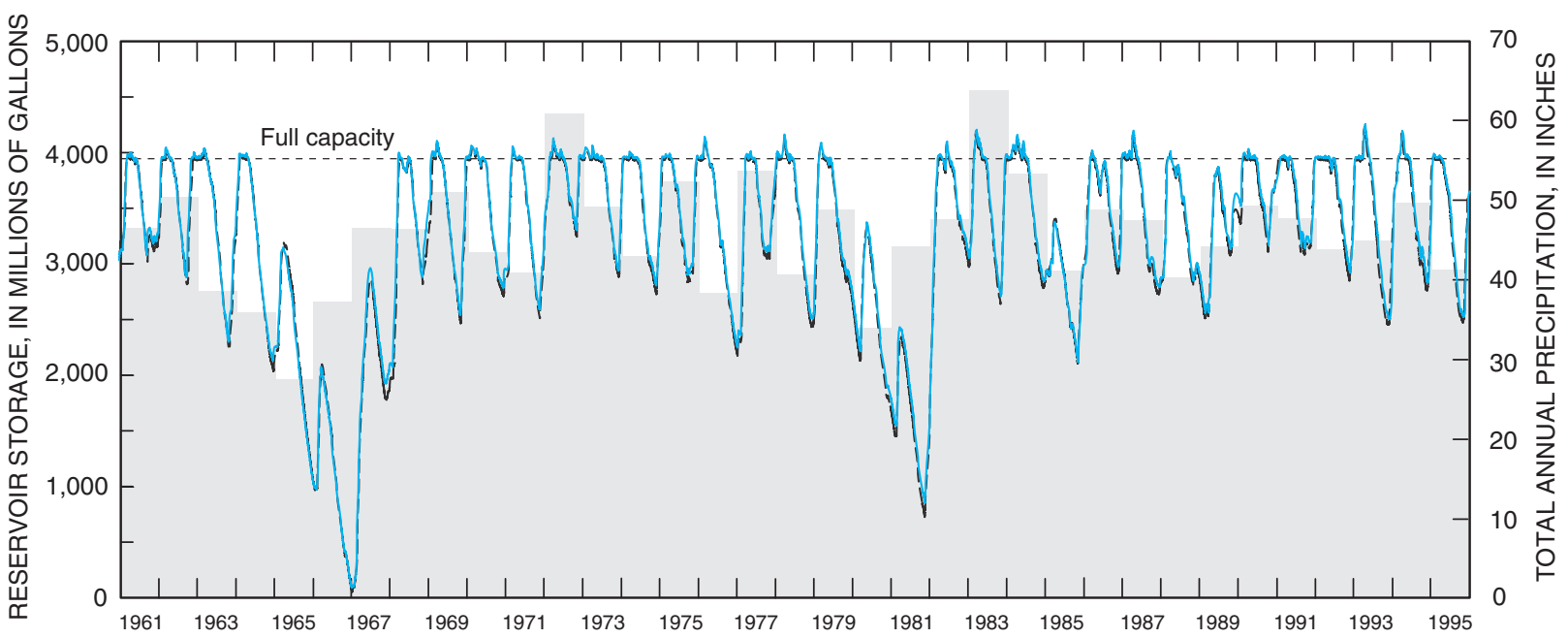

EXPLANATION

TOTAL ANNUAL PRECIPITATION

2003 PERMITTED WITHDRAWALS

(average withdrawal rate 7.31 million gallons per day)

- - - 2003 PERMITTED WITHDRAWALS WITH A LOW-CAPACITY PUMP

(average withdrawal rate 7.53 million gallons per day)

Figure 9. Daily mean reservoir storage simulated at the firm-yield demand rate under 2003 permitted withdrawals from the Ipswich River and Instream Flow Incremental Methodology (IFIM) recommended flows from the Saugus River and under the same streamflow criteria with a hypothetical low-capacity pump, Lynn water-supply system, Massachusetts, 1961-95. 


\section{Peabody System}

Simulation results under the 2003 permitted withdrawals and average 1998-2000 demands (5.9 Mgal/d) indicate that reservoir storage was depleted in all, but one year during the 35 year simulation period (fig. 10A). Reservoir storage was able to recover to 80 percent of capacity or more in 28 of 35 years and refill to capacity in 8 years, but generally for a short period of time. In the droughts of 1965-66 and 1980-81, the maximum annual storage averaged 42 percent of capacity. The lowest maximum annual storage occurred during 1981 and 1985, which recovered to only 31 percent of capacity. Precipitation in 1981 was the second lowest and 1985 was the 10th lowest annual total for the 1961-95 period. The reservoir storage was not able to recover in the spring of 1985 because withdrawals in the previous year stopped in early April when the maximum annual volume was reached. Withdrawals were not able to resume for nearly 8 months until January 1, 1985, causing below normal storage for this time of year. When withdrawals resumed on January 1, 1985, streamflow through May of 1985 was insufficient to sustain large withdrawals, thus causing the lowest simulated storage in the 35-year period. The duration curve of daily mean reservoir storage (fig. $10 B$ ) indicates that storage was depleted about 25 percent of the time, and storage was less than 25 percent of capacity about 50 percent of the time. Simulation results with the hypothetical low-capacity pump are nearly identical to the simulation results without the low-capacity pump.

Annual reservoir storage under the 2003 permitted withdrawals averaged $438 \mathrm{Mgal}$ or about 35 percent of capacity. The average monthly reservoir storage (fig. 11 and table 6) was lowest in November and December (averaged about 2 and 3 percent of capacity, respectively) and highest in April (averaged 80 percent of capacity). The average monthly reservoir storage was lowest following the period when withdrawals were restricted to flows above $141 \mathrm{ft}^{3} / \mathrm{s}$ at South Middleton station. Peabody's average annual reservoir storage was slightly higher (5 Mgal), but average withdrawals in April, May, and June were lower (7, 5, and $1 \mathrm{Mgal}$, respectively) with the simulation of a low-capacity pump because Lynn, whose withdrawals were also simulated with a low-capacity pump, obtained more water than previously simulated without the low-capacity pump.

Under the simulated conditions, Peabody withdrew water from the Ipswich River about 25 percent of the time under the 2003 permitted withdrawals (fig. 12). Withdrawals from the Ipswich River were made at the maximum pumping rate of $18 \mathrm{Mgal} / \mathrm{d}\left(28 \mathrm{ft}^{3} / \mathrm{s}\right)$ about 17 percent of the time; withdrawals at the $11 \mathrm{Mgal} / \mathrm{d}\left(17 \mathrm{ft}^{3} / \mathrm{s}\right)$ and the $4 \mathrm{Mgal} / \mathrm{d}\left(6.2 \mathrm{ft}^{3} / \mathrm{s}\right)$ pumping rates were made about 5 and 2 percent of the time, respectively. The annual withdrawals from the Ipswich River averaged $6.05 \mathrm{ft}^{3} / \mathrm{s}(3.91 \mathrm{Mgal} / \mathrm{d})$. During 21 of 35 years, the annual withdrawals were at or near the annual volume limit (1,500 Mgal). Withdrawals were not restricted by the annual volume limit in years with below-normal precipitation because in these years, withdrawals were limited by streamflow criteria. The simulations with the low-capacity pump indicated that withdrawals from the Ipswich River decreased slightly (averaged 3.84 Mgal/yr). The annual volume of water withdrawn from the Ipswich River decreased in years that were not limited by the annual volume limit; these were drought years, particularly 1965-66 and 1980, when withdrawals averaged about 4 percent less than the simulated withdrawals without the low-capacity pump. Again, this result reflects the increased upstream withdrawals by Lynn simulated with a low-capacity pump.

Streamflow-duration curves for the Ipswich River at the Peabody intake indicate that withdrawals under the 2003 permitted withdrawals do not appreciably affect streamflow above 50-percent flow duration (fig. 13). Simulated withdrawals for the Peabody water supply decrease streamflow by about a third between the 10- and 40-percent flow durations relative to simulations with no withdrawals. Withdrawals proportionally decrease relative to streamflow as flow increases; the present Peabody pumps can withdraw, at most, about 18 percent of the flow at the 10-percent flow duration, 14 percent of the flow at the 5-percent flow duration, and 9 percent of the flow at the 2-percent flow duration.

The firm yield for the Peabody system under the 2003 permitted withdrawals was $3.24 \mathrm{Mgal} / \mathrm{d}$. This value is 45 percent less than Peabody's average 1998-2000 demands (5.9 Mgal/d). At the $3.24 \mathrm{Mgal} / \mathrm{d}$ demand rate, storage in the Peabody reservoir was at its minimum (2.7 percent of capacity) on January 9, 1967 (fig. 14), and was at its second lowest level, outside of this period, on November 16, 1981 (4.2 percent of capacity). Mean monthly reservoir storage averaged 75 percent of capacity; the mean monthly storage was lowest in October and November (51 percent of capacity) and highest in April and May (96 percent of capacity). Annual withdrawals from the Ipswich River at the firm-yield rate averaged $3.80 \mathrm{ft}^{3} / \mathrm{s}(2.46$ $\mathrm{Mgal} / \mathrm{d})$ and ranged from 0.60 to $6.36 \mathrm{ft}^{3} / \mathrm{s}(0.39$ to $4.11 \mathrm{Mgal} / \mathrm{d}$, respectively). The highest annual withdrawal volume was equal to the annual volume restriction $(1,500 \mathrm{Mgal} / \mathrm{yr})$ in 2 of 35 years, which indicates that withdrawals were occasionally restricted by the annual volume limit. 

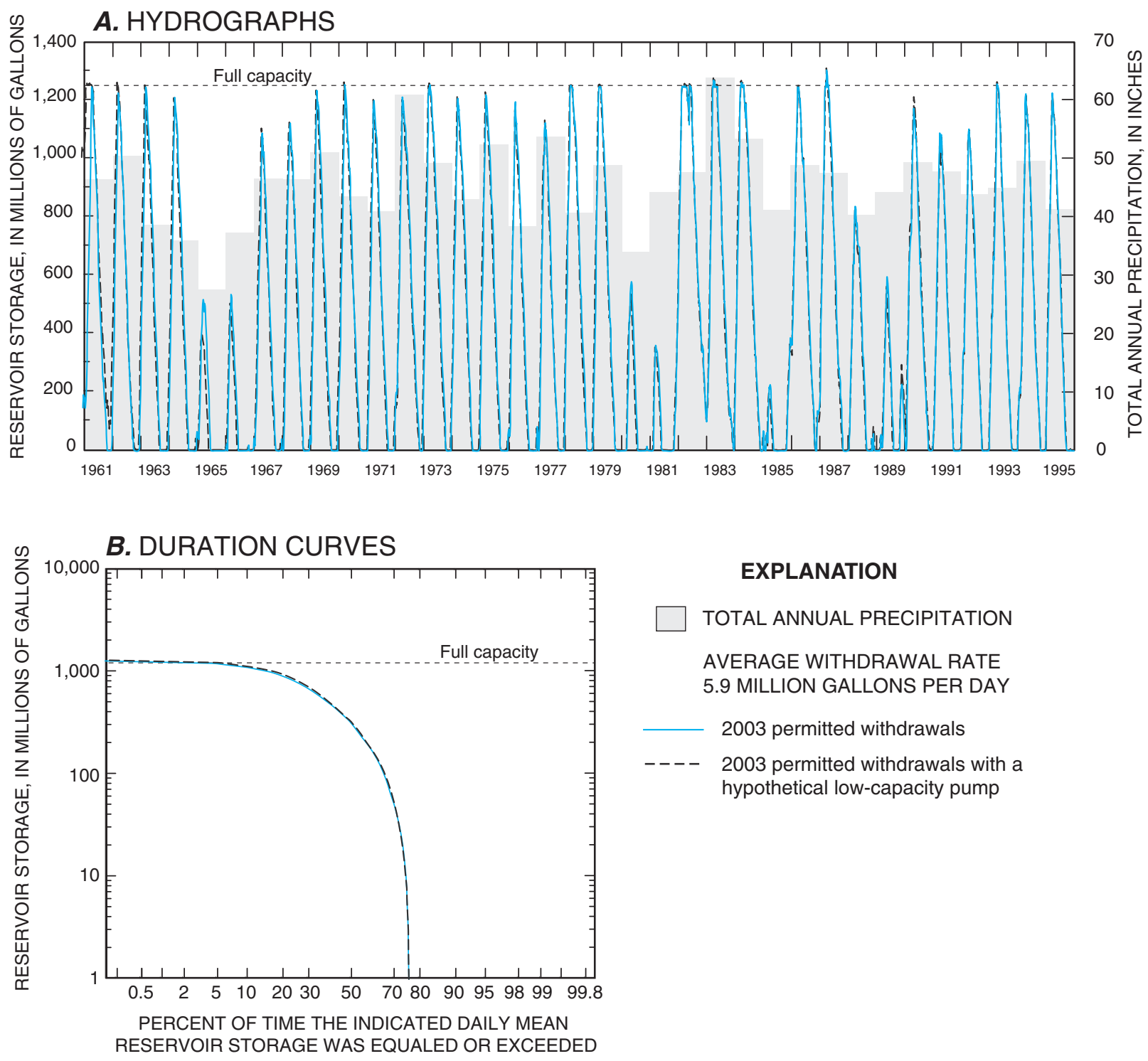

\section{EXPLANATION}

TOTAL ANNUAL PRECIPITATION

AVERAGE WITHDRAWAL RATE 5.9 MILLION GALLONS PER DAY

2003 permitted withdrawals

2003 permitted withdrawals with a hypothetical low-capacity pump

Figure 10. Daily mean reservoir storage $A$, hydrographs and $B$, duration curves simulated under average 1998-2000 demands and 2003 permitted withdrawals from the Ipswich River, Peabody water-supply system, Massachusetts, 1961-95. 


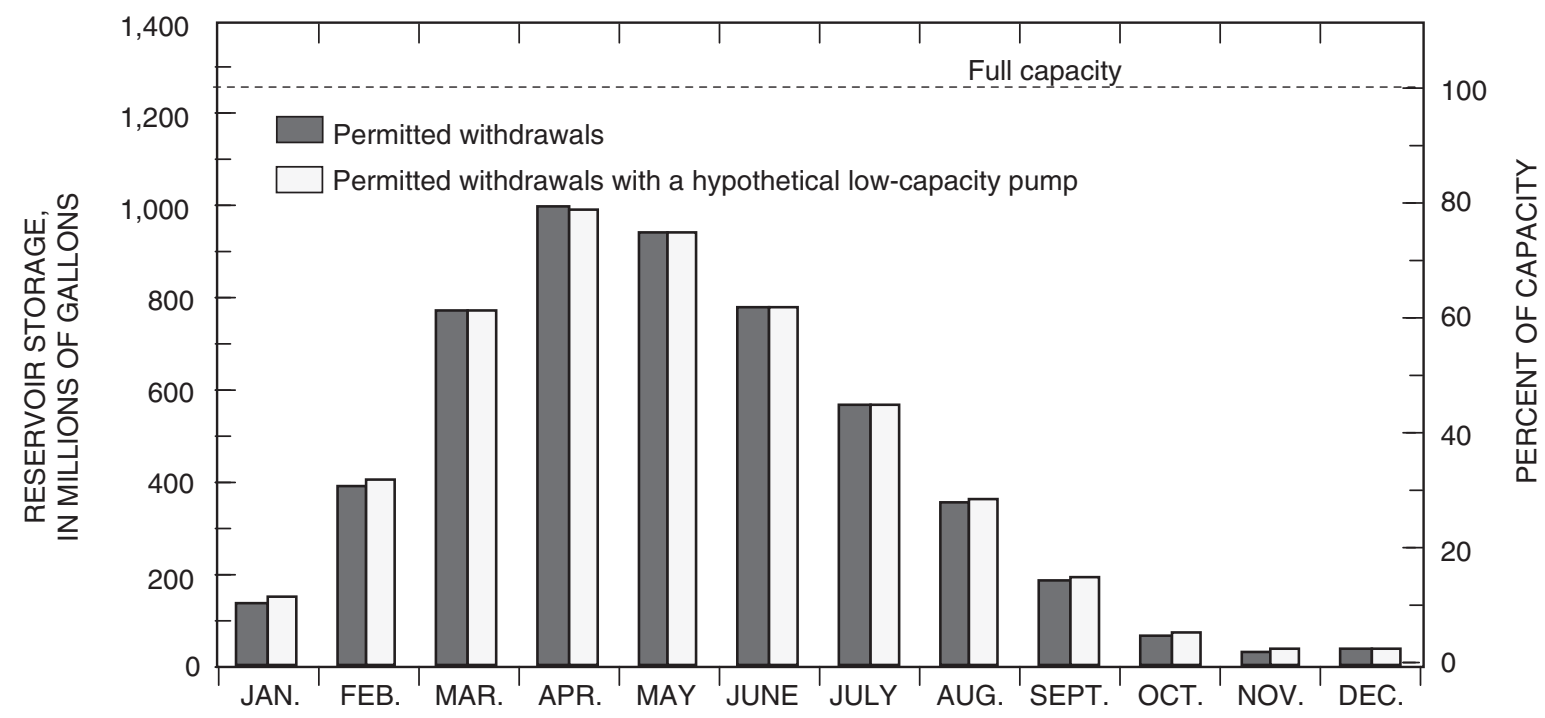

Figure 11. Average monthly reservoir storage simulated under average 1998-2000 demands (5.9 million gallons per day) and 2003 permitted withdrawals from the Ipswich River, Peabody water-supply system, Massachusetts, $1961-95$

Table 6. Average monthly reservoir storage and number of days during which the mean daily reservoir storage was depleted under average 1998-2000 demands (5.9 million gallons per day) and 2003 permitted withdrawals and under 2003 permitted withdrawals with a hypothetical low-capacity pump, Peabody water-supply system, Massachusetts, 1961-95.

[Total number of days storage depleted: Includes any day the minimum reservoir storage was zero. Mgal, million gallons]

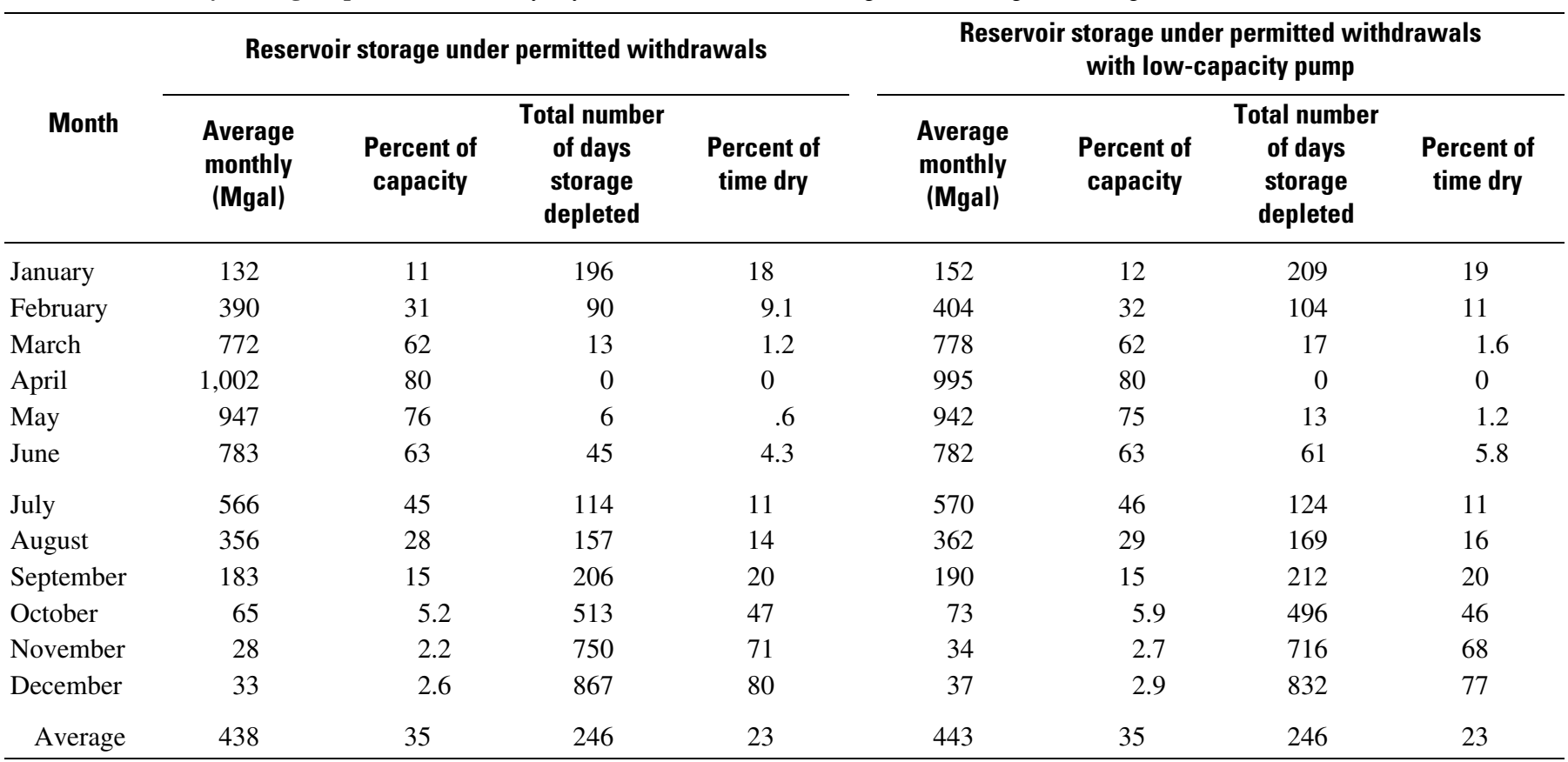




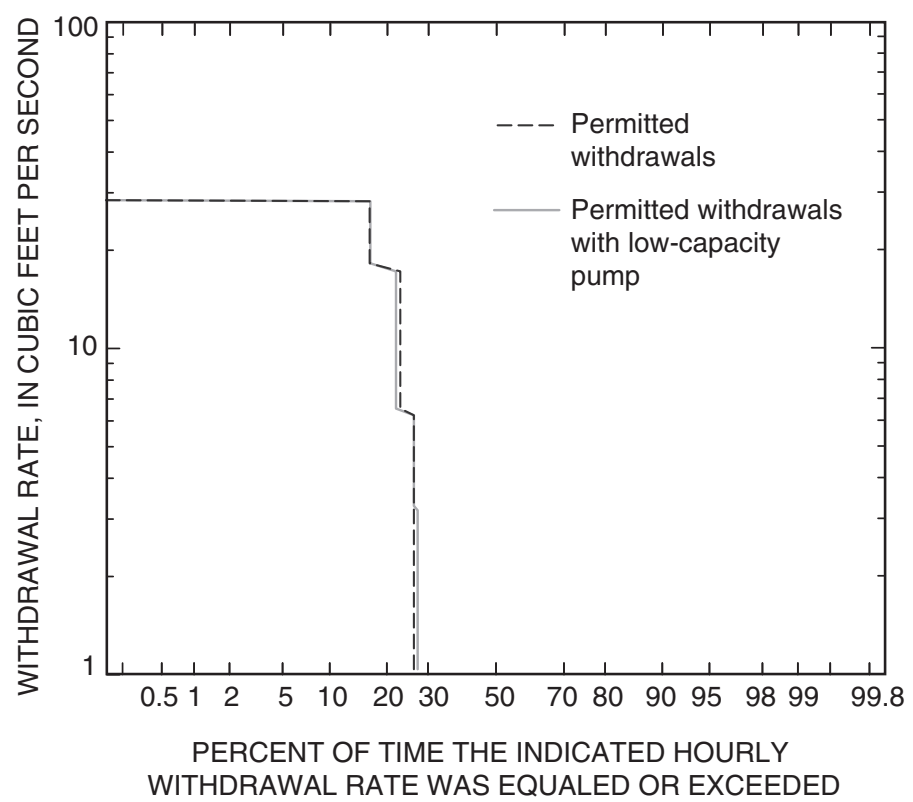

Figure 12. Withdrawal-duration curves from the Ipswich River (model reach 20) simulated under average 1998-2000 demands (5.9 million gallons per day) and 2003 permitted withdrawals, Peabody water-supply system, Massachusetts, 1961-95 (reach location shown in fig. 1).

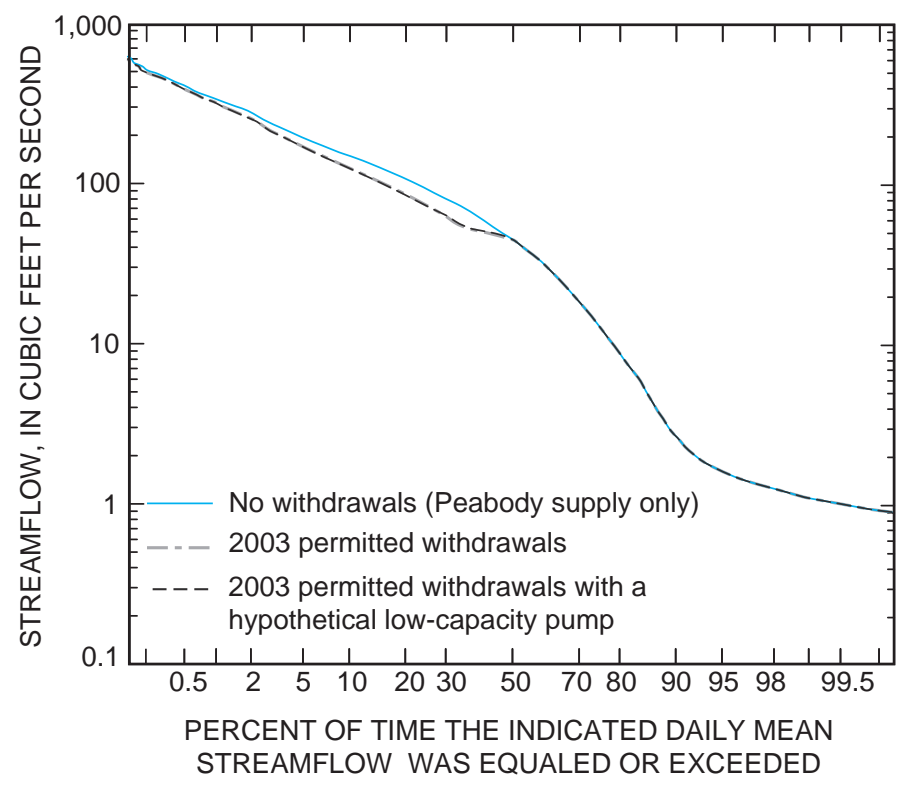

Figure 13. Daily mean streamflow-duration curves simulated under no withdrawals and under average 1998-2000 demands (5.9 million gallons per day) and 2003 permitted withdrawals at the intake location on the Ipswich River (model reach 20), Peabody water-supply system, Massachusetts, 1961-95 (reach location shown in fig. 1).
The firm yield for the Peabody system under the 2003 permitted withdrawals with a hypothetical $(2 \mathrm{Mgal} / \mathrm{d})$ lowcapacity pump was $3.07 \mathrm{Mgal} / \mathrm{d}$, which is a decrease of $0.17 \mathrm{Mgal} / \mathrm{d}$ in the firm yield simulated with the present pumps. This decrease in yield results from the additional water obtained by a low-capacity pump that was simultaneously simulated in the Lynn system (upstream), and because the contributing area between the Lynn and Peabody intakes is less than $2 \mathrm{mi}^{2}$. The firm yield is 48 percent less than Peabody's average 1998-2000 demands. At the $3.07 \mathrm{Mgal} / \mathrm{d}$ demand rate, storage in the Peabody reservoir was at its minimum ( 0.9 percent of capacity) on January 9, 1967, and was at its second lowest level, outside of this period, on November 15-16, 1981 (11 percent of capacity). Monthly reservoir storage at the $3.07 \mathrm{Mgal} / \mathrm{d}$ demand rate averaged 76 percent of capacity; mean monthly storage was lowest in October and November (53 percent of capacity) and largest in April and May (95 percent of capacity). Annual withdrawals from the Ipswich River at the firm-yield rate averaged $3.53 \mathrm{ft}^{3} / \mathrm{s}(2.28 \mathrm{Mgal} / \mathrm{d})$ and ranged from 0.55 to $6.36 \mathrm{ft}^{3} / \mathrm{s}(0.36$ to $4.11 \mathrm{Mgal} / \mathrm{d})$. On average, the Peabody system withdrawals from the Ipswich River decreased because of additional withdrawals obtained by the simulated low-capacity pump in the Lynn system. Simulated withdrawals were restricted by the annual volume limit in the same years as simulated without the low-capacity pump.

\section{Salem-Beverly System}

Simulation results under the 2003 permitted withdrawals and average 1998-2000 demands (10.1 Mgal/d) indicate that reservoir storage was depleted in 4 of 35 years (fig. 15A). Reservoir storage refilled to capacity during the winter-spring period during most years except for the droughts of 1965-66, 1980-81, 1985, and 1989. The lowest maximum annual storage was in 1966, which reached 38 percent of capacity. The duration curve of daily mean storage (fig. 15B) indicates that storage was depleted about 3 percent of the time and was less than 25 percent of capacity about 7 percent of the time. Simulations with a hypothetical (10 Mgal/d) low-capacity pump indicate small additional gains in storage. The duration curve of daily mean reservoir storage (fig. $15 B$ ) indicates that with the $10 \mathrm{Mgal} / \mathrm{d}$ pump, storage was depleted about 2 percent of the time and was less than 25 percent of capacity about 6 percent of the time.

Annual reservoir storage under the permitted withdrawals averaged 2,612 Mgal or about 73 percent of capacity. The average monthly reservoir storage (fig. 16; table 7) was lowest in October and November (53 percent of capacity) and highest in April (93 percent of capacity). The average monthly reservoir storage was lowest following the period when withdrawals were restricted to flows above 381 $\mathrm{ft}^{3} / \mathrm{s}$ at the Ipswich station. Monthly storage averaged 53 Mgal more with the simulation 


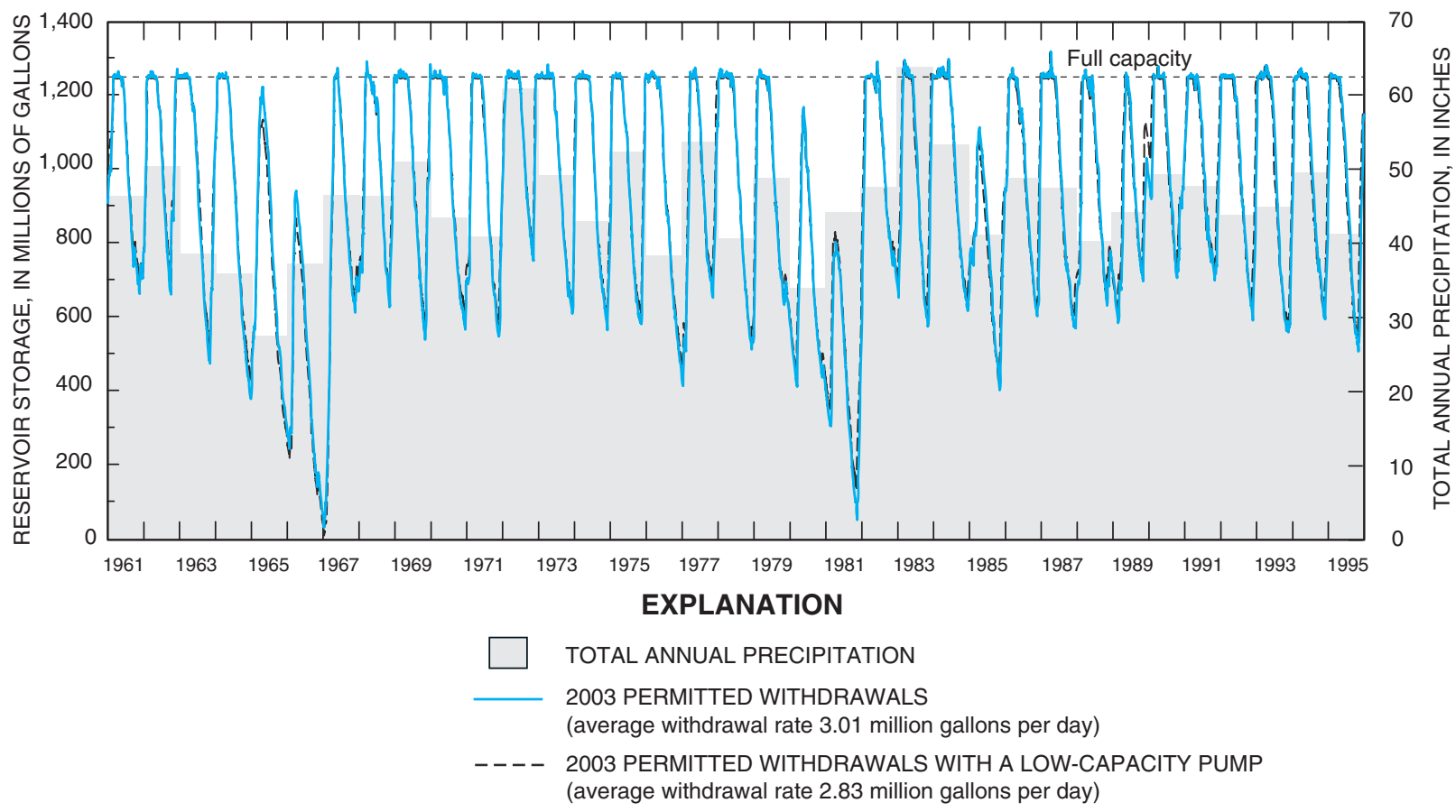

Figure 14. Daily mean reservoir storage simulated at firm-yield demand rates under 2003 permitted withdrawals and 2003 permitted withdrawals with a hypothetical low-capacity pump, Peabody water-supply system, Massachusetts, 1961-95.

of the low-capacity pump than without. The gain in monthly average storage ranged from $41 \mathrm{Mgal}$ in April to $78 \mathrm{Mgal}$ in January, which represents about 1 to 2 percent of the reservoir capacity, respectively.

Under the simulated 2003 permitted withdrawals, SalemBeverly withdrew water from the Ipswich River about 13 percent of the time (fig. 17). Withdrawals from the Ipswich River were about equally divided between the maximum pumping rate of $50 \mathrm{Mgal} / \mathrm{d}\left(77 \mathrm{ft}^{3} / \mathrm{s}\right)$ and the $25 \mathrm{Mgal} / \mathrm{d}$ (39 $\mathrm{ft}^{3} / \mathrm{s}$ ) pumping rate. The annual diversion from the Ipswich River was $7.58 \mathrm{ft}^{3} / \mathrm{s}(4.90 \mathrm{Mgal} / \mathrm{d})$ and ranged from 0.3 to $17 \mathrm{ft}^{3} / \mathrm{s}(0.19$ to $11 \mathrm{Mgal} / \mathrm{d})$. Withdrawals from the Ipswich River were least during years when the reservoir storage was high because of direct runoff. The annual volume restriction $(4,128 \mathrm{Mgal} / \mathrm{yr})$ limited withdrawals from the Ipswich River in 1967 and 1986. The simulation with the low-capacity pump indicated that water is withdrawn from the Ipswich River about 18 percent of the time (fig. 17) and withdrawals at the $25 \mathrm{Mgal} / \mathrm{d}$ and $50 \mathrm{Mgal} / \mathrm{d}$ rates were slightly less than in simulations without the low-capacity pump. The slight decrease in the higher pump rates is attributed to the low-capacity pump maintaining storage near capacity, thus decreasing the need to pump at the higher rates to satisfy the storage deficit.

Streamflow-duration curves for the Ipswich River at the Salem-Beverly intake (RCHRES 43) indicate that withdrawals do not appreciably affect streamflow above the 50-percent flow duration (fig. 18). Simulated streamflows between the 10 and 40-percent flow duration decrease by about one-quarter under permitted withdrawals for the Salem-Beverly water supply. 


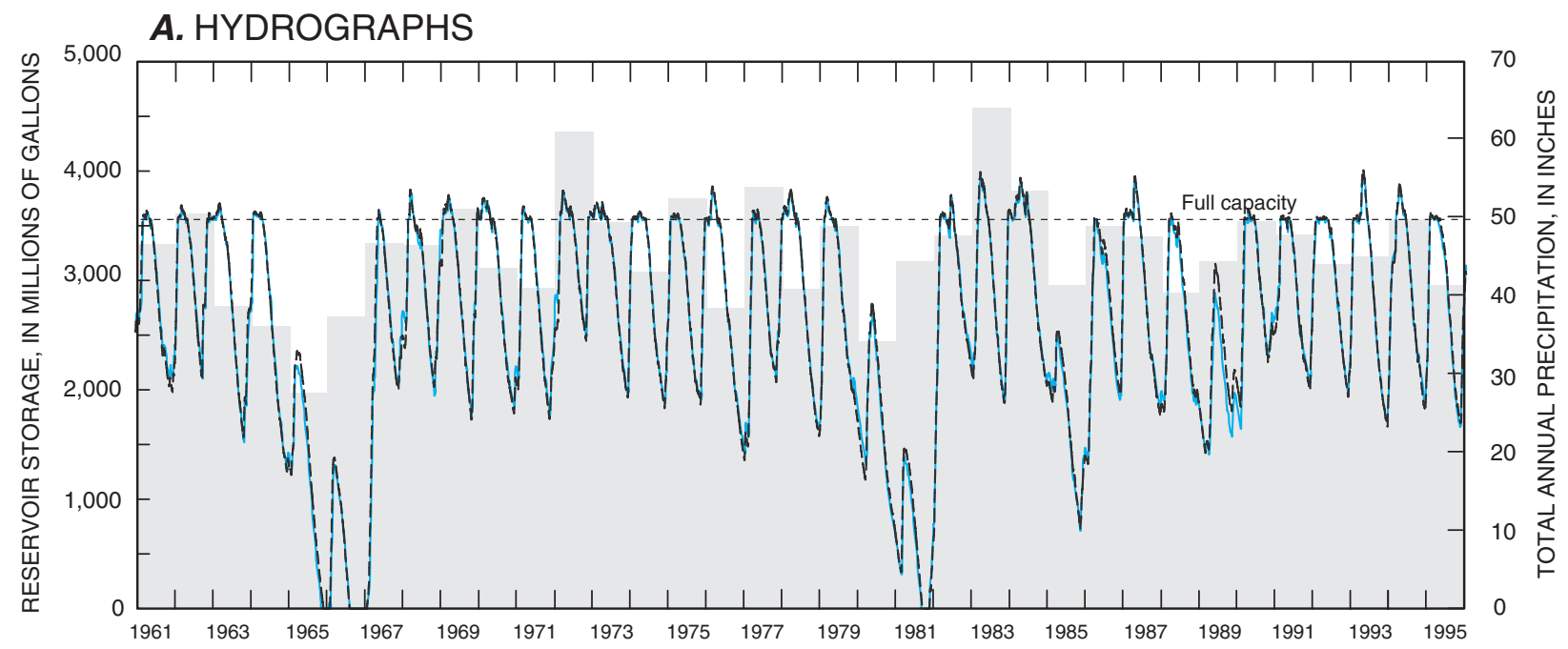

\section{B. DURATION CURVES}

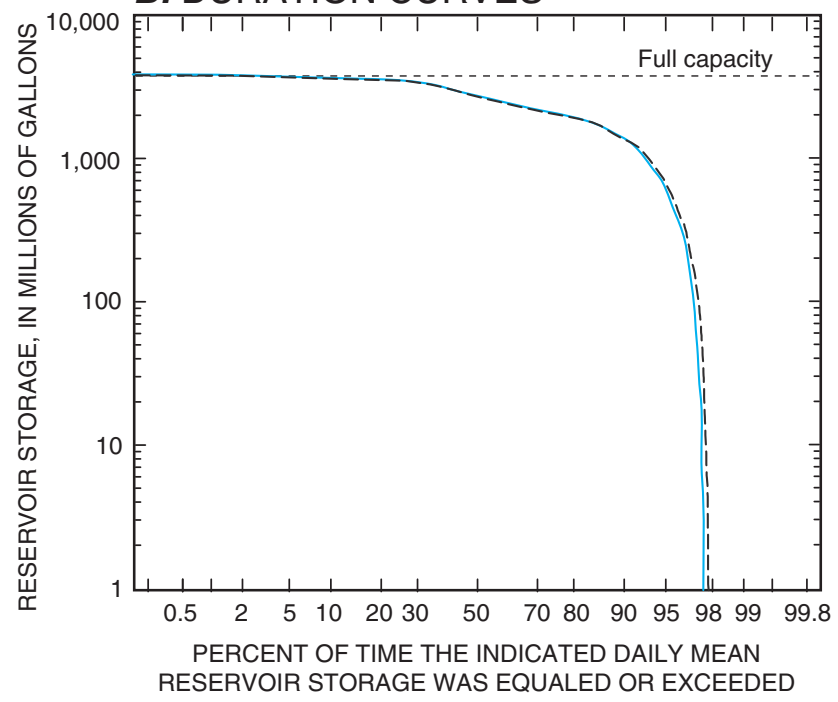

\section{EXPLANATION}

TOTAL ANNUAL PRECIPITATION

AVERAGE WITHDRAWAL RATE 10.1 MILLION GALLONS PER DAY

2003 permitted withdrawals

2003 permitted withdrawals with a hypothetical low-capacity pump

Figure 15. Daily mean reservoir storage $A$, hydrographs and $B$, duration curves simulated under average 1998-2000 demands and 2003 permitted withdrawals from the Ipswich River, Salem-Beverly water-supply system, Massachusetts, 1961-95. 


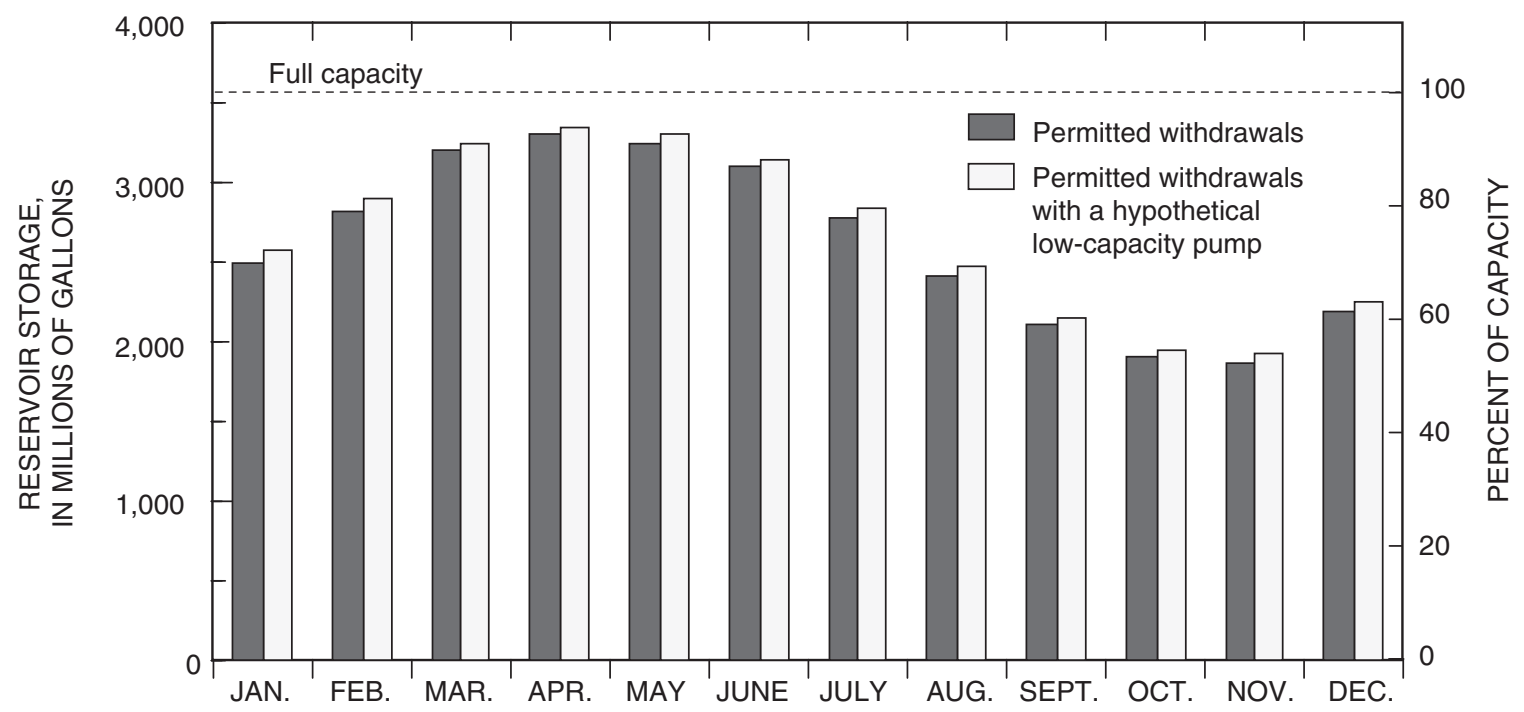

Figure 16. Average monthly reservoir storage simulated under average 1998-2000 demands (10.1 million gallons per day) and 2003 permitted withdrawals from the Ipswich River, Salem-Beverly water-supply system, Massachusetts, 1961-95.

Table 7. Average monthly reservoir storage and number of days during which the mean daily reservoir storage was depleted under average 1998-2000 demands (10.1 million gallons per day) and 2003 permitted withdrawals and under 2003 permitted withdrawals with a hypothetical low-capacity pump, Salem-Beverly water-supply system, Massachusetts, 1961-95.

[Total number of days storage depleted: Includes any day the minimum reservoir storage was zero. Mgal, million gallons]

\begin{tabular}{|c|c|c|c|c|c|c|c|c|}
\hline \multirow[b]{2}{*}{ Month } & \multicolumn{4}{|c|}{ Reservoir storage under permitted withdrawals } & \multicolumn{4}{|c|}{$\begin{array}{c}\text { Reservoir storage under permitted withdrawals } \\
\text { with low-capacity pump }\end{array}$} \\
\hline & $\begin{array}{c}\text { Average } \\
\text { monthly } \\
\text { (Mgal) }\end{array}$ & $\begin{array}{l}\text { Percent of } \\
\text { capacity }\end{array}$ & $\begin{array}{c}\text { Total number } \\
\text { of days } \\
\text { storage } \\
\text { depleted }\end{array}$ & $\begin{array}{l}\text { Percent of } \\
\text { time dry }\end{array}$ & $\begin{array}{c}\text { Average } \\
\text { monthly } \\
\text { (Mgal) }\end{array}$ & $\begin{array}{l}\text { Percent of } \\
\text { capacity }\end{array}$ & $\begin{array}{c}\text { Total number } \\
\text { of days } \\
\text { storage } \\
\text { depleted }\end{array}$ & $\begin{array}{l}\text { Percent of } \\
\text { time dry }\end{array}$ \\
\hline January & 2,491 & 70 & 50 & 4.6 & 2,569 & 72 & 42 & 3.9 \\
\hline March & 3,196 & 90 & 0 & 0 & 3,238 & 91 & 0 & 0 \\
\hline April & 3,291 & 93 & 0 & 0 & 3,332 & 94 & 0 & 0 \\
\hline May & 3,239 & 91 & 0 & 0 & 3,290 & 93 & 0 & 0 \\
\hline June & 3,088 & 87 & 0 & 0 & 3,141 & 88 & 0 & 0 \\
\hline July & 2,772 & 78 & 0 & 0 & 2,824 & 79 & 0 & 0 \\
\hline November & 1,869 & 53 & 56 & 5.3 & 1,916 & 54 & 43 & 4.1 \\
\hline December & 2,176 & 61 & 62 & 5.7 & 2,239 & 63 & 31 & 2.9 \\
\hline Average & 2,612 & 73 & 25 & 2.4 & 2,665 & 75 & 18 & 1.7 \\
\hline
\end{tabular}




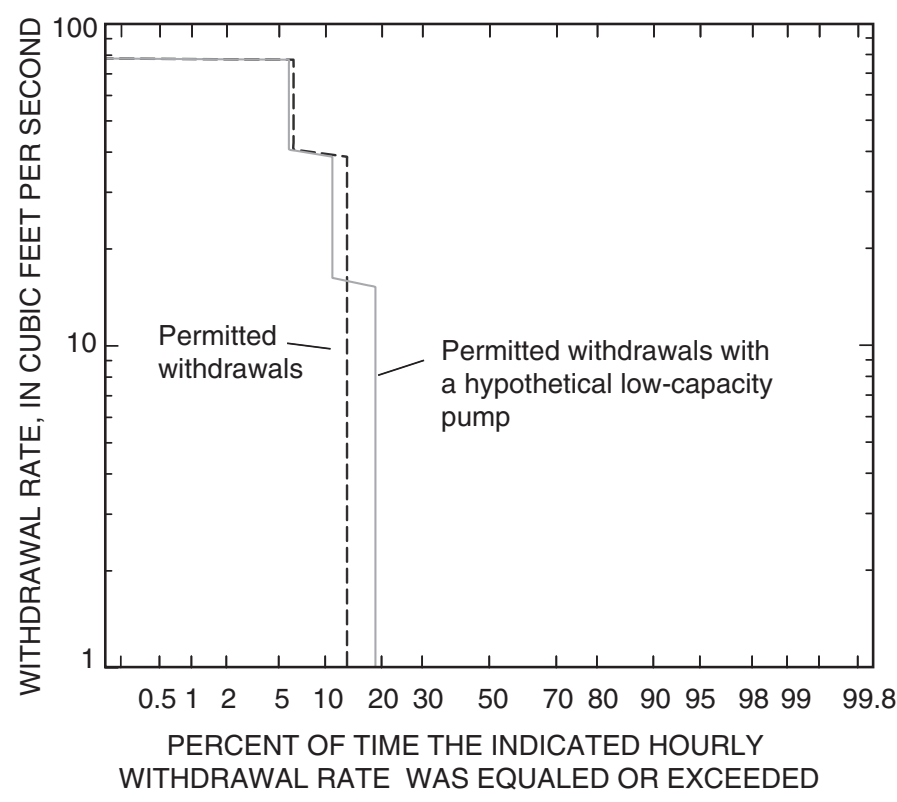

Figure 17. Withdrawal-duration curves from the Ipswich River (model reach 43) simulated under average 1998-2000 demands (10.1 million gallons per day) and 2003 permitted withdrawals, Salem-Beverly water-supply system, Massachusetts, 1961-95 (reach location shown in fig. 1).

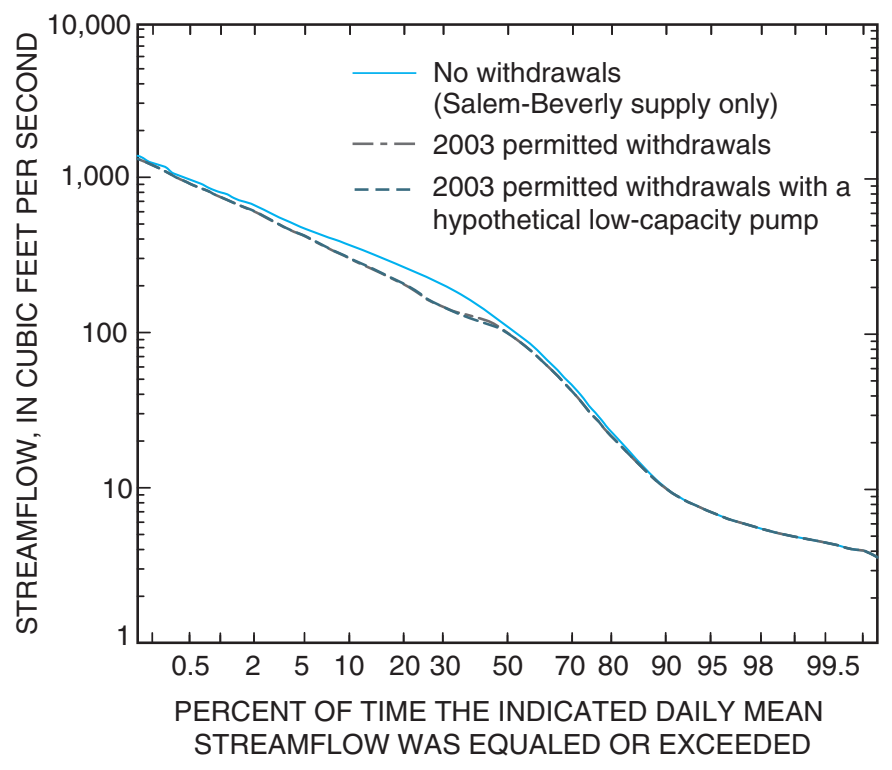

Figure 18. Daily mean streamflow-duration curves simulated under no withdrawals and under average 1998-2000 demands (10.1 million gallons per day) and 2003 permitted withdrawals at the intake location on the Ipswich River (model reach 43), SalemBeverly water-supply system, Massachusetts, 1961-95 (reach location shown in fig. 1).
The firm yield for the Salem-Beverly system under the 2003 permitted withdrawals was $8.38 \mathrm{Mgal} / \mathrm{d}$. This value is 17 percent less than the average 1998-2000 demand $(10.1 \mathrm{Mgal} / \mathrm{d})$. At the $8.38 \mathrm{Mgal} / \mathrm{d}$ demand rate, storage in the Salem-Beverly reservoir was at its minimum $(0.2$ percent of capacity) on February 2, 1967 (fig. 19), and was at its second lowest level, outside of this period, on November 15, 1981 (26 percent of capacity). Mean monthly reservoir storage averaged 81 percent of capacity and was lowest in October and November (64 percent of capacity) and highest in April (97 percent of capacity). Annual withdrawals from the Ipswich River at the firm-yield demand rate averaged 5.72 $\mathrm{ft}^{3} / \mathrm{s}(3.70 \mathrm{Mgal} / \mathrm{d})$ and ranged from 0.20 to $16.5 \mathrm{ft}^{3} / \mathrm{s}(0.13$ to $10.7 \mathrm{Mgal} / \mathrm{d})$. The highest annual withdrawal volume was less than the annual volume limit $(4,128 \mathrm{Mgal} / \mathrm{yr})$, thus withdrawals were not restricted by the annual volume cap.

The firm yield for the Salem-Beverly system under the 2003 permitted withdrawals with a hypothetical $(10 \mathrm{Mgal} / \mathrm{d})$ low-capacity pump was $8.79 \mathrm{Mgal} / \mathrm{d}$, which is an increase of $0.41 \mathrm{Mgal} / \mathrm{d}$ in the firm yield simulated with the existing pumps. The firm yield is about 13 percent less than SalemBeverly's average 1998-2000 demands. At the $8.79 \mathrm{Mgal} / \mathrm{d}$ demand rate, storage in the Salem-Beverly reservoir was at its minimum ( 2 percent of capacity) on January 28,1967 , and was at its second lowest level, outside of this period, on November 15-16, 1981 (22 percent of capacity). Monthly reservoir storage averaged 81 percent of capacity and was lowest in October and November (63 percent of capacity) and largest in April (97 percent of capacity). Annual withdrawals from the Ipswich River at the firm-yield demand rate with the low-capacity pump averaged $6.24 \mathrm{ft}^{3} / \mathrm{s}(4.03 \mathrm{Mgal} / \mathrm{d})$ and ranged from 0.4 to $16.9 \mathrm{ft}^{3} / \mathrm{s}(0.26$ to $10.9 \mathrm{Mgal} / \mathrm{d})$. On average, withdrawals from the Ipswich River increased by about 9 percent with the addition of a low-capacity pump. This simulation also includes upstream low-capacity pumps for Lynn and Peabody systems. Unlike Peabody, the yield for Salem-Beverly increased because the low-capacity pump can utilize water that is contributed by about $80 \mathrm{mi}^{2}$ of drainage area between the Peabody intake and the streamflow index station.

\section{Effects of Alternative Seasonal Streamflow Thresholds on Firm Yield (FY-IPR3)}

The 2003 permits recognized the need for additional information to achieve a balance between water supply and environmental concerns (Madelyn Morris, MDEP Deputy Region Director, Bureau of Resource Protection, written commun., May 19, 2003). MDEP needs this type of information to evaluate the tradeoff between streamflow thresholds and water supply and possibly to modify the streamflow criteria established in the 2003 permits. Seasonal streamflow thresholds, November through February and March through May, were independently increased and decreased in 20-percent increments from 0.2 to $1.8 \mathrm{ft} 3 / \mathrm{s} / \mathrm{mi}^{2}$ 


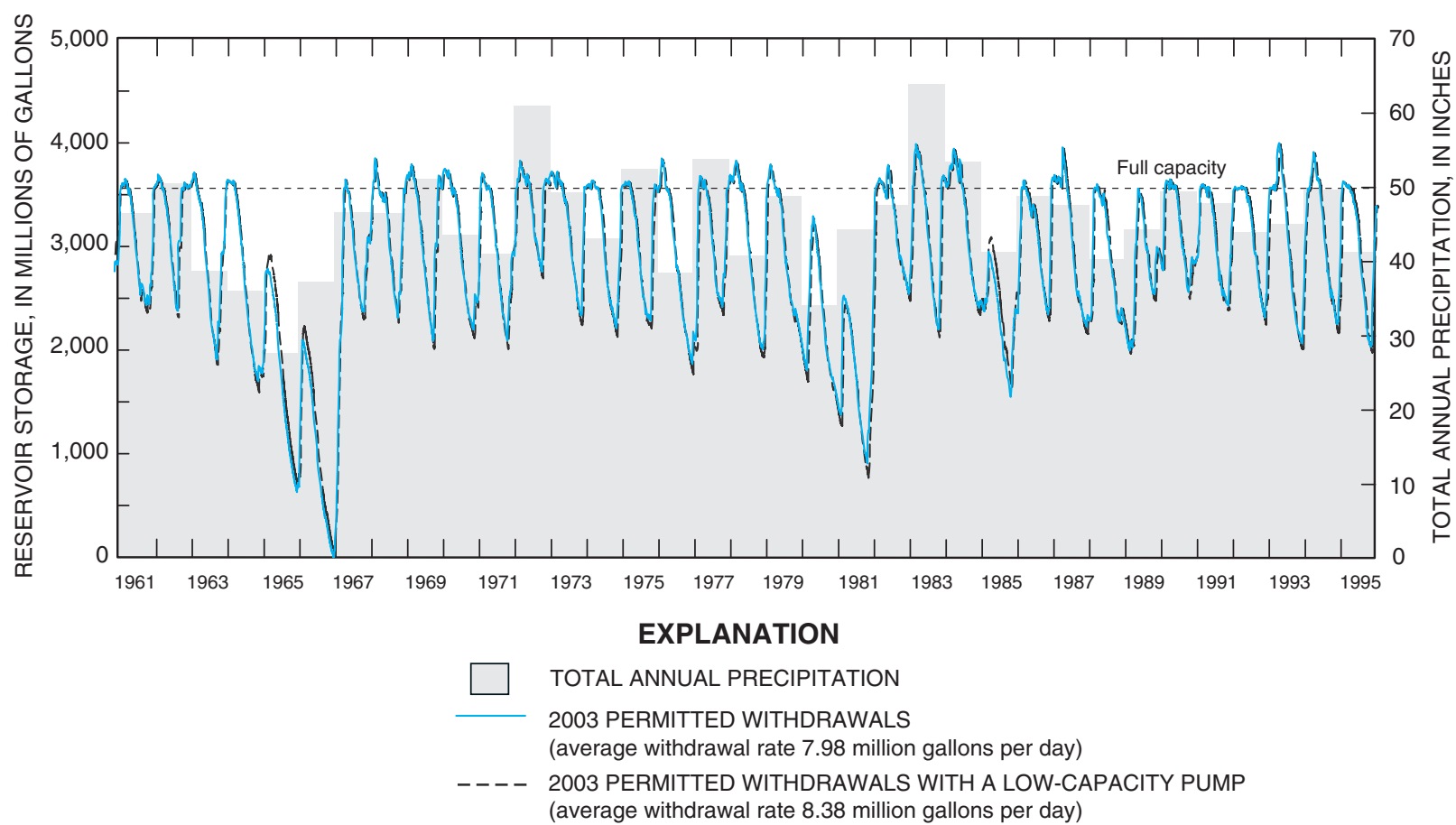

Figure 19. Daily mean reservoir storage simulated at firm-yield demand rates under 2003 permitted withdrawals and 2003 permitted withdrawals with a hypothetical low-capacity pump, Salem-Beverly water-supply system, Massachusetts, 1961-95.

( \pm 80 percent $)$ and the effect of each of these altered threshold values on the firm yield of each supply system was determined. The June through October threshold was decreased in 20percent increments to -80 percent, and the effect of each value on each system's firm yield was determined. The June through October streamflow threshold was only decreased because of the relatively high-flow thresholds established for this period in the 2003 permits. Annual withdrawal volume limits from the Ipswich River were removed to eliminate any effect these restrictions have on the firm yield. Alternative thresholds were applied to withdrawals from the Ipswich River and do not include alternative flow thresholds for Saugus River diversions for the Lynn system. Seasonal-flow threshold simulations are identified by the $u c i$ file name and IDSCEN attribute of FY-IPR3.

Changes in each system's firm yield that result from changes in the seasonal streamflow thresholds do not fully characterize the effect these threshold values have on water supply. For example, changes in the seasonal streamflow threshold could result in large changes in the average monthly reservoir storage and other characteristics that provide confidence in the system's ability to meet demands. The large number of simulations involved in the investigation of alternative seasonal streamflow thresholds necessitated limiting the simulations to about a 3-year period (January 1, 1964, through February 28, 1967). This simulation period provided at least one cycle of seasonal storage recovery before the reservoir systems failed; this provides a sufficient simulation period to remove any effects from the model starting conditions in the determination of the system's firm yield. Long-term storage characteristics could be calculated for each system if MDEP determines that other streamflow thresholds advance the balance between water supply and environmental concerns.

Changes in the November through February (fall-winter) and the March through May (spring) streamflow thresholds resulted in similar changes in the firm yield of the Lynn (fig. 20A), Peabody (fig. 20B), and Salem-Beverly (fig. 20C) systems. In all systems, the firm yield was generally about twice as sensitive to decreases then to increases in the fall-winter or spring thresholds. The firm yield was also generally slightly less sensitive to changes in the fall-winter threshold than to changes in the spring threshold in the Peabody and Salem-Beverly systems. Decreases in the June through October (summer) threshold had no effect on any of the systems' firm yields. This lack of effect indicates that summer flows prior to the reservoir failures were mostly insufficient to meet even the lowest flow threshold simulated ( 80 percent decrease from the permitted threshold). 


\section{A. LYNN WATER-SUPPLY SYSTEM}

FIRM YIELD, IN MILLIONS OF GALLONS PER DAY (Mgal/d)
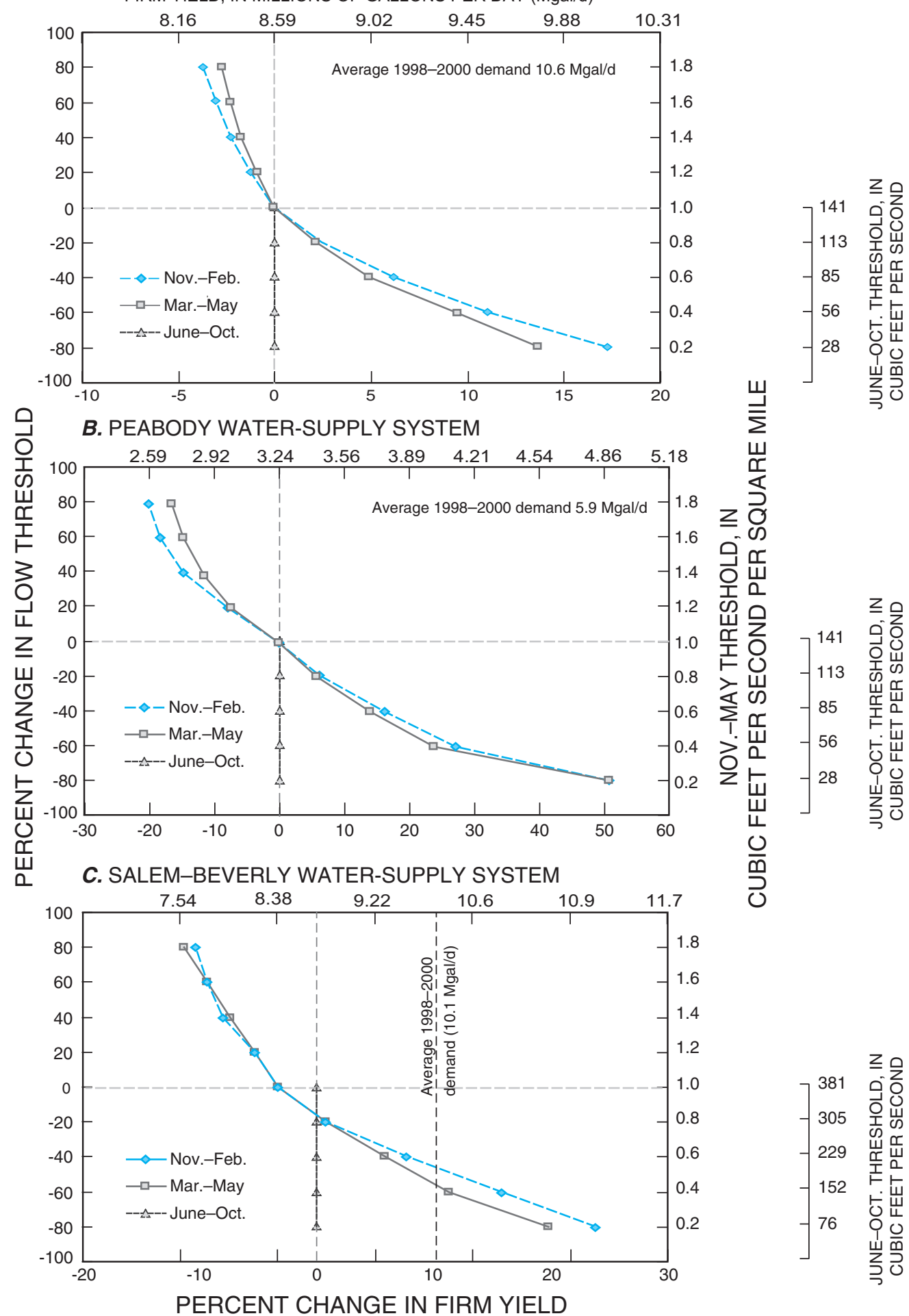

Figure 20. Changes in firm yield in response to changes in the seasonal streamflow threshold in the Ipswich River for $A$, Lynn; $B$, Peabody; and $C$, Salem-Beverly water-supply systems, Massachusetts. [Mgal/d, million gallons per day] 
Independently increasing the fall-winter or spring seasonal thresholds by 20 percent (to $1.2 \mathrm{ft}^{3} / \mathrm{s} / \mathrm{mi}^{2}$ ) decreased the firm yield of the Lynn, Peabody, and Salem-Beverly systems by 1,7 , and 2 percent, respectively. An increase of 80 percent (to $1.8 \mathrm{ft}^{3} / \mathrm{s} / \mathrm{mi}^{2}$ ) in either the fall-winter or spring threshold resulted in about a 3-, 18-, and 9-percent decrease in the firm yield of the Lynn, Peabody, and Salem-Beverly systems, respectively. Decreasing the fall-winter or spring seasonal threshold by 20 percent (to $0.8 \mathrm{ft}^{3} / \mathrm{s} / \mathrm{mi}^{2}$ ) resulted in about a 2-percent increase in the Lynn system firm yield and about an 5-percent increase in the Peabody and Salem-Beverly systems' firm yield. A decrease of 80 percent (to $0.2 \mathrm{ft}^{3} / \mathrm{s} / \mathrm{mi}^{2}$ ) in either the fall-winter or spring seasonal threshold resulted in relatively large increases in the firm yields of all systems. Decreasing the fall-winter or spring thresholds by 80 percent increased firm yields by 16,51 , and 30 percent in both seasonal changes in the Lynn, Peabody, and Salem-Beverly systems, respectively.

Simulations of alternative seasonal flow thresholds indicate that Lynn and Peabody cannot meet average 1998-2000 demands at the lowest thresholds (fig. 20A and 20B, respectively). Salem-Beverly was able to meet average 1998-2000 demands when the fall-winter threshold was decreased by about 45 percent or when the spring threshold was decreased by about 55 percent. Combined decreases in seasonal thresholds effect on the systems' firm yields are likely additive across seasons. Thus, Lynn and Peabody could possibly meet average 1998-2000 demands with about a 70 percent decrease in both fall-winter and spring flow thresholds. For example, for Lynn to meet average 1998-2000 demands would require a 23 percent increase in the firm yield. Split equally between fall-winter and spring thresholds would require a decrease in these seasonal flow thresholds of about 63 and 72 percent, respectively. The effects of concurrent seasonal changes on each system's firm yield can be interpolated from the graphs in figure 20 .

\section{System Yields at Successive Failures (FY-IPR4)}

Withdrawals authorized in the 2003 permits are not to exceed the safe yield of a system as determined by MDEP. If the firm yield of a system is established as the maximum authorized withdrawal rate, then withdrawals, would underutilize water available above the streamflow thresholds during most years. As a consequence, withdrawals from the Ipswich River Basin during most years would satisfy less of a community's watersupply needs than could be sustained by limiting withdrawals to streamflow thresholds only.

Water demands above the firm-yield rate have a greater risk of failure (inability to meet the prespecified demand rate), however. Unlike previous simulations, which determined yields that could be meet under various conditions, but depleted storage (although this is no guarantee of being failure free), simulations in this part of the study were designed to cause near failures at progressively less severe droughts to evaluate the tradeoff between the system yield and risk. In these simulations, storage was depleted but demands were meet at the specified rate and are referred to herein as the second, third, fourth, fifth and sixth failure of the system. The yield of each supply system was calculated by incrementally changing the average 19982000 demands through the MFACT multiplier in the EXT SOURCE block, as was done in the firm yield analysis, until the reservoir storage was nearly depleted at successive failures. The yield reported was the withdrawal rate (made by modifying MFACT by two-significant digits to the right of the decimal) that maintained the least storage in the reservoir, but still satisfied demands at the near specified failure. In two cases, Peabody at the second failure and Salem-Beverly at the third failure, MFACT was increased by the smallest incremental change tested, but it also lead to an additional failure as explained below. The first failure is the firm yield of the system simulated previously (FY-IPR1); subsequent failures are identified by the uci file name and IDSCEN attribute of FYIPR4a through FY-IPR4e, respectively. Failures were separated by a period of at least partial recovery.

The yield of each system increased as the reservoir failure increased despite the fact that during the failure storage was depleted, and thus, increased the volume of the specified demand that went unsatisfied. Withdrawals that cause successive failures increase the time during which the reservoir storage is depleted in previous failures, and thereby increase the volume of the prespecified withdrawal that goes unsatisfied. The risk of failure was calculated as the number of days a reservoir is in a failed state (depleted storage) divided by the total number of days in the simulation period (12,783 days). For this analysis, a failed state was defined as any day the average daily reservoir volume was equal to zero. The yield at each successive failure and information related to the system performance at each failure is summarized in table 8 .

The Lynn system could meet average 1998-2000 demands before the fourth failure, therefore, yields and reservoir performance are reported for demands up to the third failure and for the average 1998-2000 demands (table 8 and fig. 21). Average daily reservoir storage was depleted from about 1 to 2.6 percent of the time at the withdrawal rates that caused the second failure and average 1998-2000 demands, respectively (fig. $21 B$ ). The reservoir storage was depleted for 113 to 336 days (table 8 ) between these demand rates (9.43 and 10.6 $\mathrm{Mgal} / \mathrm{d}$, respectively) during the simulation period. The reservoir refills in most years at each of the simulated demand rates except for periods following below normal precipitation. The reservoir storage-duration curves indicate that storage is above 50 percent capacity 90 percent of the time for each of the demand rates simulated. 
Table 8. Summary of yield and reservoir performance at successive failures simulated with the Hydrologic Simulation ProgramFORTRAN (HSPF) for the Lynn, Peabody, and Salem-Beverly water-supply systems, Massachusetts, 1961-95.

[Mgal, million gallons; Mgal/d, million gallons per day]

\begin{tabular}{|c|c|c|c|c|c|c|c|c|c|}
\hline \multirow[b]{2}{*}{$\begin{array}{l}\text { Failure } \\
\text { number }\end{array}$} & \multirow[b]{2}{*}{$\begin{array}{c}\text { Yield } \\
\text { (Mgal/d) }\end{array}$} & \multirow[b]{2}{*}{$\begin{array}{l}\text { Percent } \\
\text { increase }\end{array}$} & \multirow[b]{2}{*}{$\begin{array}{l}\text { Date of } \\
\text { failure }\end{array}$} & \multirow[b]{2}{*}{$\begin{array}{c}\text { Storage } \\
\text { remaining } \\
\text { (Mgal) }\end{array}$} & \multicolumn{2}{|c|}{ Number of days failed } & \multicolumn{3}{|c|}{ Volume deficit } \\
\hline & & & & & Total & $\begin{array}{c}\text { Maximum } \\
\text { consecutive } \\
\text { days }\end{array}$ & $\begin{array}{c}\text { Total } \\
\text { (Mgal) }\end{array}$ & $\begin{array}{c}\text { Maximum } \\
\text { consecutive } \\
\text { (Mgal) }\end{array}$ & $\begin{array}{c}\text { Percent } \\
\text { chance of } \\
\text { failure }\end{array}$ \\
\hline \multicolumn{10}{|c|}{ Lynn } \\
\hline 1 & 8.59 & 0 & $1-13-1967$ & 77 & 0 & 0 & 0 & 0 & 0 \\
\hline$* 4$ & 10.60 & 5.0 & $2-21-1981$ & 279 & 336 & 183 & 3,562 & 1,940 & 2.6 \\
\hline \multicolumn{10}{|c|}{ Peabody } \\
\hline 1 & 3.24 & 0 & $1-09-1967$ & 29 & 0 & 0 & 0 & 0 & 0 \\
\hline 2 & 3.30 & 1.8 & 11-16-1981 & $0^{\mathrm{a}}$ & 12 & 10 & 40 & 33 & .1 \\
\hline 6 & 4.60 & 12.8 & 3-14-1980 & 10 & 631 & 146 & 2,904 & 672 & 4.9 \\
\hline \multicolumn{10}{|c|}{ Salem-Beverly } \\
\hline 1 & 8.38 & 0 & $2-02-1967$ & 108 & 0 & 0 & 0 & 0 & 0 \\
\hline 2 & 9.29 & 9.8 & $1-23-1966$ & 28 & 144 & 144 & 1,338 & 1,338 & 1.1 \\
\hline 3 & 9.39 & 1.0 & 11-16-1981 & $0^{\mathrm{a}}$ & 158 & 151 & 1,484 & 1,418 & 1.2 \\
\hline$* 4$ & 10.10 & 7.0 & 2-20-1981 & 285 & 311 & 165 & 3,141 & 1,667 & 2.4 \\
\hline
\end{tabular}

* Withdrawal rate equal to the average 1998-2000 demand did not result in a fourth failure.

a Smallest incremental change in the fractional 1998-2000 demand tested resulted in depletion of reservoir storage for a short period of time (November 15-16, 1981 for Peabody and November 14-16, 1981 for Salem-Beverly) rather than a near depletion of storage at the specified failure.

The yield of the Peabody system increased from $3.24 \mathrm{Mgal} / \mathrm{d}$ at the first failure (firm yield) to $4.60 \mathrm{Mgal} / \mathrm{d}$ at the sixth failure or an increase from 55 to 78 percent of the average 1998-2000 demands. Note, the demand rate that caused the second failure in the Peabody system represents a change in the average 1998-2000 demand from 0.55 at the firm yield rate to 0.56 , but this also caused storage to be depleted for 10 consecutive days in January 1967 and two consecutive days in November 1981. Demand rates that cause the sixth failure deplete storage in parts of 6 years-1965-67, 1980-81, and 1985 (fig. 22A), but this demand rate still requires that 22 percent (about 1.3 Mgal/d) of the average 1998-2000 Peabody demand be met from other sources. Average daily reservoir storage was depleted less than 1 percent of the time at the demand rate that caused the second failure to about 5 percent of the time at the demand rate that caused the sixth failure (fig. 22B). The reservoir storage was depleted for 12 to 631 days (table 8) between demand rates that cause the second and sixth failures (3.30 and $4.60 \mathrm{Mgal} / \mathrm{d}$, respectively) during the simulation period. The reservoir refills in most years at even the $4.60 \mathrm{Mgal} / \mathrm{d}$ demand rate.
The yield of the Salem-Beverly system, like the Lynn system, could meet average 1998-2000 demands before the fourth failure and, therefore, yields and reservoir performance are reported for demands up to the third failure and for the average 1998-2000 demand rate (table 8 and fig. 23). System yields increased from $8.38 \mathrm{Mgal} / \mathrm{d}$ at the first failure (firm yield) to $9.39 \mathrm{Mgal} / \mathrm{d}$ at the third failure or an increase from 83 to 93 percent of the average 1998-2000 demands. Note the yield increased from 92 to 93 percent of the average 1998-2000 demand from the second to the third failure, but the third failure demand also depleted storage for 3 days in November 1981. Average daily reservoir storage was depleted between about 1.1 and 2.4 percent of the time at the demand rate that caused successive failures (fig. 23B). The reservoir storage was depleted for 144 to 311 days (table 8) between demand rates that cause the second failure $(9.29 \mathrm{Mgal} / \mathrm{d})$ and the average 1998-2000 demands. The reservoir refills in most years even at the average 1998-2000 demand rate. 


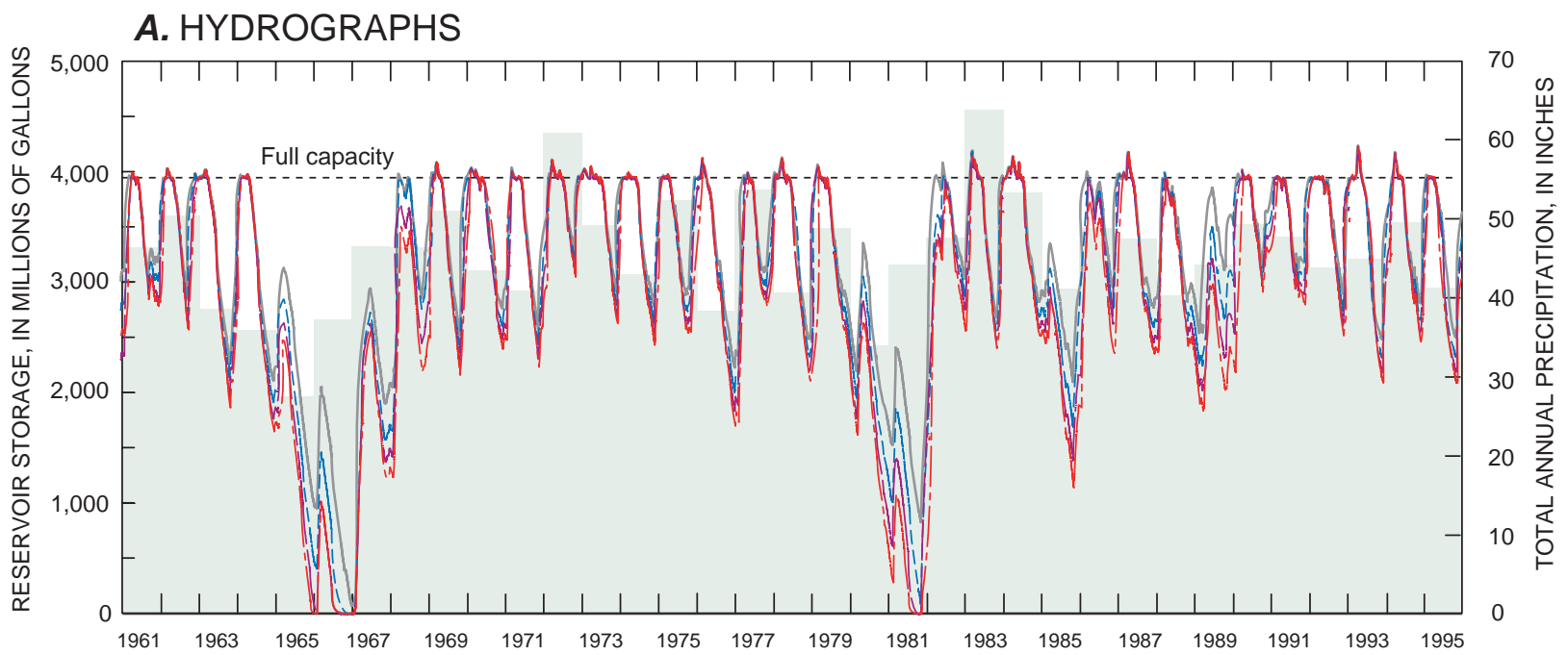

\section{B. DURATION CURVES}

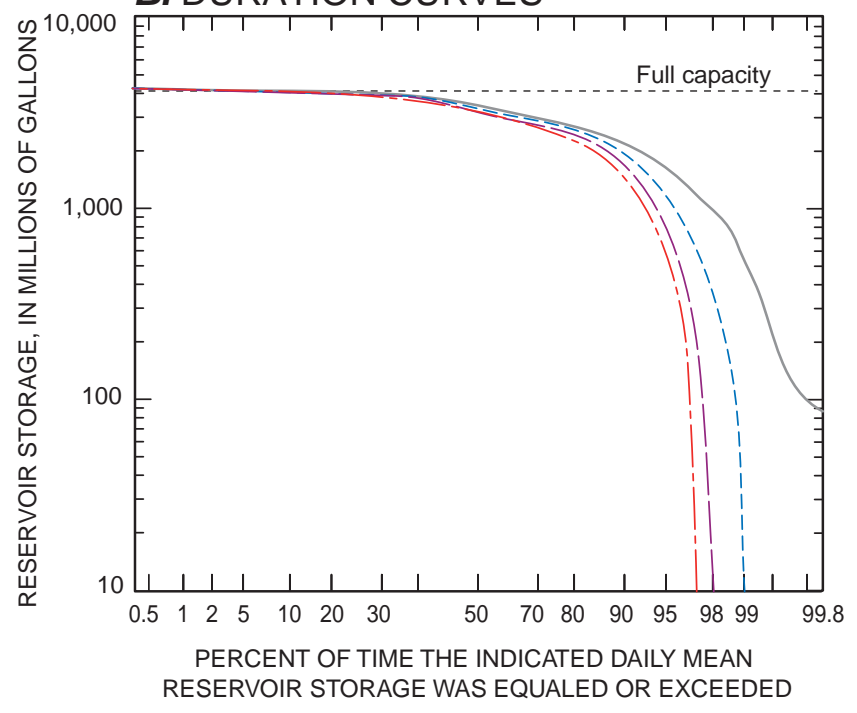

EXPLANATION

TOTAL ANNUAL PRECIPITATION

AVERAGE WITHDRAWAL RATE IN MILLION GALLONS PER DAY (Mgal/d)

IPR-1-Firm yield $(8.59 \mathrm{Mgal} / \mathrm{d})$

IPR-4A-Second failure $(9.43 \mathrm{Mgal} / \mathrm{d})$

- IPR-4B-Third failure $(10.07 \mathrm{Mgal} / \mathrm{d})$

- - - IPR-4C-Average 1998-2000 demand $(10.6 \mathrm{Mgal} / \mathrm{d})$

Figure 21. Daily mean reservoir storage $A$, hydrographs and $B$, duration curves simulated at withdrawal rates that cause successive failures under the 2003 permitted withdrawals, Lynn water-supply system, Massachusetts, 1961-95. 
A. HYDROGRAPHS

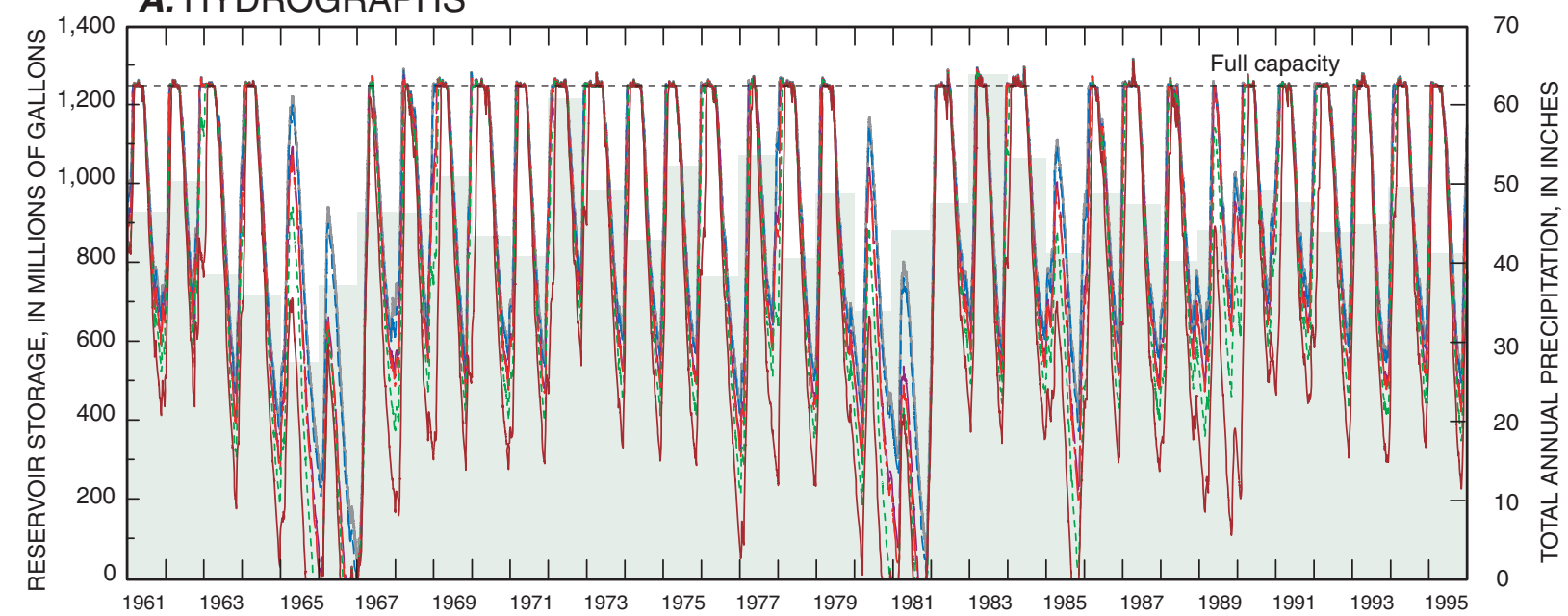

B. DURATION CURVES

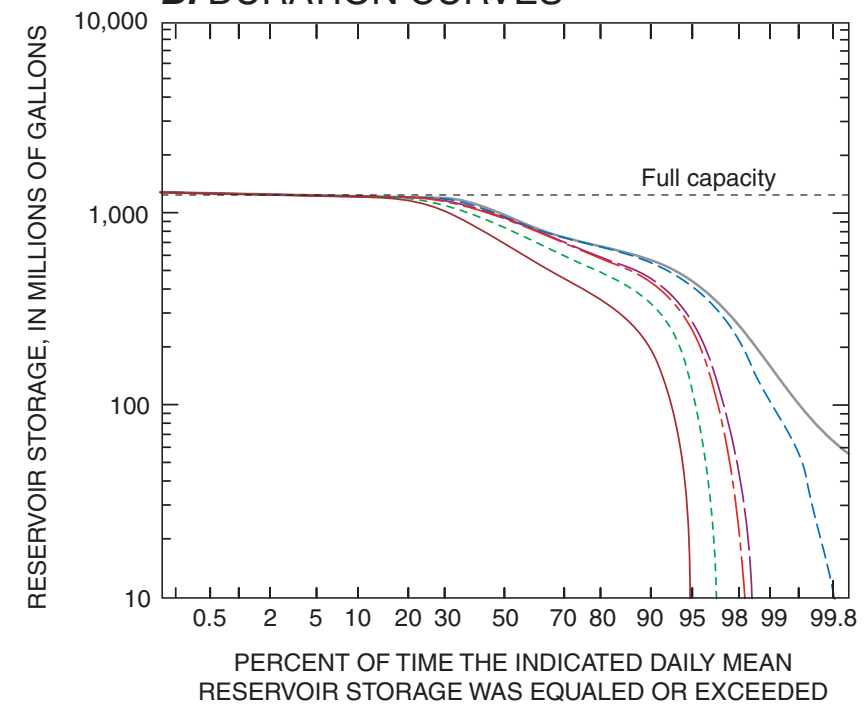

\section{EXPLANATION}

TOTAL ANNUAL PRECIPITATION AVERAGE WITHDRAWAL RATE IN MILLION GALLONS PER DAY (Mgal/d) IPR-1-Firm yield
(3.24 Mgal/d)

IPR-4A-Second failure (3.30 Mgal/d)

- IPR-4B-Third failure (3.60 Mgal/d)

- - - IPR-4C-Fourth failure (3.66 Mgal/d)

IPR-4D-Fifth failure $(4.01 \mathrm{Mgal} / \mathrm{d})$

IPR-4E-Sixth failure (4.60 Mgal/d)

Figure 22. Daily mean reservoir storage $A$, hydrographs and $B$, duration curves simulated at withdrawal rates that cause successive failures under the 2003 permitted withdrawals, Peabody water-supply system, Massachusetts, 1961-95. 


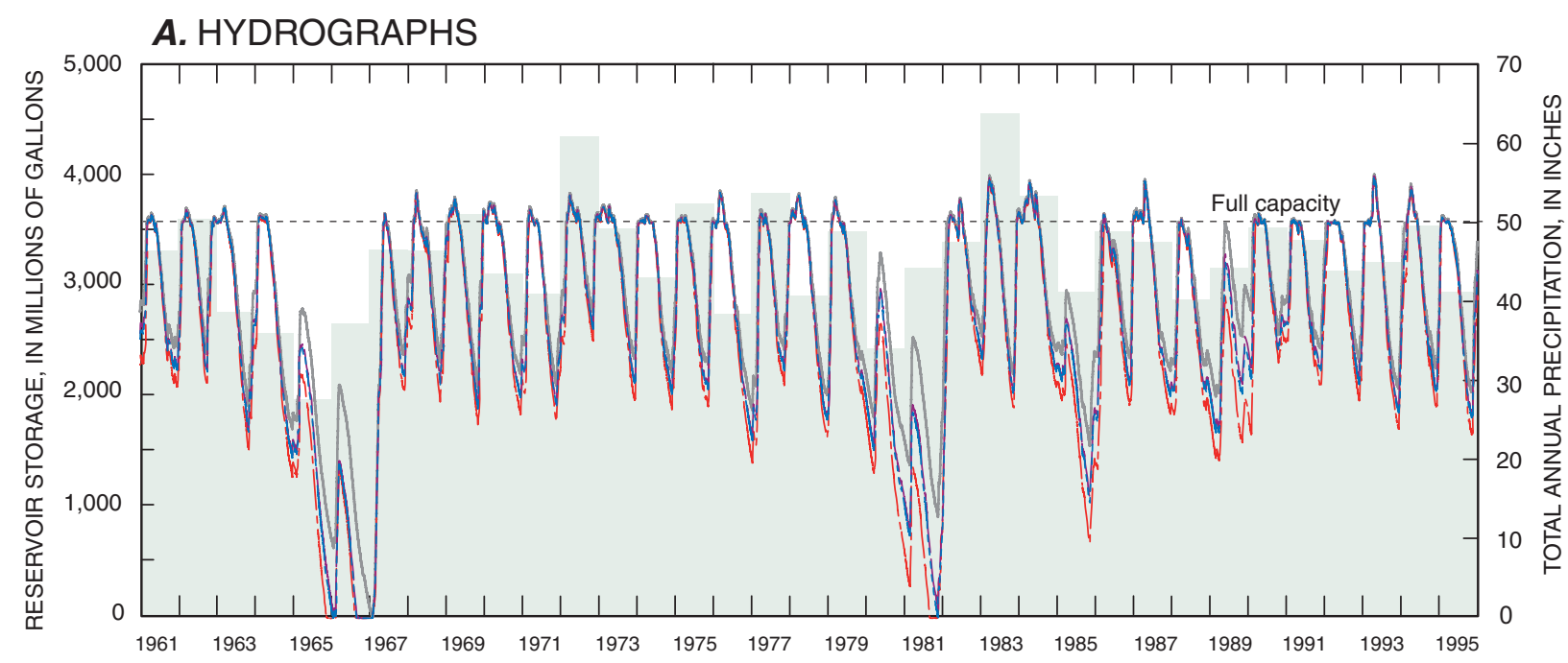

\section{B. DURATION CURVES}

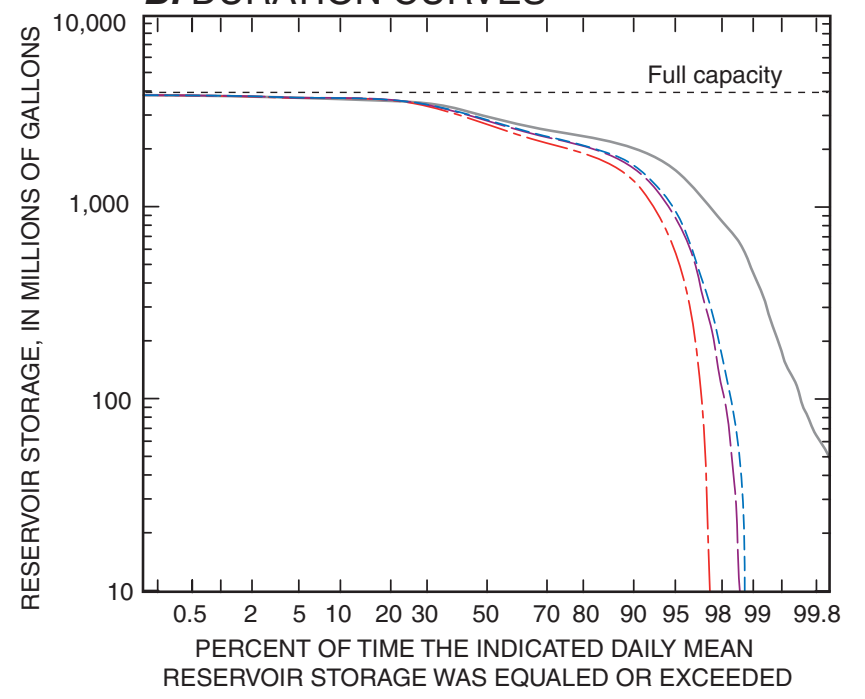

\section{EXPLANATION}

\section{TOTAL ANNUAL PRECIPITATION}

AVERAGE WITHDRAWAL RATE IN MILLION GALLONS PER DAY (Mgal/d)

IPR-1-Firm yield

$(8.38 \mathrm{Mgal} / \mathrm{d})$

IPR-4A-Second failure

$(9.29 \mathrm{Mgal} / \mathrm{d})$

- IPR-4B-Third failure $(9.39 \mathrm{Mgal} / \mathrm{d})$

-- Average 1998-2000 withdrawals $(10.10 \mathrm{Mgal} / \mathrm{d})$

Figure 23. Daily mean reservoir storage $A$, hydrographs and $B$, duration curves simulated at withdrawal rates that cause successive failures under the 2003 permitted withdrawals, Salem-Beverly water-supply system, Massachusetts, 1961-95. 


\section{Discussion of Reservoir Performance}

Indices of reliability, resilience, and vulnerability have been developed to characterize reservoir performance (Hashimoto and others, 1982). Reliability measures the probability that a reservoir will deliver its stated yield without failure, resilience measures how quickly a reservoir can recover from a failure, and vulnerability measures the severity of a failure. These measures are important considerations in reservoir management, but the indices proposed by Hashimoto and others (1982) generally do not apply to this study because simulations were made to determine the yield of a system that prevents failure. Nevertheless, the concepts of reliability, resilience, and vulnerability are valuable and deserve attention.

During most years, simulations of firm-yield withdrawal rates (FY-IPR1 and FY-IPR2) indicate that storage generally refills from year to year. During several periods, withdrawals at the firm-yield rate caused storage to be drawn down over 2 to 5 years; the most substantial drawdown was during the mid1960s when the systems nearly failed (figs. 5, 10, and 15). The Lynn system also took 2 years to recover after its near-failure during this period. These results indicate that these systems are still subject to over-year behaviors (Vogel and others, 1999); and given the possibility of more severe drought conditions, bootstrap or stochastic simulations are required to understand the reliability of these systems to supply the calculated firm yield.

The reliability of each system was calculated from simulations of withdrawal rates that result in one or more failures, as previously described. The tradeoff between yield and the risk of failure (inverse of the reliability) indicates that the yield of each system can increase substantially as previously described and summarized in figure 24 if a greater possibility of failure can be tolerated. Tolerating failure requires the systems fail safely, that is, they are designed to minimize the effects of failure rather than trying to make the systems fully fail-safe (failure free), a concept discussed by Hashimoto and others (1982). Uncertainties in model performance, simplification of reservoir systems and their management, and the possibility of droughts of greater severity underscore that the calculated firm yield of each system cannot be considered a withdrawal rate that is failsafe; hence, the ability of a system to fail safely is an important consideration in the planning and management of water-supply systems. One method of assuring safe failure is the ability to rely on other sources of water to meet demands.

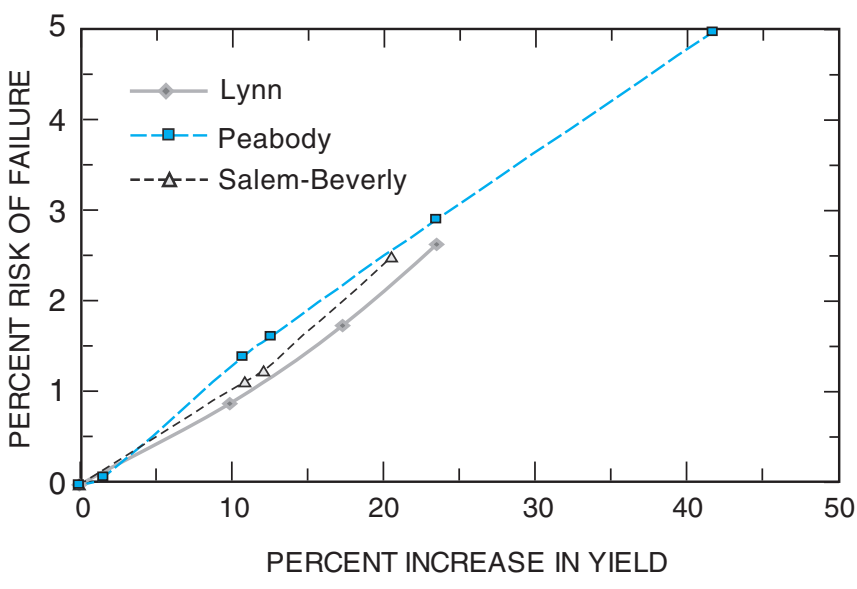

Figure 24. Relation of yield and risk of failure simulated under 2003 permitted withdrawals for the Lynn, Peabody, and SalemBeverly water-supply systems, Massachusetts, 1961-95.

Resilience and vulnerability were measured for demand rates that resulted in one or more failures (periods of depleted storage and unsatisfied demand). Resilience, the quickness of a reservoir to recover from a failure, was measured as the maximum number of consecutive days that storage was depleted during a failure. Vulnerability, the maximum severity of a failure, was measured as the volume of the unsatisfied demand at the specified withdrawal rate (stated yield) during the longest continuous failure period.

Demands from the Lynn system that resulted in a second failure $(9.43 \mathrm{Mgal} / \mathrm{d})$ caused the first failure to last for 113 consecutive days and an unsatisfied yield of 1,066 Mgal. At the demand rate that caused the third failure $(10.07 \mathrm{Mgal} / \mathrm{d})$, the first failure lasted for 172 consecutive days and resulted in an unsatisfied demand of 1,732 Mgal. At the average 1998-2000 demand rate $(10.6 \mathrm{Mgal} / \mathrm{d})$ the maximum number of consecutive days Lynn's system failed (183 days) and the unsatisfied yield (1,940 Mgal) during that time increased only slightly when compared to the first two failures (table 8).

Demands from the Peabody system that resulted in a second failure caused the first failure to last for only 10 consecutive days and an unsatisfied yield of $33 \mathrm{Mgal}$. This represents an increase from the average 1998-2000 demand of 0.55 at the firm yield rate to 0.56 , but it should be noted that the 
second failure also caused the Peabody system to fail for 2 days in November 1981. At the demand rate that caused a third failure (3.60 Mgal/d), the first failure lasted for 99 consecutive days and resulted in an unsatisfied yield of $356 \mathrm{Mgal}$. Demands that caused the next three failures $(3.66,4.01$, and $4.60 \mathrm{Mgal} / \mathrm{d}$, respectively) resulted in relatively small increases in the maximum number of consecutive days the reservoir failed and the unsatisfied yield during that period when compared to the first two failures (table 8).

Demands from the Salem-Beverly system that resulted in a second failure caused the first failure to last for 144 consecutive days and an unsatisfied yield of 1,338 Mgal. Subsequent failures of the Salem-Beverly system resulted in small increases in the number of consecutive days the reservoir failed and the unsatisfied yield during that time (table 8). The demand increased from the average 1998-2000 rate from 0.92 at the second failure to 0.93 at the third failure, again it should be noted that the third failure also caused the Salem-Beverly system to fail for 3 days in November 1981.

These results above indicate that the resilience and vulnerability of the supply systems generally do not change appreciably after the first failure for the Lynn and SalemBeverly systems and after the second failure for the Peabody system. During the longest consecutive period of failure, the quantity of water required to meet the specified yield for the highest demand rates simulated was about 1,940 Mgal for the Lynn system, $672 \mathrm{Mgal}$ for the Peabody system, and 1,667 Mgal for the Salem-Beverly system. These values are conservative because they do not incorporate the common management practice of progressive restrictions on water use as usable storage drops to critical levels.

The storage characteristics of each system at successive failures were examined by the variation in the average monthly reservoir storage for each month of the year over the 35-year simulation period (1961-95). To simplify comparisons, only the months of April and November are presented, which are normally the months with the highest and lowest storage, respectively. Box plots show the central tendency, spread, and symmetry of the average April and November storage for simulations under the 2003 permitted withdrawal rates that cause successive failures (fig. 25). The robustness of a system can be viewed as the tendency to be near capacity in April and retain some capacity in November. The level of storage in April determines the fitness of the system as it enters the period of the year when withdrawals are most restrictive and streamflows decrease to normal seasonal lows. The level of storage in November is indicative of the strength of the system at the end of this period.

The median average storage in April was at or near capacity for each system and each demand rate simulated. Median storage in April for each system, although mostly near capacity, was occasionally below 75 percent of capacity (outliers), but never below about 25 percent of capacity at any of the demand rates simulated. Storage in April was only below capacity for any appreciable time for Lynn system at the third and forth highest demand rate simulated and Peabody system at the highest demand rate simulated.

The average November storage pattern was generally similar to the average April storage, but at lower levels (fig. 25). In all simulations, for all systems, the average November storage was never at capacity. The median average November storage for the Lynn system ranged from about 73 percent of capacity at the firm-yield demand rate to about 63 percent of capacity at the average 1998-2000 demand rate. The lower whisker indicates that the average November storage in the Lynn system was about half capacity at the firm-yield demand rate, about 38 percent of capacity at the demand rate that caused successive failures (9.43 to $10.6 \mathrm{Mgal} / \mathrm{d}$ ).

The median average November storage for the Peabody system generally ranged from about 30 to 50 percent of capacity; the upper and lower quartiles ranged from about 23 to 57 percent of capacity, and the whiskers were within about 8 to 72 percent of capacity (fig. 25). The average November storage in the Peabody system was occasionally below 25 percent of capacity and was depleted or nearly depleted at least twice at all demand rates above the firm yield. The average November storage characteristics at the demand rate that caused the sixth failure in the Peabody system were appreciably less than indicated for lower demand rates.

The median average November storage for the SalemBeverly system generally ranged from about 56 to 67 percent of capacity; the upper and lower quartiles ranged from about 45 to 64 percent of capacity, and the whiskers were within about 40 to 72 percent of capacity. Still, the average November storage in the Salem-Beverly system was occasionally near depletion as indicated by the lower outliers (fig. 25). 


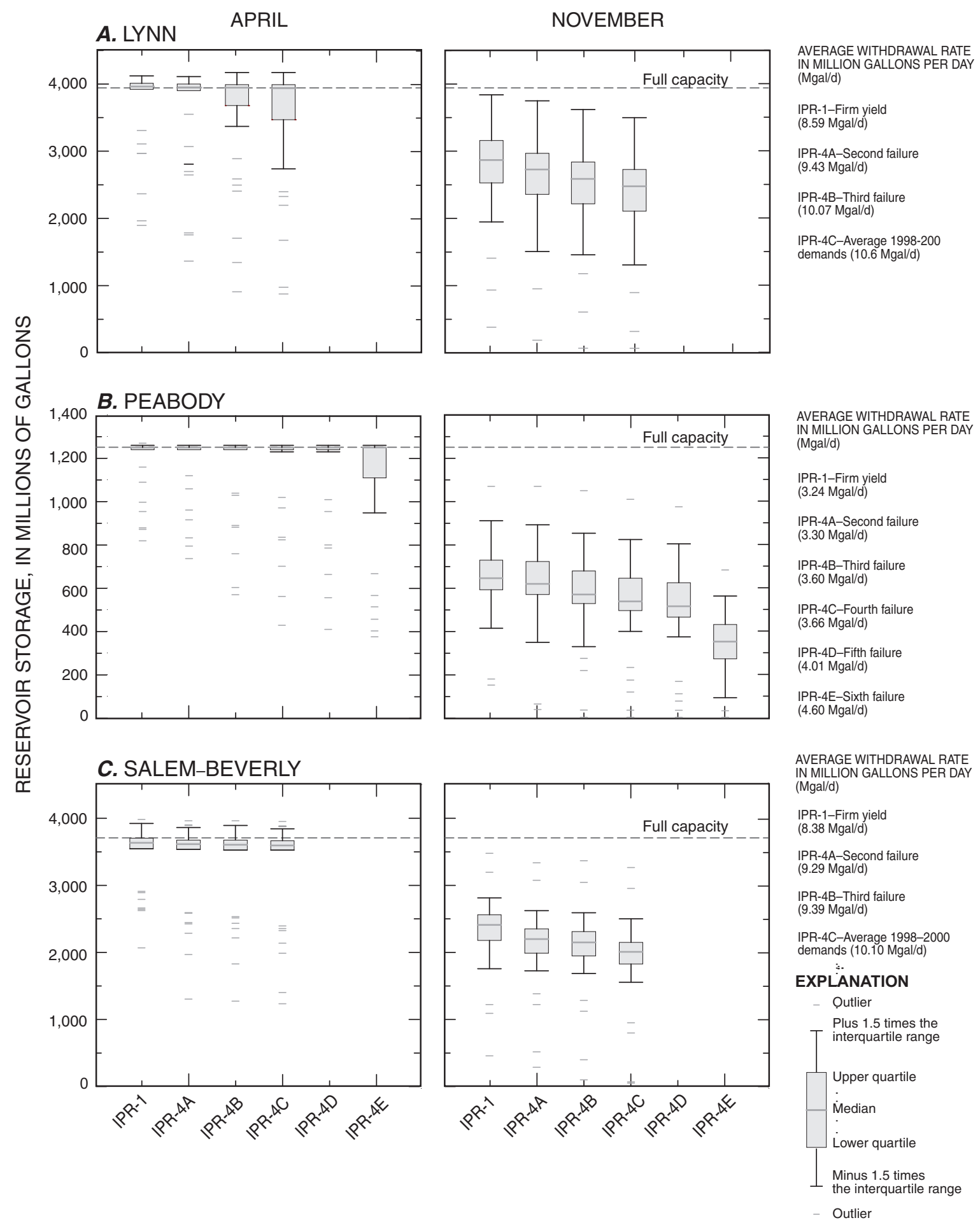

Figure 25. Simulated average monthly reservoir storage during April (normally highest) and November (normally lowest) at demand rates that cause successive failures under 2003 permitted withdrawals for the $A$, Lynn; $B$, Peabody; and C, Salem-Beverly water-supply systems, Massachusetts, 1961-95. 
Failures could be minimized, or possibly averted, if management practices such as water restrictions or relaxing withdrawal criteria, or both, could be implemented with sufficient lead time to maintain or preserve storage. Understanding the climatic conditions that caused failures could help water-resource managers determine when, under current climate conditions, strategies such as those above need to be implemented. Periods preceding failures were characterized by the antecedent precipitation in the past 60, 90, 183, 365, 730, and 1,095 days to evaluate whether these antecedent conditions could provide useful management information.

Although antecedent precipitation was generally low in all periods leading to a failure, the first failures were preceded by relatively long periods of low precipitation, and later failures tended to be preceded by relatively short intense droughts (fig. 26). Precipitation preceding the first failure, February 1967, was among the lowest for 730 and 1,095 consecutive day periods, but was only near the lower quartile for periods less than 183 consecutive days. Precipitation preceding the February 1966 failure (second failure for the Salem-Beverly system and the third failure for the Lynn and Peabody systems) was among the lowest for 183 consecutive days or more and set the conditions that led to the initial failure in the following year. Precipitation preceding the November 1981 failure (second failure for Lynn and Peabody and the third failure for SalemBeverly) was below the lower quartile for antecedent periods of 183 days or more, but precipitation preceding this failure was greater than the precipitation preceding some other failures, especially for short antecedent periods.

Supply systems are at greatest risk of failure from persistent droughts (those lasting more than 1 year), but short-term droughts also present risks, particularly when precipitation is below normal in the fall and winter when storage is low in the systems. The later failures were often triggered when the systems were unable to recover during the preceding spring and the storage was diminished because of high summer demands, low seasonal streamflow, and withdrawals restricted to relatively high streamflow criteria. The timing of failures in the fall and winter are determined by the storage conditions in the preceding spring and the magnitude of the precipitation deficit (with respect to both length of time and volume). The greater the storage in the spring, the more resilient the systems are to failure; as spring storage decreases, the systems become more vulnerable to short-term droughts in the fall and winter. For example, low precipitation before March 1980 caused the sixth failure of the Peabody system, but did not cause the other systems to fail. Antecedent precipitation for March 1980 was the lowest for a 60-day period and among the lowest for 90 - and 183-day periods; storage in the preceding spring was at capacity; therefore, the system was less vulnerable to failure. Antecedent precipitation leading to the fourth failure for each system (February 1981) was low, but not as low as in March 1980; however, the reservoirs failed sooner in February 1981 because storage in the preceding April averaged 59 percent of capacity in the Lynn and Peabody systems and 42 percent of capacity of the Salem-Beverly system.

Knowledge of the expected recurrence of drought conditions that can lead to failures could help water managers evaluate risks related to these failures. The expected recurrences of minimum antecedent precipitation in the past $90,183,365,730$, and 1,095 days were determined by log-Pearson Type III analysis using SWSTAT (Lumb and others, 1994). Return probabilities were computed from annual time series of the lowest total precipitation for these antecedent conditions for the 1961-95 period.

The expected return period of antecedent conditions that lead to successive failures varies widely. The antecedent condition that led to the first failure (February 1967) has an expected recurrence of about 50 years on the basis of total precipitation over a 3-year period, but short-term drought conditions preceding this failure are likely to occur nearly every year (fig. 27). This result underscores the importance of longterm droughts that affect the storage conditions, which cause the systems to fail during relatively mild short-term droughts.

Antecedent conditions that led to subsequent failures do not show a consistent pattern. The November 1981 failure, which triggered the second failure of the Lynn and Peabody systems, had more antecedent precipitation over all periods than the February 1966 failure, which triggered the third failure in each system. These findings underscore the importance of how spring storage conditions can affect reservoir performance much later in the year. Thus, climatic conditions alone are not good indicators of potential failure. 

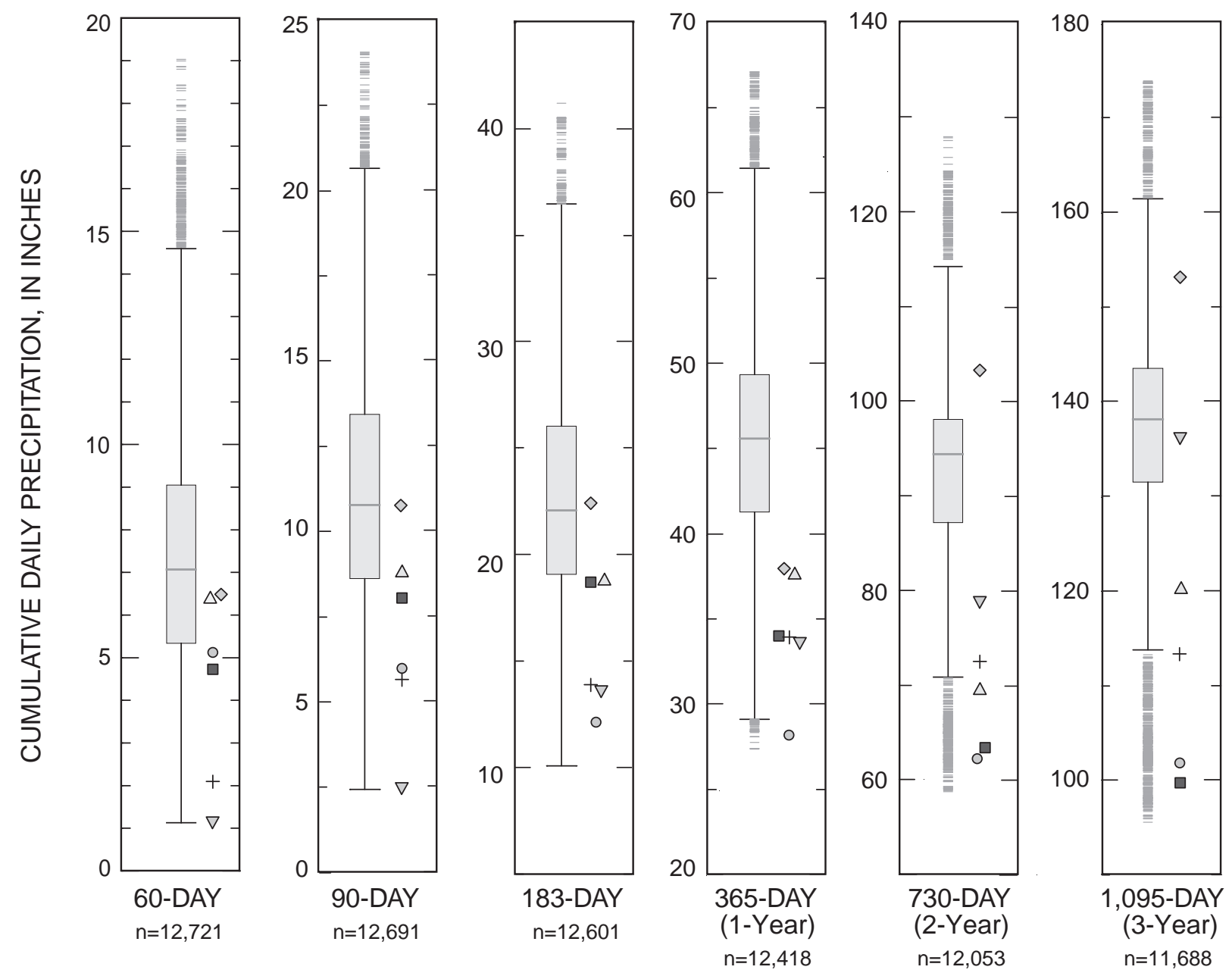

EXPLANATION

\begin{tabular}{lcccc} 
& Failure & Lynn & Peabody & Salem-Beverly \\
\cline { 2 - 5 } & 1 & $\square$ & $\square$ & $\square$ \\
$\square$ February 1967 & 2 & $\Delta$ & $\Delta$ & $\circ$ \\
$\Delta$ November 1981 & 3 & $\circ$ & $\circ$ & $\Delta$ \\
$\circ$ February 1966 & 4 & + & + & + \\
+ February 1981 & 5 & ND & $\diamond$ & ND \\
$\diamond$ November 1985 & 6 & ND & $\nabla$ & ND \\
$\nabla$ March 1980 & & & & \\
ND Not determined & & & & \\
n Number of observations & & &
\end{tabular}

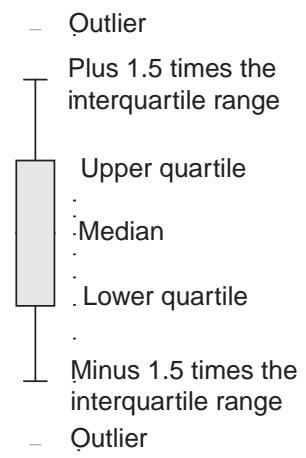

Figure 26. Characteristics of total precipitation in the past $60,90,183,365,730$, and 1,095 days and antecedent conditions that led to simulated successive failures under the 2003 permitted withdrawals for the Lynn, Peabody, and Salem-Beverly water-supply systems, Massachusetts, 1961-95. 


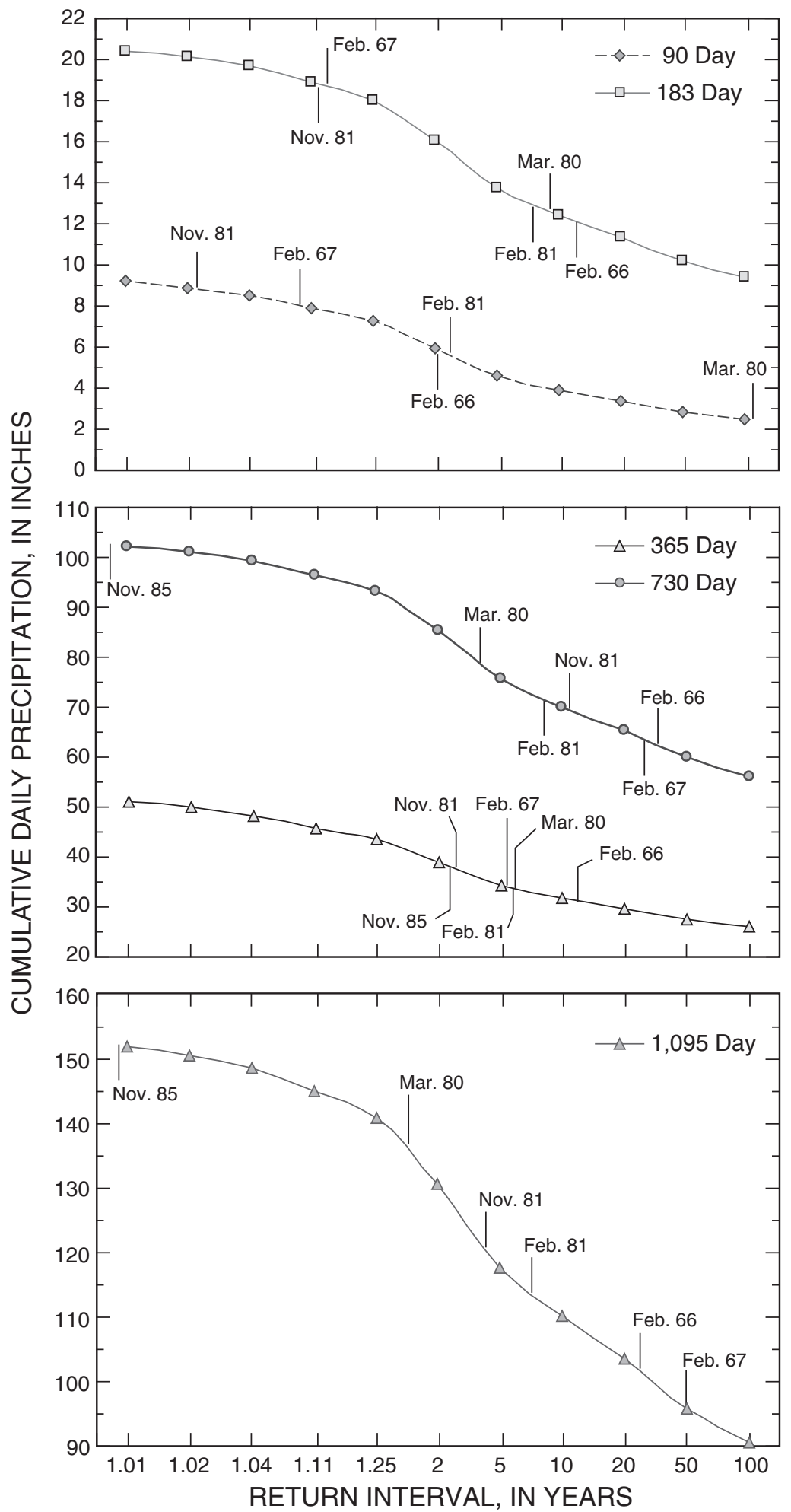

FAILURE DATES

\begin{tabular}{cccc} 
Failure & Lynn & Peabody & $\begin{array}{c}\text { Salem- } \\
\text { Beverly }\end{array}$ \\
\hline 1 & Feb. 67 & Feb. 67 & Feb. 67 \\
2 & Nov.81 & Nov. 81 & Feb. 66 \\
3 & Feb. 66 & Feb. 66 & Nov. 81 \\
4 & Feb. 81 & Feb. 81 & Feb. 81 \\
5 & - & Nov. 85 & - \\
6 & - & Mar. 80 & -
\end{tabular}

- Not determined

Figure 27. Expected recurrence of minimum 90-, 183-, 365-, 730-, and 1,095-day precipitation and the expected recurrence of droughts on the basis of these antecedent conditions that led to simulated successive failures under the 2003 permitted withdrawals for the Lynn, Peabody, and Salem-Beverly water-supply systems, Massachusetts, 1961-95. 


\section{Summary}

The sustainability of a water-supply system is a function of its storage capacity and the rate of total inflows and outflows to the system. These factors determine the firm yield or safe yield of a supply system, which is the maximum demand rate that can be sustained during droughts. The Commonwealth of Massachusetts requires water suppliers to furnish firm-yield information about their system to ensure that communities can meet current and future water-supply demands. The yields of water-supply systems that obtain water from the Ipswich River Basin, Massachusetts, are not easy to determine because the inflows to these systems are complicated by the regulations that restrict withdrawals by the time of year, minimum streamflow thresholds, and capacity to pump water from the river. The effects of the 2003 withdrawal permits and management alternatives on yields of three surface-water-supply systems that obtain water from the Ipswich River Basin (the Lynn, Peabody, and Salem-Beverly water-supply systems) were investigated by the U.S. Geological Survey (USGS) in cooperation with the Massachusetts Department of Environmental Protection (MDEP) in 2003.

The Hydrologic Simulation Program-FORTRAN (HSPF) model previously developed by the USGS for the Ipswich River Basin was modified to evaluate the effects of withdrawal restrictions on reservoir storage and firm yields of the Lynn, Peabody, and Salem-Beverly water-supply systems. The MDEP 2003 withdrawal permits were established to balance public-water supply needs and environmental interest. These permits restrict withdrawals to November 1 and May 31 when the river flow is above a minimum threshold of $1.0 \mathrm{ft}^{3} / \mathrm{s} / \mathrm{mi}^{2}$, to high flows between June 1 and October 31, and to a maximum annual volume. The special-actions feature of the HSPF model previously developed to simulate inflows to these supply systems was modified to reflect these restrictions and to simulate the effects of a hypothetical low-capacity pump, alternative seasonal-flow thresholds, and yields at successive near reservoir failures (near failures that occur during less severe droughts).

The simulation results indicate that, under the 2003 permitted withdrawals, none of the systems could sustain a demand rate equal to the average 1998-2000 demands. The Lynn system, simulated at the average 1998-2000 demand rate (10.6 Mgal/d), failed in 4 of 35 years; the annual storage averaged about 73 percent of capacity. Storage in the Lynn system was depleted about 3 percent of the time, and storage was less than 25 percent of capacity about 8 percent of the time at the $10.6 \mathrm{Mgal} / \mathrm{d}$ demand rate. The Peabody system simulated at the average 1998-2000 demand rate (5.9 Mgal/d) failed during part of all but one of 35 years; annual storage averaged about 35 percent of capacity. Storage in the Peabody system was depleted about 25 percent of the time, and storage was less than 25 percent of capacity about 50 percent of the time at the $5.9 \mathrm{Mgal} / \mathrm{d}$ demand rate. The Salem-Beverly system, simulated at the average 1998-2000 demand rate (10.1 Mgal/d), failed in 4 of 35 years; the annual storage averaged about 73 percent of capacity. Storage in the Salem-Beverly system was depleted about 3 percent of the time, and storage was less than 25 percent of capacity about 7 percent of the time at the $10.1 \mathrm{Mgal} / \mathrm{d}$ demand rate.

The firm yields calculated with the 2003 permitted withdrawals were $8.59 \mathrm{Mgal} / \mathrm{d}$ for the Lynn system, 3.24 Mgal/d for the Peabody system, and $8.38 \mathrm{Mgal} / \mathrm{d}$ for the Salem-Beverly system; these yields are 19,45 , and 17 percent less than the average 1998-2000 demands, respectively. Simulations were made with the same withdrawal restrictions and a hypothetical low-capacity pump for each system (5, 2, and $10 \mathrm{Mgal} / \mathrm{d}$ pump for the Lynn, Peabody, and Salem-Beverly systems, respectively). Simulation results indicate that the firm yield increased by $0.31 \mathrm{Mgal} / \mathrm{d}$ (to $8.90 \mathrm{Mgal} / \mathrm{d}$ for the Lynn system) and by $0.41 \mathrm{Mgal} / \mathrm{d}$ (to $8.79 \mathrm{Mgal} / \mathrm{d}$ for the Salem-Beverly system) relative to the simulation without the low-capacity pump. The firm yield of the Peabody system decreased by $0.17 \mathrm{Mgal} / \mathrm{d}$ (to $3.07 \mathrm{Mgal} / \mathrm{d}$ ) relative to the simulation without the low-capacity pump. The slight decrease in firm yield of the Peabody system is attributed to additional water being captured by the Lynn system, which was also simulated with a hypothetical lowcapacity pump.

Achieving a balance between water supply and environmental concerns requires an understanding of the tradeoff between yield and withdrawal restrictions that maintain streamflow. Thus, seasonal streamflow thresholds for November through February (fall-winter) and March through May (spring) were independently increased and decreased in 20percent increments from 0.2 to $1.8 \mathrm{ft}^{3} / \mathrm{s} / \mathrm{mi}^{2}$ ( \pm 80 percent). The June through October (summer) streamflow threshold was only decreased in 20-percent increments to -80 percent because of the relatively high flow threshold established for this period.

In all systems, the firm yield was generally about twice as sensitive to decreases than to increases in the fallwinter or spring thresholds. A 20-percent increase in the fall-winter or spring thresholds (to $1.2 \mathrm{ft}^{3} / \mathrm{s} / \mathrm{mi}^{2}$ ) decreased yields by 1 to 7 percent; an 80-percent increase in these thresholds (to $1.8 \mathrm{ft}^{3} / \mathrm{s} / \mathrm{mi}^{2}$ ) decreased yields by 3 to 18 percent. A 20percent decrease in the fall-winter and the spring thresholds $\left(0.8 \mathrm{ft}^{3} / \mathrm{s} / \mathrm{mi}^{2}\right)$ increased yields by 2 to 5 percent; an 80 -percent decrease in these thresholds $\left(0.2 \mathrm{ft}^{3} / \mathrm{s} / \mathrm{mi}^{2}\right)$ increased yields by 16 to 51 percent. In general, the firm yield was slightly less sensitive to changes in the spring threshold than to changes in the fall-winter threshold for each system. Decreases in the summer flow threshold had no effect on the firm yield of any of the systems. 
MDEP permitted withdrawals are not to exceed the safe yield that MDEP determines to be appropriate for a system. A community could meet more of its water-supply needs from the Ipswich River Basin, during most years, however, if withdrawals are restricted to only streamflow criteria. Simulations were made to evaluate the tradeoff between the system yield and risk of failure by simulating withdrawal rates that resulted in successive failures.

The yield of each system increased as it was allowed to fail more often; successive failures increased the time during which the reservoir storage was depleted, however, and thus increased the volume of the specified demand that went unsatisfied. The yield of the Lynn system increased from $8.59 \mathrm{Mgal} / \mathrm{d}$ at the firm-yield demand rate and was able to meet its average 19982000 demands $(10.60 \mathrm{Mgal} / \mathrm{d})$ before the fourth failure. Storage in the Lynn system was depleted about 3 percent of the time at the $10.60 \mathrm{Mgal} / \mathrm{d}$ demand rate. The yield of the Peabody system increased from $3.24 \mathrm{Mgal} / \mathrm{d}$ at the firm-yield demand rate to 4.60 Mgal/d at sixth failure, an increase from 55 to 78 percent of Peabody's average 1998-2000 demands. Storage in the Peabody system was depleted about 5 percent of the time at the 4.60 Mgal/d demand rate. The Salem-Beverly system met its average 1998-2000 demands before the fourth reservoir failure. The yield of the Salem-Beverly system increased from 8.38 $\mathrm{Mgal} / \mathrm{d}$ at the firm-yield demand rate to $9.39 \mathrm{Mgal} / \mathrm{d}$ at the third failure. Storage in the Salem-Beverly system was depleted about 1 percent of the time at the $9.39 \mathrm{Mgal} / \mathrm{d}$ demand rate.

Resilience, the time frame within which a reservoir recovers from a failure, and vulnerability, the maximum severity of a failure, do not appreciably change after the first failure for the Lynn and Salem-Beverly systems or after the second failure for the Peabody system. The simulated quantity of water required to meet demands during the most severe drought was about 1,900 Mgal for the Lynn system, $670 \mathrm{Mgal}$ for the Peabody system, and 1,700 Mgal for the Salem-Beverly system at the maximum demand rate simulated (10.6, 4.60, and $10.1 \mathrm{Mgal} / \mathrm{d}$, respectively). These values do not incorporate the common management practice of progressively restricting water use as storage is depleted.
The robustness of a system can be viewed as the tendency to be near capacity in April and the capacity retained in November. The level of storage in April determines the fitness of the system as it enters the period of the year when withdrawals are most restrictive and streamflows decrease to seasonal lows. The level of storage in November is indicative of the strength of the system at the end of this period. For most of the withdrawal rates tested, the average April storage, in each of the systems simulated was mostly near capacity. The average April storage was appreciably below capacity for any time only for the highest withdrawal rate simulated for the Lynn and Peabody systems. Over the range of successive failures, the November storage averaged bout 62, 42, and 58 percent of capacity for the Lynn, Peabody, and Salem-Beverly systems, respectively.

Supply systems are at greatest risk of failure from persistent droughts (those lasting more than 1 year), but shortterm droughts also present risks during the fall and winter when the supply systems are most vulnerable. The timing of these failures is determined by the storage conditions in the preceding spring and the magnitude of the precipitation deficit (with respect to both length of time and volume) in the fall-winter. The greater the storage in the spring, the more resilient the system is to failure later in the year; as spring storage decreases, systems are more vulnerable to failure from droughts in the fall and winter.

Uncertainties in model performance, the simplification of reservoir systems and their management, and the possibility of droughts of greater severity than simulated underscore that the firm yield of each system cannot be considered fail-safe. Hence, the consequences of failure are an important consideration in the planning and management of water-supply systems. Knowledge of the conditions that lead to failure could help watersupply managers determine when conservation measures or other strategies to preserve storage could be implemented with sufficient time to advert or minimize failure. Antecedent precipitation alone was not a good indicator of failure; but when used in conjunction with current reservoir conditions, it provides some insight into the likelihood of failure. 


\section{References}

Bicknell, B.R., Imhoff, J.C., Kittle, J.L., Jr., Donigian, A.S., Jr., and Johanson, R.C., 1997, Hydrological Simulation Program-FORTRAN, User's manual for version 11: Athens, GA, U.S. Environmental Protection Agency, EPA/600/R97/080, National Exposure Research Laboratory, 755 p.

Flynn, K.M., Hummel, P.R., Lumb, A.M., and Kittle, J.L., Jr., 1995, User's manual for ANNIE, version 2, a computer program for interactive hydrologic data management: U.S. Geological Survey Water-Resources Investigations Report 95-4085, $211 \mathrm{p}$.

Gomez and Sullivan Engineers, 2002, Saugus River water budget and Instream flow analysis: Weare, NH, Gomez and Sullivan Engineers, 218 p.

Hashimoto, Tuyoshi, Stedinger, J.R., and Loucks D.P., 1982, Reliability, resiliency, and vulnerability criteria for water resource system performance: Water Resources Research, v. 18 , no. 1 p. 14-20.

Hummel, P.R., Kittle, J.L., Jr., and Gray, M.H., 2001, WDMUtil-A Tool for Managing Watershed Modeling Time-Series Data, Version 2.0: U.S. Environmental Protection Agency, $157 \mathrm{p}$.

Kittle, J.L., Jr., Lumb, A.M., Hummel, P.R., Duda, P.B., and Gray, M.H., 1998, A tool for the generation and analysis of model simulations scenarios for watersheds (GenScn): U.S. Geological Survey Water-Resources Investigation Report 98-4134, $152 \mathrm{p}$.
Koutsoyiannis, Demetris, 2004, Reliability concepts in reservoir design, in The Encyclopedia of Water, Lehr, J.H., ed., 17 p., accessed February 18, 2004, at URL http://www.itia.ntua.gr/getfile/538/2/ 2004EncyclReservoirReliabPP.pdf

Lumb, A.M., Thomas, W.O., Jr., and Flynn, K.M., 1994, User's manual for SWSTAT, a computer program for interactive computation of surface-water statistics: unpublished U.S. Geological Survey report, $48 \mathrm{p}$.

Vogel, R.M., Lane, Melissa, Ravindiran, R.S., and Kirshen, Paul, 1999, Storage reservoir behavior in the United States: Journal of Water Resources Planning and Management, v. 125 , no. 5, p. 245-254.

Zarriello, P.J., and Ries, K.G., III, 2000, A precipitation runoff model for the analysis of the effects of water withdrawals on streamflow, Ipswich River Basin, Massachusetts: U.S. Geological Survey Water-Resources Investigation Report 00-4029, 99 p.

Zarriello, P.J., 2002, Simulated reservoir storage and firm yields of three surface-water supplies, Ipswich River Basin, Massachusetts: U.S. Geological Survey Water-Resources Investigation Report 02-4278, 50 p. 



\section{Appendix. Hydrologic Simulation Program- FORTRAN Special Actions Used to Simulate Withdrawals for Water-Supply Systems}





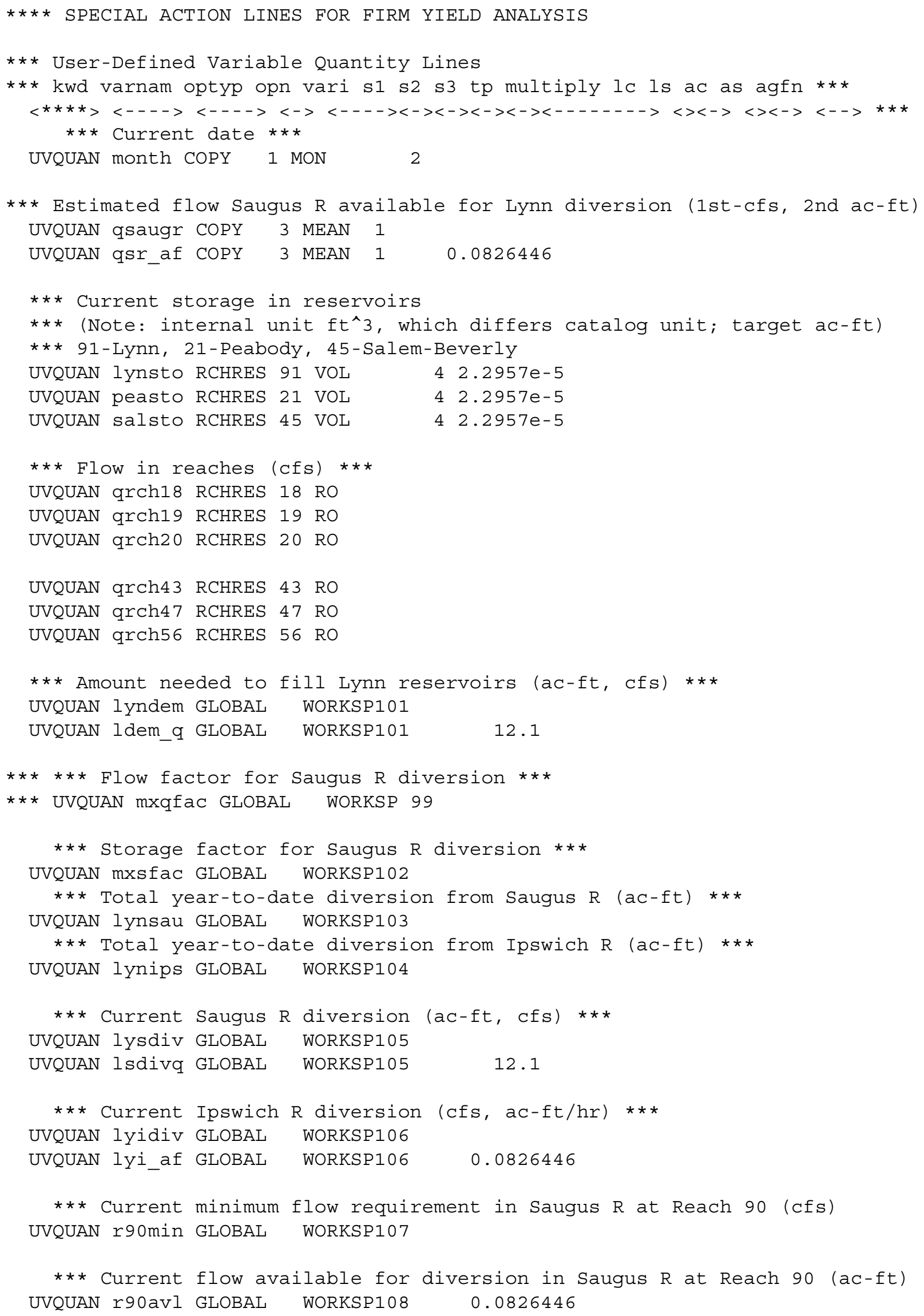




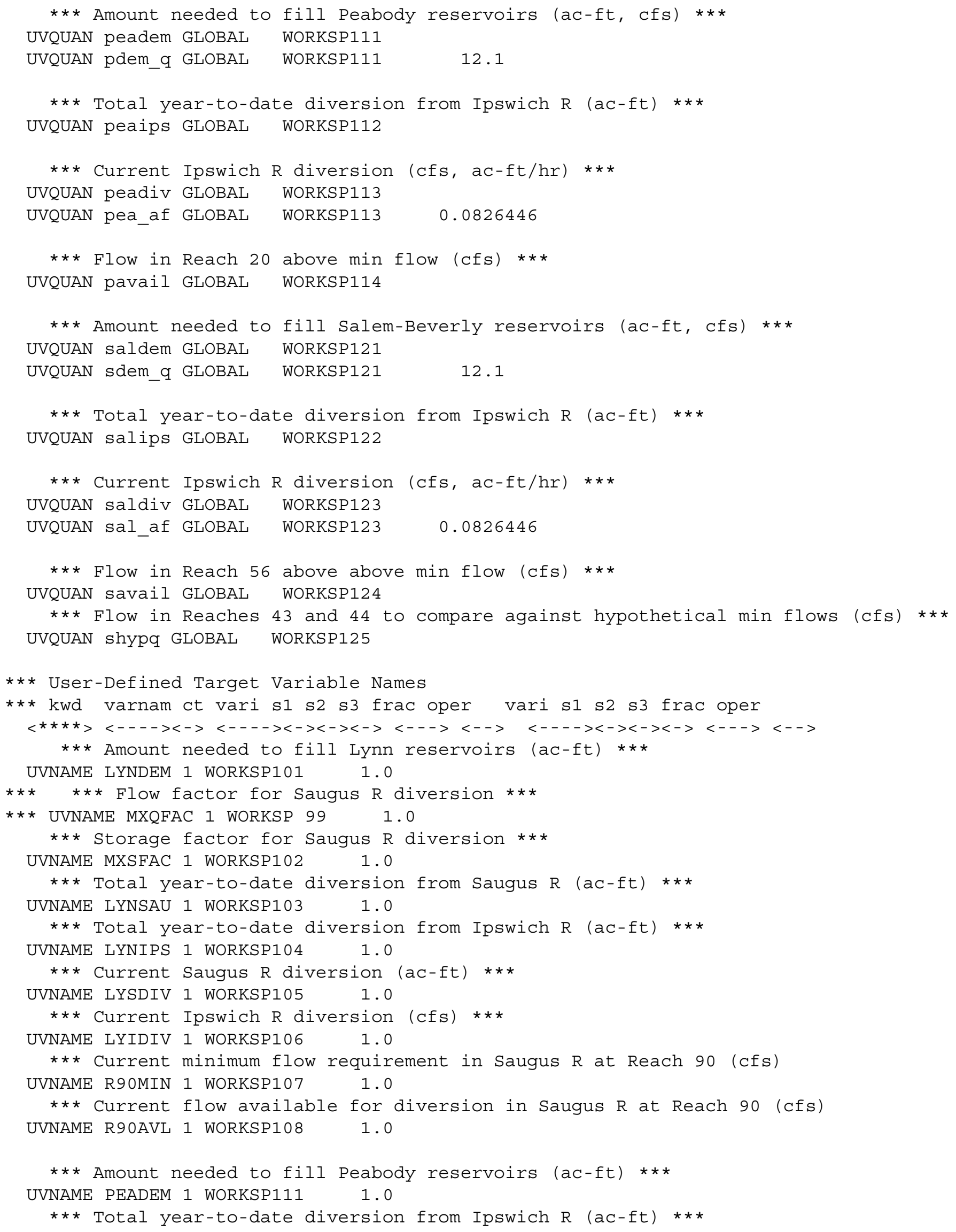




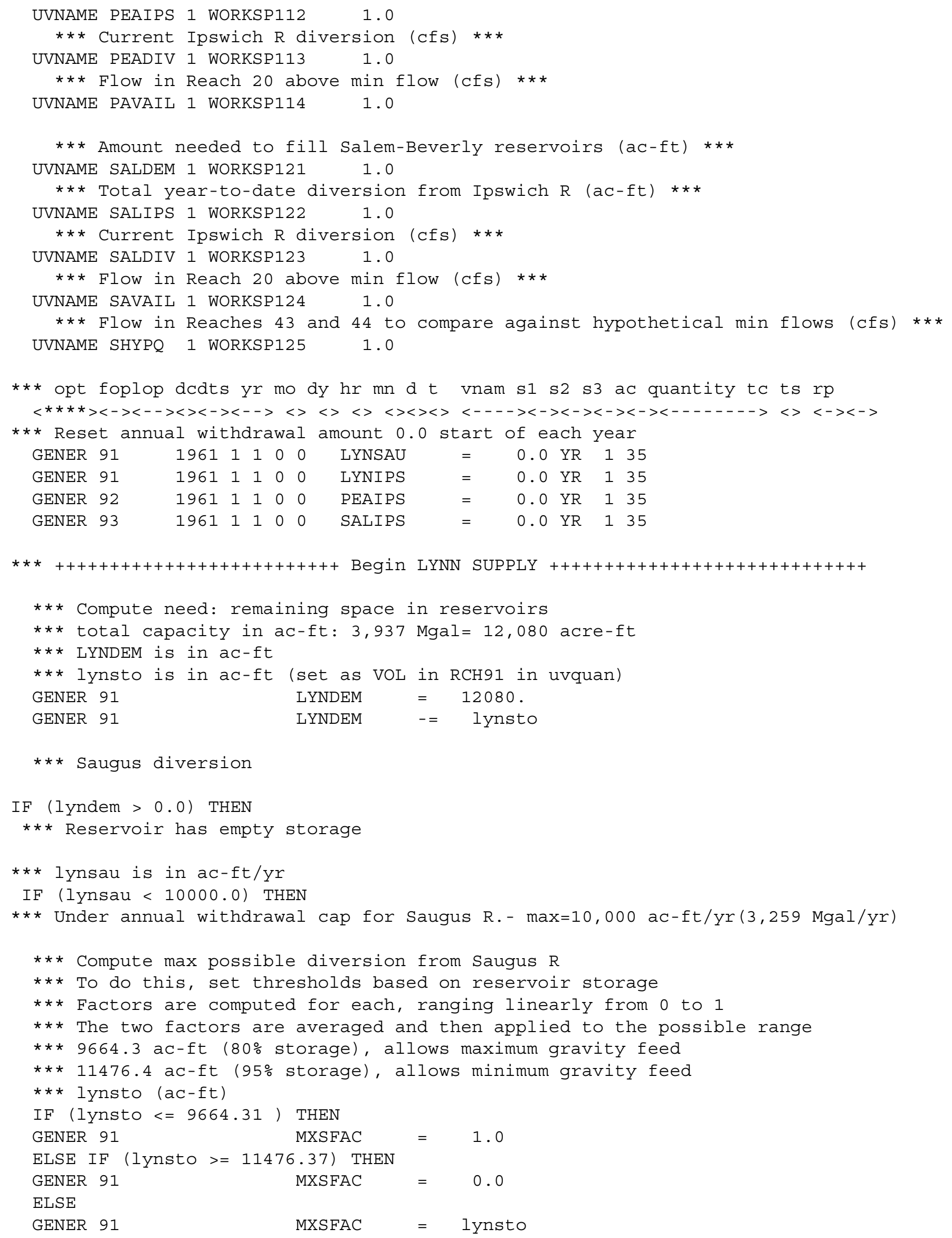




$\begin{array}{llccc}\text { GENER } & 91 & \text { MXSFAC } & -= & 9664.31 \\ \text { GENER } & 91 & \text { MXSFAC } & /= & -1812.06 \\ \text { GENER } 91 & \text { MXSFAC } & += & 1.0\end{array}$

END IF

*** Final factor used to compute actual diversion, limited to flow

*** lysdiv (ac-ft), Lower withdrawal limit $15 \mathrm{cfs}$, upper limit 26 cfs

$* * * 11 \mathrm{cfs}=0.90909 \mathrm{ac}-\mathrm{ft} / \mathrm{hr}$

$\star * * 15 \mathrm{Cfs}=1.24896 \mathrm{ac}-\mathrm{ft} / \mathrm{hr}$

GENER 91

GENER 91

LYSDIV $\quad=\operatorname{mxsfac}$

GENER 91

LYSDIV $\quad *=0.90909$

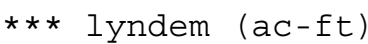

GENER 91 LYSDIV MIN lyndem

*** qsr_af is qsaugr converted to ac-ft/hr

GENER 91 LYSDIV MIN qsr_af

*** qsaugr is in Cfs, LYSDIV is in ac-ft

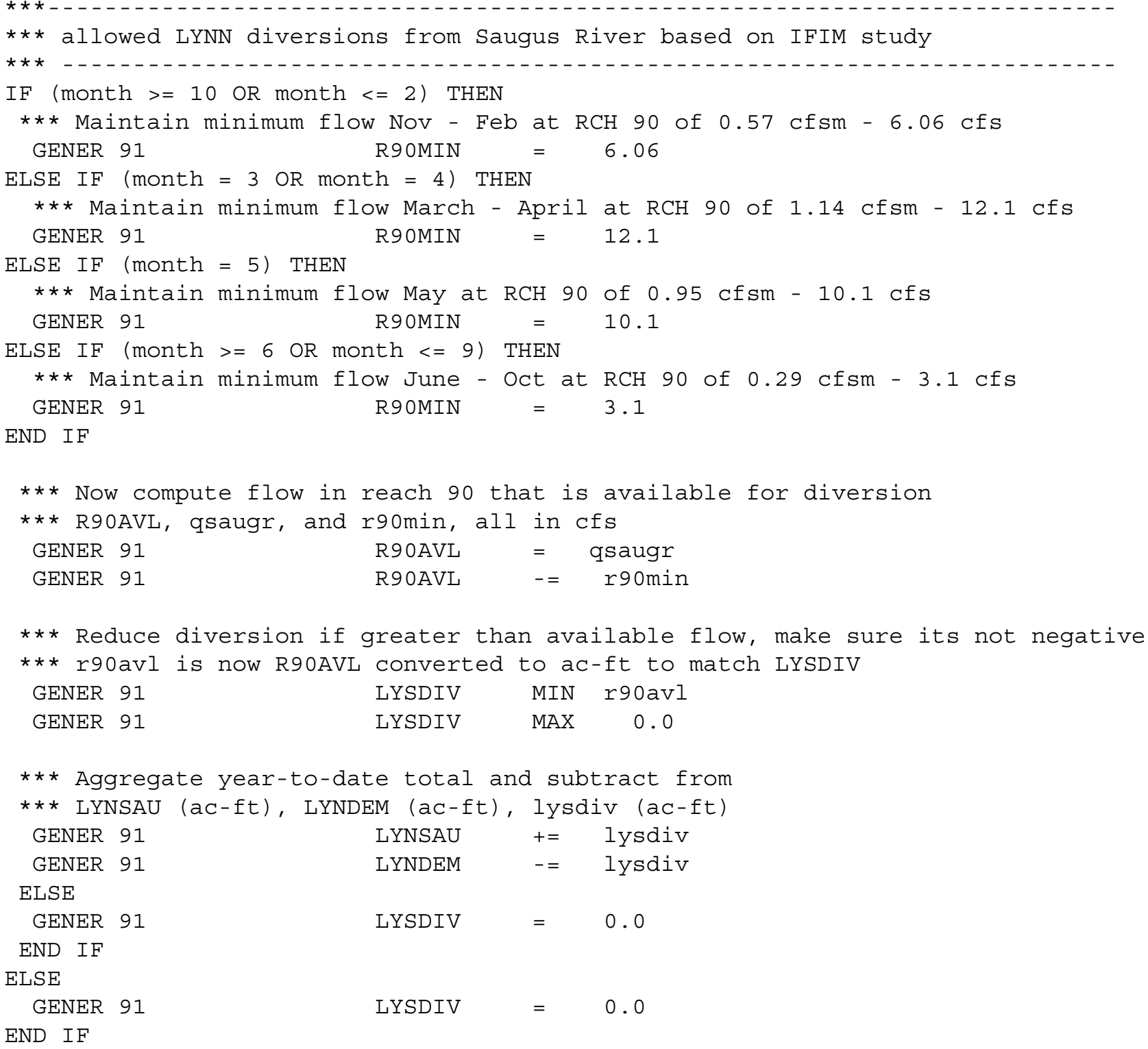




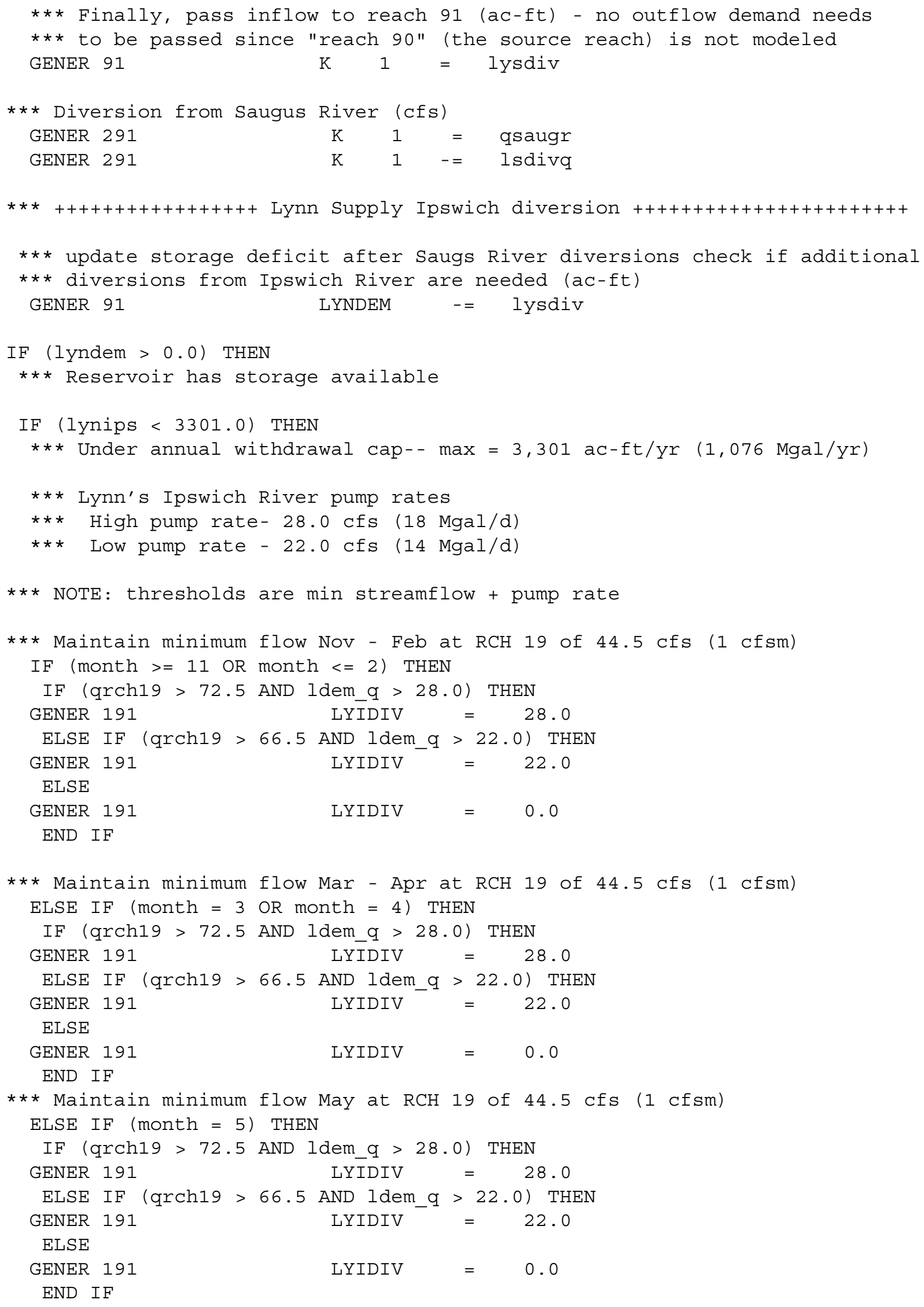




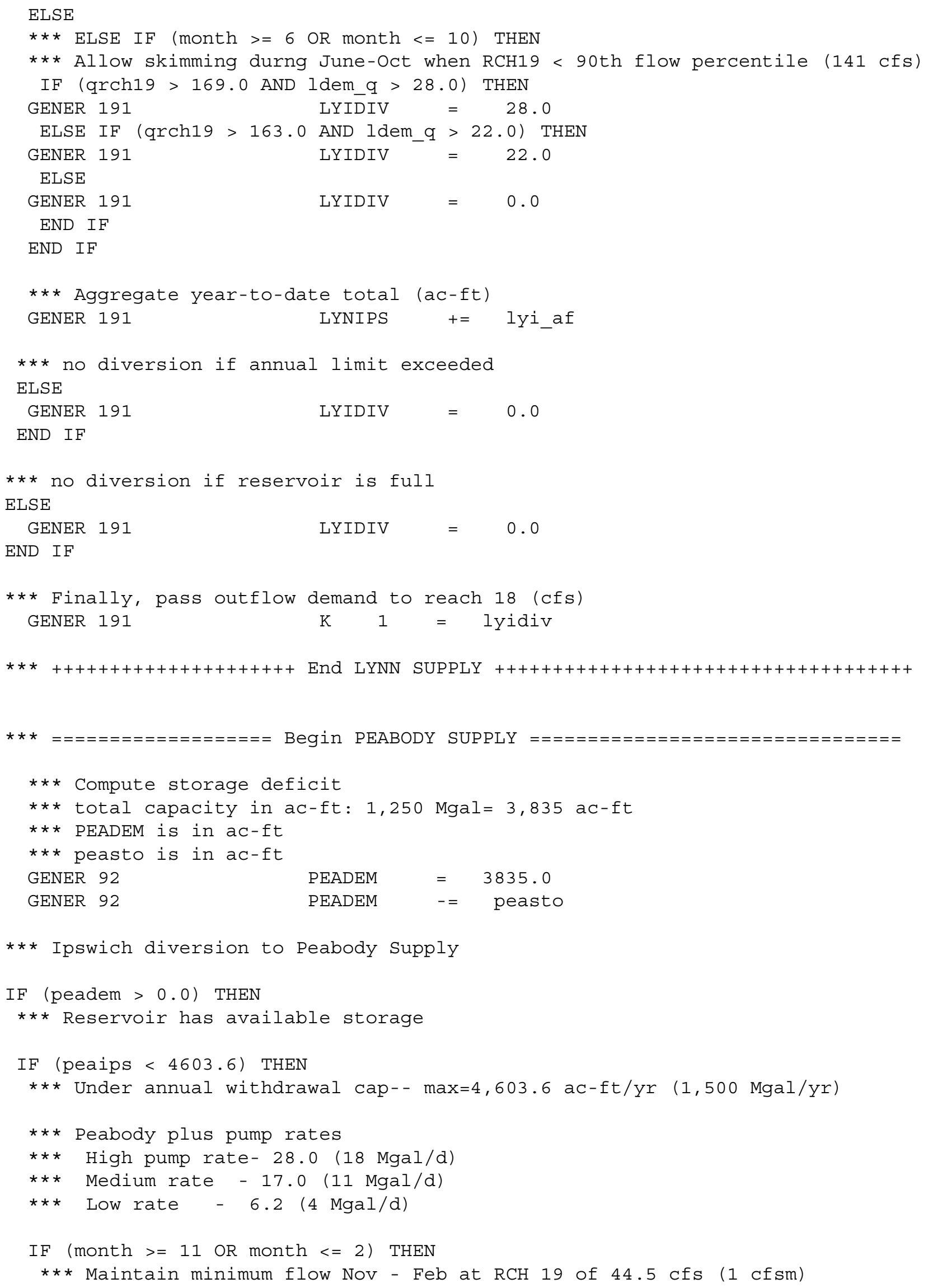




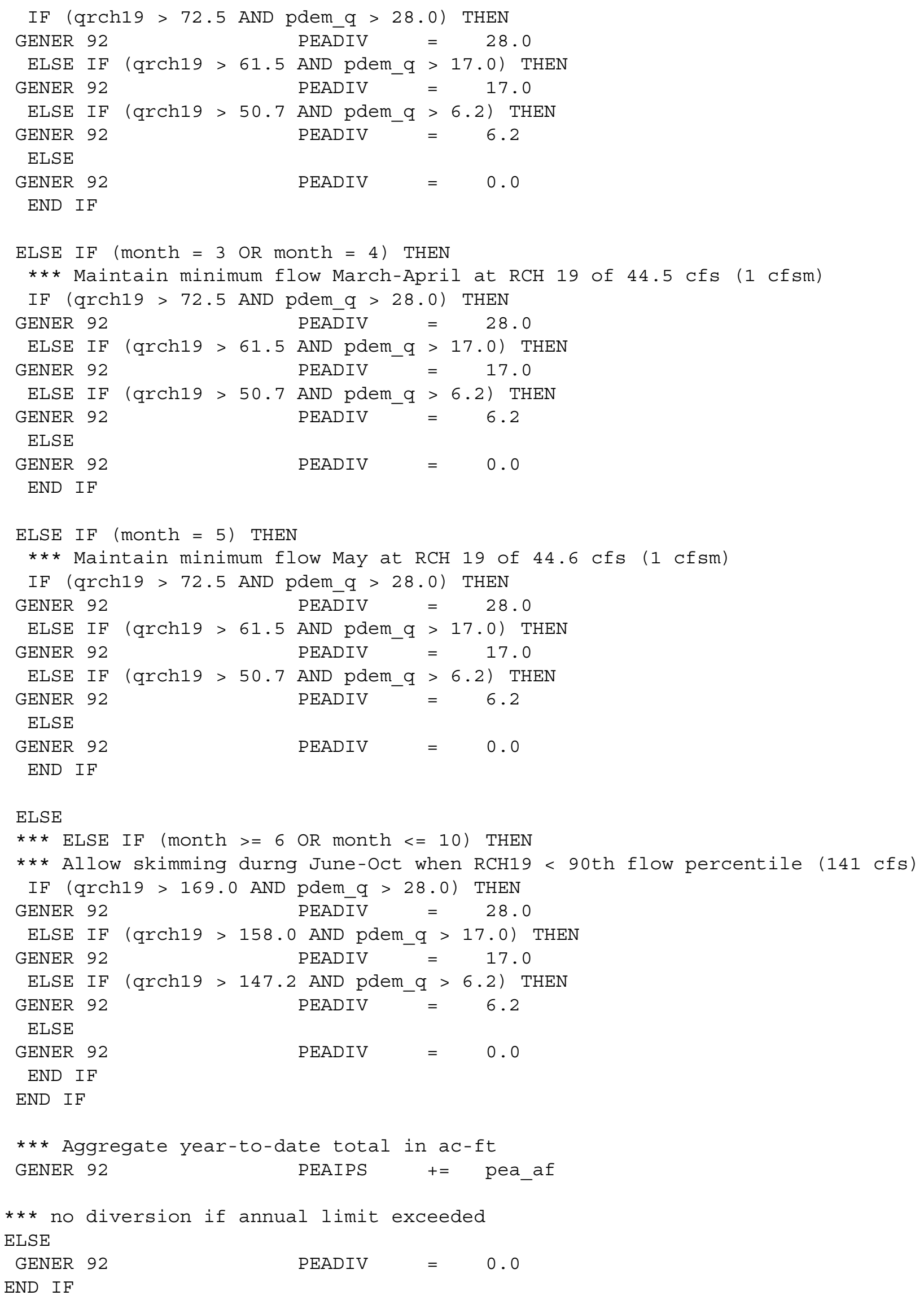




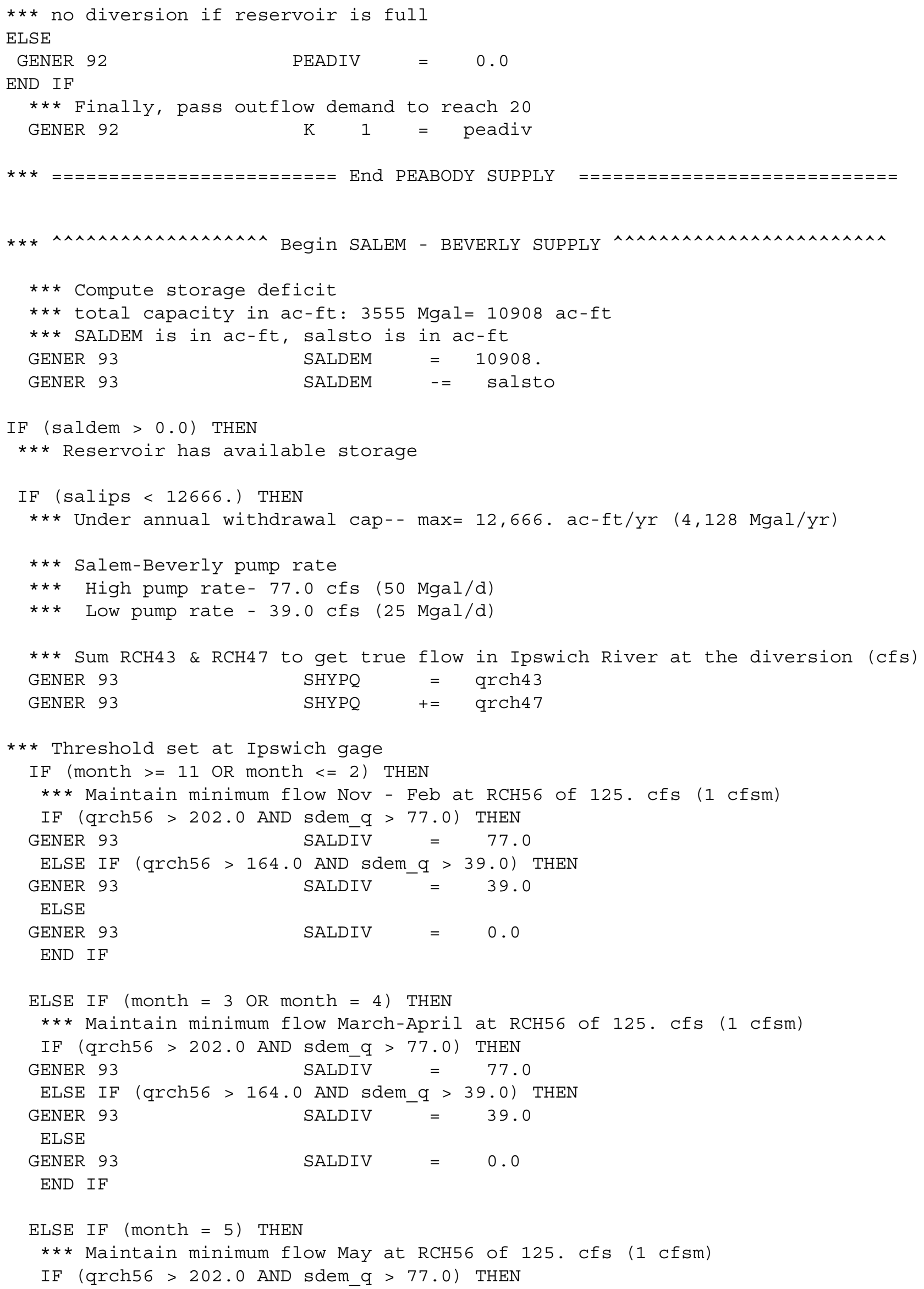




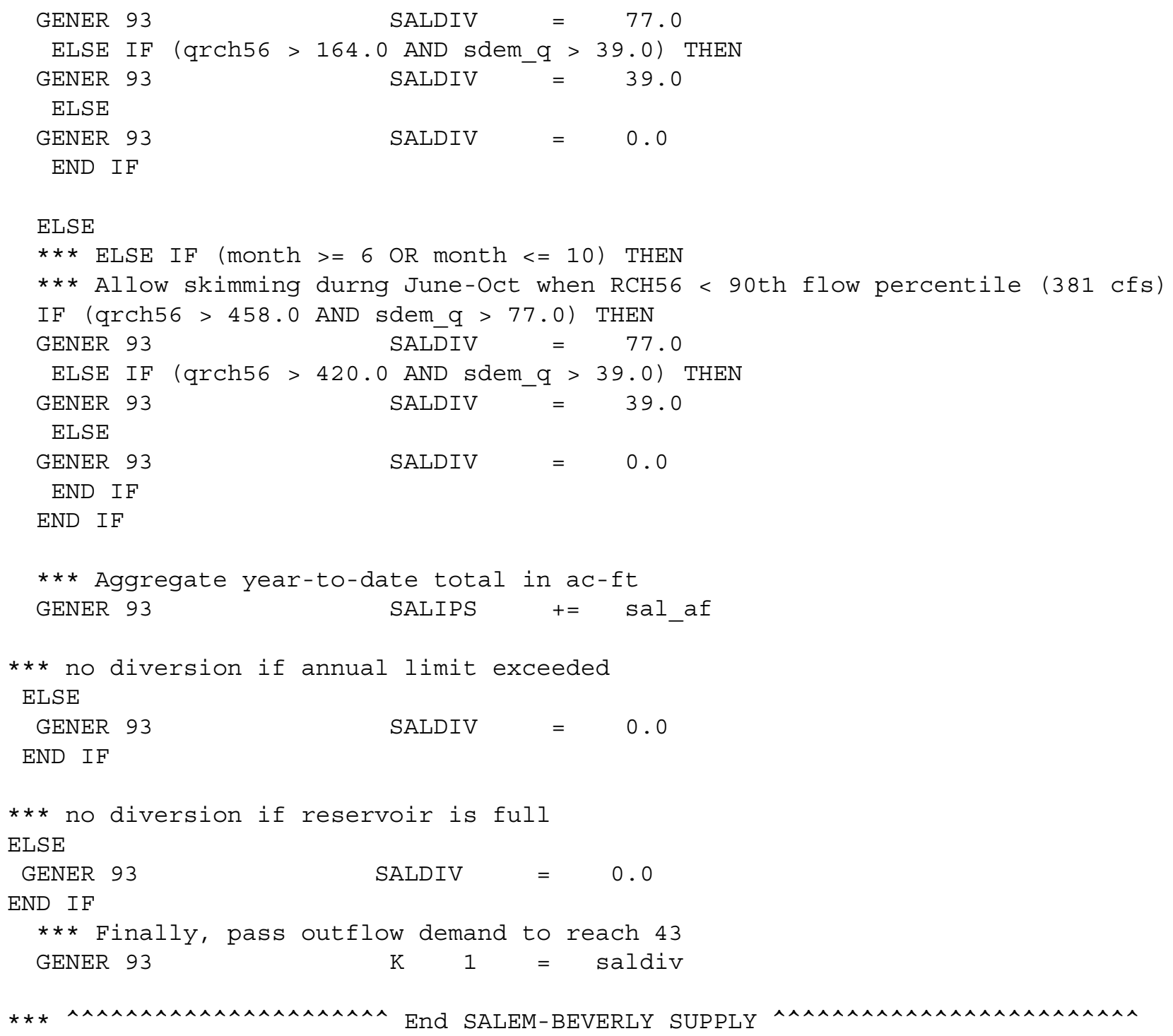


For additional information write to:

Chief, Massachusetts-Rhode Island District U.S. Geological Survey

10 Bearfoot Road

Northborough, MA 01532

or visit our Web site at

http://ma.water.usgs.gov 